\title{
Layers of the oldest Egyptian lexicon VIII: Numerals*
}

This paper belongs to a series of publications whose goal is to survey the most ancient part of Egyptian basic lexicon, classified by semantical domains, in order to stratify the different lexical layers (wherever they are present) in the light of Semitic vs. African Afro-Asiatic dichotomy, which was already suggested by P. Lacau several decades ago. The current paper focuses on the etymologies of Egyptian numerals.

Keywords: Ancient Egyptian, Afro-Asiatic languages, etymology, historical phonology, numerals.

In memoriam A. Zaborski (1942-2014)

\section{Introduction}

The first part of my series "Layers of the oldest Egyptian lexicon"1 re-examined the controversies of P. Lacau's (1970) old observation on a binary opposition of certain items of Ancient Egyptian anatomical terminology in the context of many new results issuing from current progress in Afro-Asiatic (Semito-Hamitic) comparative linguistics. The etymological examination of Ancient Egyptian anatomical terminology presented therein has corroborated a surprising distribution: one member of the synonymous pairs is usually a Semitic word, whereas the other one(s) has/ve non-Semitic cognate(s) solely attested in some of the African branches of our language macrofamily. A relatively deeper presence of the extra-Semitic vocabulary in Egyptian has also become apparent. The subsequent papers in this series ("Layers of the oldest Egyptian lexicon II-VII") focused on the rest of the Ancient Egyptian anatomical terminology, ${ }^{2}$ led by the wish to see to what degree this etymological dichotomy was characteristic there,

* It is here that I have to express my thanks to the Bolyai research fellowship (Hungarian Academy of Sciences, reg. no.: BO / 00360 / 12) facilitating my project on Egyptian linguogenesis, which resulted, inter alia, in a number of papers including this and the preceding parts of my series "Layers of the oldest Egyptian lexicon". I am pleased to express my gratitude to both Prof. W. G. E. Watson (Morpeth, UK) and Prof. G. Hudson (East Lansing, USA) for unselfishly devoting some of their precious time to correct the English of this text.

This paper is a farewell to my dear senior Semito-Hamiticist fellow, my unforgettable Doktor- and Habilitationsvater (ELTE, Hungary, June 1998 and October 2003, resp.), whose tragical premature passing away (autumn 2014) I cannot comprehend, to whom I owe so much. His famous studies on the Omotic and Cushitic numerals (1983 and 1987, resp.) are also considered here.

1 Takács, G.: Layers of the Oldest Egyptian Lexicon I. Rocznik Orientalistyczny 68/1 (2015), 85-139.

2 Part II deals with the Egyptian anatomical terminology for parts of the head and the neck, which is published in Rocznik Orientalistyczny 69/1 (2016), 59-124. Part III (with an etymological study on the upper torso) is planned to appear in Rocznik Orientalistyczny 69/2 (2016). Part IV (terms for the lower torso), V (parts of the foot), VI (back parts of the body and below), and VII (terms pertaining to the body in general, e.g., skin, flesh, blood etc.) are still being prepared, but not yet ready for publication, although the relevant raw lexical materials have already been accumulated and so certain preliminary impressions are already available. 
with the outcome that the overwhelming majority of Egyptian body part names was merely South Afro-Asiatic.

Now, as in my previous communications, the Egyptian numerals, as part of the basic vocabulary, are examined from the same standpoint so that we can see these diverse (South vs. North Afro-Asiatic) layers of our numeralia. May this paper express my high esteem and affection for our great Master in comparative Afro-Asiatic (Semito-Hamitic) studies, whose department at the Jagellonian University of Kraków was the only one in the world devoted to Afro-Asiatic linguistics in the recent decades.

Eg. VwS "eins" (OK-, Wb I 273-276): in spite of the many unsuccesful attempts at its AfroAsiatic etymology made over the past one and a half of a century, ${ }^{3}$ only recently has $\mathrm{W}$. Vycichl (DELC 518), followed by A. Ju. Militarev (in Starostin et al. 1995, 23), found its phonologically completely satisfactory cognates, which only appear in Semitic, where the latter scholar reconstructed the underlying root as * $\sqrt{w}_{\mathrm{f}} \mathrm{y}$ "to sweep together", cf. OT Hbr. $\sqrt{y}$ 个y qal (hapax, Is. 28:17) “wegraffen”, hence yā९̄̄m (pl.) "Schaufeln" [GB 306-7] = لy yy "to sweep away (hail)", hence *yāৎ or *yāSe(h) "shovel to clean the altar" [KB 419] = ل y Sy "to sweep toegther and carry away" [Klein 1987, 261a] | OSA Vy yy "to snatch away" [Müller quoted in KB], Ar. $\sqrt{w}\{y$ I: wa§ā "1. rassembler, ramasser, réunir sur un seul point, 5. s'amasser sur un seul point (se dit, p.ex., du pus dans la plaie), 6. être guéri (se dit d'un os fracturé dont les éclats se réunissent)" [BK II 1570] = "sammeln" [GB] = "to collect, hold" [KB] = "umfassen, enthalten" [Lsl.]. Besides, it is this root that, following F. Rundgren (1961, 121-127) and W. Leslau (1987, 23), also the Semitic term for "Eingeweide" (usually taken from $* \sqrt{\mathrm{m} \uparrow \mathrm{y}}$ ), is derived from an assumed primary stem **mißw§ay- "(etwa) Sammlungsort, Gefäß”.

Eg. Vsn (hence masc. dual sn.wj, fem. sn.tj) "zwei” (OK-, Wb IV 148) is identical with Sem. *tin- "2" [Djk.] = *歽y [Vcl.] ||| Brb. * $\sin$ "2" [Mlt. 1991, 167]," i.e., this numeral root is only at-

${ }^{3}$ The most widespread etymology was its combination with Ar. Vwḥd and its Semitic kindred, cf. Sethe 1916, 21, §1; Ember 1917, 87, \#134; 1926, 305, \#3.4; Albright 1918, 90; 1927, 200; Behnk 1927, 81, \#7; ESS §5.c; Dolgopol’skij 1967, 300, \#5; Schenkel 1997, 114. In addition to this Eg.-Sem. comparison, which was rightly declined already by V. Blažek (1999, 30, §4.1), several scholars, e.g., L. Reinisch (1874, xii, fn. 3), F. Behnk (1928, 139, \#18), E. Zyhlarz (1931, 134-135; 1950, 407), Ju. Zavadovskij (1967, 43; 1974, 105; 1975, 45), and then E. Lipiński (1997, 284, §35.3.e) suggested further cognates in NBrb. yen (m), yẹt (f) and SBrb. iyen (m), iyet (f) “1” [Zhl.] derived by E. Zyhlarz from * $\sqrt{w g y}_{\text {gg }}(1931)$ and later even from an artificial $* \sqrt{W}_{\mathrm{w}} \hat{\text { y }}(1950)$ or most surprisingly by E. Lipiński (l.c.) from a *wa§(-n). V. Blažek (1987 MS, §1.2; 1990, 34; 1999, 30, §4.1), in turn, identified both Sem. * ${ }_{\text {w }}$ y and Eg. wS (in 1990, strangely, only Eg. wS) with the Berber numeral for "1", whose Proto-Berber etymon has been recently reconstructed as *yīw-ān/-at [Prs.] = *ya-N/T [Zvd.] = *iyyaw-an/at (m/f) [Mlt.]. L. Homburger (1928, 335 along with many other untenable non-AA parallels) and H. Abel $(1933-34,305)$ connected Eg. wS to Common Nubian *wēr “1”. Similarly, W. Leslau (1962, 47, \#27, cf. Conti 1978, 43, fn. 5) assumed a relationship with ES: Tigre woro “1”. Both suggestions suffer from the fact that the correspondence of $r$ to Eg. $\uparrow$ is irregular. M. L. Bender (1975, 179), in turn, affiliated the Eg. numeral with SCu.: WRift *wak- "1" [GT pace Zbr. 1987, 343], in which, however, there is no trace of the * . In addition, as Ch. Ehret $(1980,312)$ pointed out, the WRift term is "probably" juxtaposed from two demonstrative roots ( $\left.{ }^{*} \mathrm{wa}+{ }^{*} \mathrm{ka}\right)$, which is certainly not the case of Eg. wS. V. Blažek (1990, 34; 1993 MS, 3, §1.9) too, beside the Berber parallels (above), could not resist comparing SCu.: Ma'a (Mbugu) wé “1” [Green, Wtl.] and WCh.: Karekare wàiké "each, all" [Krf.], where he singled out an "element" *wV "1".

4 See Hommel 1883, 96, §11; Erman 1892, 118; Sethe 1916, 19, §2; Albright 1918, 91; 1926, 189; 1923, 68; 1927, 200; Ember 1926, 305, n. 7; Farina 1926, 15; Behnk 1928, 140, \#44; ESS §11.a.50; Zyhlarz 1931, 135, §2; Vycichl 1955, 310; 1958, 378, 399; 1974, 62, §5; D’jakonov 1965, 46; 1974, 742; 1986, 61; Hodge 1968, 27, \#113; 1981, 410; 1990, 646, §9.A; Zavadovskij 1967, 43; 1974, 106, §6.1; 1975, 45-46; Dolgopol'skij 1973, 111; Bender 1975, 194; Belova 1989, 14; Militarev \& Stolbova 1990, 56; Militarev 1991, 75; Dombrowski \& Dombrowski 1991, 343; Lipiński 1997, 284, §35.4; Blažek 1999, 30-31, §4.2. 
tested in the northern branches of the Afro-Asiatic macrofamily of languages. Elsewhere, it is unattested with *-n. The Semitic root has, however, also a heteroclitic variety with *-r, which may be traced back even on the Proto-Afro-Asiatic level, cf. AA *čir- *čar- "two" [GT] > Sem. **tir- > *tor- "two" [GT] ${ }^{5}|| \mid$ presumably SCu.: WRift *čar- (unless < *čad-) "two" [GT] ${ }^{6}||$ PCh. * V̌̌r "two" [GT].7 The Sem.-SCu.-Ch. etymology was first suggested by V. Blažek (1987 MS, 8-9, \#2.2;

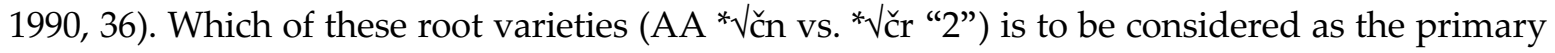
one is not to be answered here. It is, however, noteworthy that only Semitic has both of them.

Eg. Vhmt (hence occuring as masc. pl. hmt.w, fem. hmt.t) "drei" (OK-, Wb III 283): the mystery of its origins has sometimes led to sometimes to absurd etymologies. ${ }^{8}$ In his prestigious L $\ddot{A}$ article on Egyptian numerals, A. Loprieno $(1986,1308)$, however, all too hastingly and carelessly remarked that "eine überzeugende Etymologie liegt nicht vor", which was by far not true even in his day. Surprisingly, he overlooked and did not even quote the most hopeful approach suggested at that time by a number of outstanding comparatist authors like A. Trombetti (1902, 196, §3), C. Meinhof (1912, 233), and M. L. Bender (1975, 192), who all combined the Egyptian numeral with NOm.: Kafa kämō "3" [Rn. 1888, 56] = kếmō [Mnh.] = kēmō [Crl. 1951, 461] = keymo [Bnd. 1971, 259], a numeral apparently standing totally isolated within Omotic. Whether the similarly isolated WCh.: Karekare kumu (sic, -m-) “3” [IL apud JI 1994 II $326]^{9}$ is, in fact, also cognate, is hard to determine as elsewhere in the West Chadic daughter

${ }^{5}$ Attested in Biblical Aram. tərēn, fem. tartēn [GB 931], Mandean tartin atrin [Drower], Neo-Aram. ițr(i), fem. tare(i) [Bergsträsser], Neo-Syriac trī tīrti tirwē tarwē [Kutscher] (NWSem.: KB 2009) || MSA: Soqotri tro (tiro) (poetical) tróho (so, t-) [Lsl. 1938, 445] = tro, fem. trih [Jns.], Harsusi terō, fem. terét [Jns. 1977, 133], Jibbali troh, fem. țrut [Jns. 1981, 285], Mehri tru (tru), fem. țrīt [Jahn] = torō trroh, fem. oțráyt $\sim$ trrelt [Jns. 1987, 418].

${ }^{6}$ Based on the equation of Iraqw tsar and Burunge čada (WRift: Ehret 1980, 229, \#4).

${ }^{7}$ Attested in WCh.: NBauchi *čir *čar [GT], cf. Jimbin šír [Skn.], Pa’a čírù [MSkn.] = čiřu [IL], Siri bi-čáre (ch-) [Gowers] = bə̄-čâr [Skn.] = bù-čárì [IL] (prefix bV- of numerals), Miya cîr (ts-) [Skn.], Mburku cər (ts-) [Skn.] (NBch.: Skinner 1977, 33) | Bade sērīn [IL], Ngizim šírín [Schuh] = šírin [IL] || CCh.: Musgoy sray [Mch.], Daba sraj [Pascal] = sìrāy [Lienhard], Kola sàrây [Schubert] || ECh.: Sumray sór [Jng.], Tumak heغ̀ [Caprile], probably < *sēr [GT] | WDangla sèc̀r, sèc̀ró [Fédry], Migama sê:rà [Jng.], Mokilko sìré [Jng.] | Mubi-Toram *sīr(i) [GT] > Mubi sìrr [Lks. 1937, 185] = *sìr [Bnd.-Drn. 1983, 78, \#90] = sìr [Jng. 1990 MS, 42], Birgit síirì [Jng. 2004, 358], Minjile *sir [Bnd.-Drn. 1983, 78, \#90], Kajakse *siri [Bnd.-Drn. 1983, 78, \#90], Masmaje sìrrì [Alio 2004, 284, \#151], Toram see [Alio 2004, 262, \#397], Jegu šee [Jng. 1961, 117], Kofa sèy [Jng. 1977 MS, 16, \#402].

${ }^{8}$ W. M. Müller 1907, 303, fn. 1; Sethe 1916, 21, §3; Albright 1918, 91; 1927, 199; Farina 1926, 14; ESS §10.a.33:

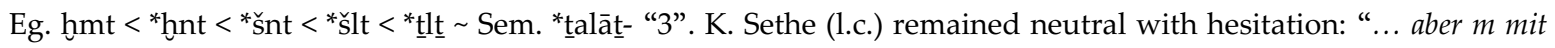
sem. 1, t mit $\underline{\mathrm{t}} z$ u identifizieren, fehlt mir vorläufig doch der Mut”. M. M. Bravmann $(1933,148-149)$ assumed Eg. hmt < *hlt $<$ *flt $<$ *tlt allowing even that "there is no problem with $m<*$ in Egyptian" without further evidence. Even W. Westendorf (1962, 27, fn. 1) mentioned the alleged cognacy of Eg. hmt vs. Sem. *talāt- among the instances of the interchange of Eg. m n (sic). A. Ember (1917, 88, fn. 1), in turn, was “inclined to believe” in its cognacy with Sem. * $\sqrt{\text { hmmš } ~ “ 5 ” . ~ K . ~ S e t h e ~}(1916,23$, fn. 2), following this idea, assumed that there "war bei der Trennung der beiden Sprachzweige noch ein unbestimmter Vielheitsausdruck, den der erste Zweig dann für das eine, der andere für das andere absterbende Zahlwort einsetzte, which A. Loprieno (1986, 1315-1316, n. 18) rightly doubted: "vermag ich weder phonologisch noch semantisch zu verstehen”. L. Homburger's $(1928,336)$ African parallels (outside AA, such as, e.g., Bantu satu, Agni nsâ) are evidently out of the question equally for phonetic reasons. Ju.N. Zavadovskij (1967, 43; 1974, 107, §7; 1975, 47, §7.0) put forward his strange idea that Brb. $\sqrt{ } \mathrm{krd}$ “ “3” “соответствует до некоторой степени” tо Eg. hmt (1967 1.с.: “параллелизм здесь выражен цепочкой 'гортанный + сонант + зубной”; 1974 1.c.: both roots are of parallel structure: post-palatal + sonant + dental), which V. Blažek $(1999,63, \S 3.1)$ has already correctly rejected as it "does not respect any known phonetic law".

${ }^{9}$ Note that J. Lukas $(1966,202)$ recorded Karekare kúúnù (sic, with -n-), which is, contrary to the record made by the IL with the unexpected anomalous -m-, in accordance with the rest of the comparative evidence usually gained from West Chadic. 
language groups (Angas-Sura, Ron, Bole-Tangale), there seems to emerge a proto-form *kun“3" [GT] = *kunu [Stl. 1987, 209, \#595]. ${ }^{10}$ But where is the trace of a dental plosive $C_{3}$ in Kafa and Karekare? Nowhere, in fact. This lack of the third radical makes me doubt this EgyptoChatic comparison and search further.

The West Chadic biradical root was handled, e.g., by H. Jungraithmayr and D. Ibriszimow (1994 I 168A) as a remnant of their triradical PCh. * $\sqrt{\mathrm{knd}}$ " 3 ” via apocopy. Interestingly and astonishingly, this is precisely the very same sequence of those root consonants that Eg. $\sqrt{ } \mathrm{hm} t$ also represents, i.e., velar + nasal + dental! All three radicals of this Proto-Chadic triradical root have been preserved until now, with the necessary Lautverschiebungen, of course, by the following daughter languages: WCh.: Jimbin kōndí [Skn.], Diri hyíinzù [IL] = hìnzù [Skn.] < *kind- [GT] || CCh.: PMasa *hindi, regular < *Kindi "three" [GT]: Banana yìntì(di) [Krf.] = yìnti [Zima], Musey hindi [Krf.], Gizey/Wina, Ham, Musey, Lew, Marba hìndì [Ajl. et al. 2001, 56], Lame hinzi [Lks. 1937, 139] = hínčìi [Krf.] = hínzìì̀ [Scn. 1982, 516], Zime-Batna hídì [Jng.] = híndzìì [Scn.], Peve hínžī [Krf.], Zime-Dari hinyi < *hinži < *hindi [Str.] = hinyi [Lks. 1937, 139] = hinži? [Venberg 1975, 41], Zime-Misme hindi [Krf.] (Masa group: Zima 1990, 268; Ch. data: JI 1994 II 326-7). In the light of these data, the reconstruction of PCh. * $\sqrt{\mathrm{knd}}$ " 3 " [JI] might be modified on two points. First, the correspondence of k- in the majority of the Chadic daughter languages to h- in the Masa group speaks for a PCh. fricative *h- (cf. Stolbova 1996, 68, §I.6, table 6) and not a plosive *k-. Secondly, the glottalized * ${ }^{*}$ is not really supported by any of the reflexes listed above, where we mostly find either plain $-d$ or its palatalized sequence $(-\check{z}>-y)$, which is not at all a typical phenomenon with a glottalized dental plosive and evidently indicates *-d. All in all, if the cognacy between PCh. * $\sqrt{h}$ nd $\| \mid$ Eg. $\sqrt{h m t}$ "3" is true, it is to be explained by the circumstance that the cluster $-\mathrm{C}_{2} \mathrm{C}_{3}$ - of $\mathrm{PCh}$. ${ }^{*}$ hind- resulted from a voicing process (influenced by $\left.{ }^{*}-\mathrm{n}-\right)^{11}$ and an assimilation ultimately from **himt- [GT]. To the best of my knowledge, so far nobody (not even V. Blažek in his exhaustive 1999 book on the numerals in Afro-Asiatic and Indo-European) has suggested this Ch.-Eg. comparison.

In a number of Chadic reflexes of this (?) root, the medial nasal radical is not reflected, only a velar $C_{1}\left({ }^{*} k-\right)$ and a dental $C_{2}$ (possibly ${ }^{*}$-d), i.e. ${ }^{*} \sqrt{ } \mathrm{kd}$ or sim. ${ }^{12}$ These Chadic forms may be akin to ECu.: Yaaku hāt "3" [Heine quoted by Zbr. 1987, 342], regularly derivable from a hypothetical ECu. ${ }^{* *}$ kād- [GT], which is completely isolated within the whole Cushitic family. Does the underlying etymon, in fact, represent the ultimate biconsonantal root? In addition, H. G. Mukarovsky $(1987,35)$ combined these reflexes with NOm. ${ }^{*} \sqrt{k d} / \mathrm{z}$ "3" [Mkr.] = * ${ }_{h} 3$ [Zima] $={ }^{*}$ Kazu $>{ }^{*}$ Kawz- $>{ }^{*}$ Kay ̌̌- $\left[\right.$ Blz. 1990, 39] < ${ }^{*}$ hayd- $[\mathrm{GT}],{ }^{13}$ which only confirms the sup-

${ }^{10}$ O. V. Stolbova (l.c.) was unaware of the Tal and Goemay data, which betray a glottalized *k- instead of plain *k-.

11 The same voicing effect of the nasal has been observed in the cluster -nC- throughout the whole Egyptian Sprachgeschichte, cf. the shift of Cpt. (S) nc > nz attested in Eg. S.t-n.(t)-sb? "school" > (SF) ancybe, (SL) ancyb, (S) anZybe, (B) anZyb, etc. (KHW 8); cf. already the OEg. alphabetic writing nzw for nsw "king", which was certainly vocalized as * $\mathrm{j} /$ /insiw with a cluster *-ns- as cuneiform evidence from the 13th century BC also indicates (Wb II 3259; Sethe 1911, 16-30; 1912, 98; Farina 1926, 16; ÜKAPT IV 54, ad PT 814c; A ̈̈G 51-52, §116).

${ }^{12}$ Cf. WCh.: (?) Bokkos Rátát [Jng.] < *had- (?) [GT] | Warji kážì [Jng. and Skn.] = kª́żì (-dz-) [IL], Tsagu kádá [Skn.], Kariya and Miya kấdì [Skn.], Pa'a kádù [Jng. \& MSkn.] = kədu [IL], Siri bu-kudde [Gowers] = bù-kúdì [IL] = bu-kúdi [Skn.], Mburku kídí [Skn.] || CCh.: Mandara kóžọ [Mch.] = kiß̌̌e [Meek] = kíß̌̌é [Eguchi] <*ki[r]de (?) [GT] | Masa hidi [Mch. 1950, 59, so also Krf.] = hìdir [Jng.] = [hìdī] ${ }^{12}$ [Ctc. 1983, 88] = hìdí "trois" [Ajl.], Masa-Bongor hìdī? “trois” [Jng. 1973 MS] || CCh.: Mandara kəḍye [Wolff 1974, 16] || ECh.: (???) Mokilko Ráḍó (perhaps < *haḍ-, cf. kádùwé “zum dritten Mal”) [Lks.] (Ch. data: JI 1994 II 326-7).

${ }^{13}$ Cf. NWOmeto *hayz- [GT]: Welamo hezzā [Moreno] = hĕza [Bnd. 1971, 252] = esa, eza, heza [Chiomio 1938, 4; Da Trento 1941, 206], Gofa heza (-dz-) [Moreno], Zala hezzā [Moreno], Malo héza [Moreno], Kullo hezu [Allan 
position of an ancient biliteral root. If this latter scenario is true, we would have to assume a PAA * $\sqrt{\text { hd }}[\mathrm{GT}]$, which, however, contradicts the development of PCh. ${ }^{*}$ hind $-<{ }^{* *}$ hint- < **himt- [GT] outlined above and possibly also the equation with Eg. $\sqrt{ } \mathrm{hm} t$.

It is very probable that CCh.: PDaba *makad "3" [GT] ${ }^{14}$ represents merely the same biconsonantal root $(* \sqrt{\mathrm{kd}}$ or sim.) extended by an $\mathrm{m}$ - prefix instead of being the reflex of a hypothetical AA * $\sqrt{\mathrm{mhT}}$, i.e., the metathetic cognate of Eg. $\sqrt{\mathrm{hm} t}$ " 3 ", however tempting this may seem prima vista.

Eg. Vhmt "3" was identified by C. Meinhof $(1907,123 ; 1912,233),{ }^{15}$ E. Zyhlarz $(1931,135-$ 136, §3), W. Vycichl (1959, 33), H. G. Mukarovsky (1987, 45), and V. Blažek (1987 MS, 14-15, $\S 3.1 ; 1990,38 ; 1993$ MS, 5, §3.1; 1999, 32, §3) $)^{16}$ with the Bed. numeral “3”, which was apparently

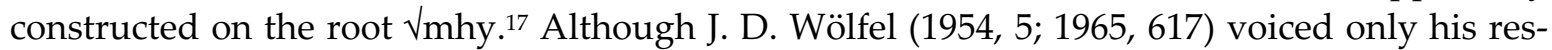
ervations against this Eg.-Bed. comparison and in A. Zaborski's $(1987,319)$ view too, "this is phonologically rather improbable", one is tempted to ponder whether Zyhlarz (l.c. supra) was correct, having ingeniously envisaged a PBed. *măhádi (or sim.) on the basis of the supposed shift of Bed. y from an earlier palatalized dental, which is in fact valid for Bed. $y=E C u$. ${ }^{*} \mathrm{z}$, cf. Bed. hayúk "Stern" [Rn. 1895, 133] || LECu.: Somali haḍig [Rn.] = hiddig [Sasse] = hadig [Zhl.] < ECu. *hizk-/*huzk- "star" [Sasse 1979, 35 etc.]. Following this scenario, one might be inclined to surmise in both PBed. *mahadi "3" [Zhl.] and CCh.: PDaba *makad "3" [GT] (above) the same $\mathrm{m}$ - prefix extension of the same root. On the other hand, it is equally inspiring to observe - together with H. G. Mukarovsky $(1987,45)$ - the closeness of Bed. Vmhy to WCh.: SBauchi * $\sqrt{\mathrm{mKy}}$ (perhaps ${ }^{*} \mathrm{~m}^{(\mathrm{w})} \mathrm{a}[\mathrm{h}] \mathrm{ay}$ ?) "3" [GT], 18 since the latter can by no means be explained from *ma-had (or sim.) the same way as in Bedawye, and - even more interestingly - the common

1976, 330] = hēza [Bnd. 1971, 252], Dache heza (-dz-) [Bnd. 1971, 253], Dorze hēza (-dz-) [Bnd. 1971, 253] = heiza [Flm.], Male hāyco (-yts-) [Da Trento 1941, 206; Bnd. 1971, 255], Oyda hāyzi (-dz-), oyddi [Bnd. 1971, 254] (NWOmeto: Moreno 1938, 37) | SEOmeto *hay3- [GT]: Zayse hayc (-ts) [Crl. 1938 III, 194], Zergulla hayc (-ts) [Bnd. 1971, 257], Gidicho hāyzi (-dz-) [Bnd. 1971, 256], Koyra hayze (-dz-) [Hayward, also Bnd. 1971, 252], Mezo hayzi (-dz-) [Chiomio 1938, 235], Basketo hayzzā [Crl. 1938, 108] = hay/d/zi [Bnd. 1971, 254], Doko oyzē [CR 1927, 248] = hāyzā [d'Abbadie apud CR 1.c.], Dollo ayz [CR 1927, 250] | Dizoid *kad(d)u [GT]: Dizi kadu [Toselli 1938, 13] = kàdú [Allan 1976, 381] = kaddu [Crl. 1951, 309], Sheko kaddu [CR 1925] = kādu [Bnd. 1971, 262] = kādem [Crl. 1951, 309], Nao kaddu [CR 1925] = kādu, kaddŏ [Bnd. 1971, 262] | Janjero kēz [Crl. 1938 III, 57] | Chara kezā [Crl. 1938 III, 151] | Gimirra kazu [Toselli 1939, 35], She kaz [CR 1925], Bencho kəz [Bnd. 1971, 260] | Kefoid (or Gonga) *kě̌ž-

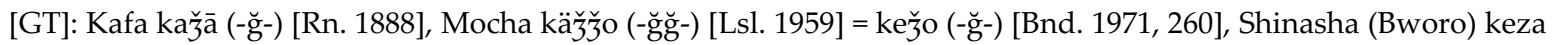
[Schuver in Grottanelli 1940, 103] = ke' ̌̌a (-'̆ğ-) [Grottanelli 1941, 266] = kēze [Brauner 1950, 70] = kēzza [Bnd. 1971, 259], Anfillo kě̌žo (-ğğğ) [Grottanelli 1940, 103] = kē'̌̌o (-'dj-) [Bnd. 1971, 258] (NOm. Data: Zbr. 1983, 384-387). Note that V. Blažek $(1990,39)$ erroneously explained the NOm. stem from his AA * $3 a K u$ "3" via metathesis based on his comparison with Agaw *seqw $/ \gamma^{\text {wa }}$ "3", PIraqw *dakati "8", WCh.: Hausa takwas "8", CCh. *tVkwazV "8".

${ }_{14}^{14}$ Attested as Musgoy makat [Mch. 1950, 59] = makaa (sic) [Str.], Daba makat [Mch. 1966, 133] = maakaa (sic) [Str.] = màkāạ [Lienhard], Hina maakáá (sic) [Str.], Kola màkâd [Schubert] (CCh.: Str. 1910, 456).

${ }^{15}$ In his paper from 1912 he meant this comparison beside the Kafa root $\sqrt{ } \mathrm{km}$ for " 3 ".

${ }^{16}$ Zyhlarz equated at the same time the Eg. numeral also with the Guanche term for "3".

${ }^{17}$ Recorded as (Bisharin) mehéy $\sim$ máhi $\sim$ maháy [Almkvist 1885, 46] $=$ (Hadendoa, Halenga, Bisharin) emhá/áy meháy maháy seldom mẹhá/áy [Rn. 1894, 10; 1895, 18, 167] = məhéy [Roper 1928] = mhay [Bnd.] = (Arteiga) mhày miháy [Hudson] = (Hala/enga) maháy [Rn.] = (Ammar’ar) mhäyy-t (f) vs. mhäyy-b (m) [Dlg.] (Bed. data: Dlg. 1973, 319; Zbr. 1987, 328; 1989, 589, \#85).

${ }^{18}$ Attested in Boghom mói mòi [Jng.] = mwày [Smz.], Zangwal maya [Smz.], Wangday mà·kí [IL] = mà:kai [Smz.], Zaranda maaki [Smz.], Dokshi màà $i$ [Smz.], Dikshi and Bandas mààgi [Smz.], Boodli (Zumbul) mààya [Smz.], Zodi (Dwa/ot) mààgai, Zakshi mààgi [Smz.], Boot, Zaari, Sigidi mààki [Smz.], Zaar mái [IL] = mà:yi [Smz.], Zaar of Kal mààyi [Smz.], Zaar of Gambar Leere màài [Smz.], Zaar of Lusa maayì [Smz.], Tala mee [Smz.], Sho (Ju) miyaa [Smz.] (SBauchi data: Shimizu 1978, 39, \#76). 
biradical root $*$ hyy that might in principle be singled out by assuming an $\mathrm{m}$ - prefix here, also finds a surprising match in the southernmost extremity of Cushitic, namely SCu.: Ma'a kaí haí "3" [Ehret], which is similarly attested with a prefix mi- (this, in turn, being from Bantu), cf. Ma'a mi-hai “3” [Mnh. 1906, 314]. As for the Southern Cushitic background of the Ma'a numeral, Ch. Ehret (1980, 249, \#C2) suggests a comparison with Dahalo kára “3”. The loss of final consonants is indeed an attested feature of Ma'a Lautgeschichte. The problem is, however, that in the Ma'a Auslaut we have a -y (and not zero as expected) that can hardly be regarded as a trace of a former *-b. ${ }^{19}$ In any case, Blažek's $(1990,38)$ AA *hami (?) "3" based on the comparison between Eg. and Bed. "3" (including also the Guanche numeral "3", cf. below) is not well-founded even if Bed. $\sqrt{ }$ mhy and SBauchi ${ }^{*} \sqrt{ } \mathrm{mKy}$ were related to $\mathrm{Eg}$. hmt via metathesis. But this - as correctly stated by A. Zaborski (l.c. supra) - is at the moment quite improbable.

Another difficult question is how to evaluate CCh.: Mandara * $\sqrt{h k r d}$ " 3 " [GT] ${ }^{20}$, where, in principle, we may account for the regular shift of $-\mathrm{r}-<\mathrm{PCh} .{ }^{*}-\mathrm{n}$ - and for a prefix *h- (of numerals???), which eventually leads to assuming ${ }^{* *} \mathrm{hV}$-kind-. The cognacy of the Mandara numeral seems thus phonologically fully possible, although it might just as well be combined with Brb. *kraḍ "3" [Zvd. 1974, 107, §7; 1975, 47, §7.0] as suggested in JI 1994 I 168A, which, however, would lead to a completely distinct AA root. Furthermore, the dental radical is apparently additional, cf. CCh. *ma-/ga-h-kər $<{ }^{*}$-kən [GT]. ${ }^{21}$

Another surprising coincidence is represented by the isogloss of SOm. *makan "3" [Blz. 1990, 38] = *mākan $>$ *makkan (hence *-m by assimilation) [GT] ${ }^{22}$ || WCh.: Dira miyahk»n "3" [Krf.] | SBauchi *makwan “3" [Blz. 1990, 38] = *myah(k)an [GT]23 || CCh. *ma-kanu “3” [Blz. 1990, 38] = * $\mathrm{m}^{\mathrm{w}}$ āhkan (?) [GT]. ${ }^{24}$ As far as I know, H. G. Mukarovsky $(1987,36)$ was probably the first to point to the connection of the Ch. m-(h)-k-n/r/d forms, Bed. $\sqrt{m h y}$, and SOm. * $\sqrt{\mathrm{mkn}}$. V. Blažek $(1990,38)$ unified all the extended varieties of PCh. ${ }^{*} \sqrt{\mathrm{kn}}$ " 3 " (prefix *m-, postfix *-d) with SOm. *makan under Common AA *(ma)-kanu-(di) “3”. Similarly, M. Lamberti $(1993,70)$ equated the South Omotic stem with the Chadic m-k-n forms under a South Afro-Asiatic *mVkkVn- "3", which can only be true if we accept a prefix $\mathrm{m}$ - in both branches, which is certainly the case with PCh. ${ }^{*} \mathrm{kn}$ " 3 ", but we do not yet know anything about SOm. *mākan in this respect, whereas Bed. $\sqrt{ }$ mhy can hardly be related as the ultimate root cannot be isolated as $* * \sqrt{\mathrm{mh}}$.

${ }^{19}$ Cf., e.g., the zero reflex in Ma'a we "1" vs. WRift *wak "1", although the case of Ma'a hai "4" vs. ERift *hak“4” speaks against (Zaborski 1987, 343, §1 and §2).

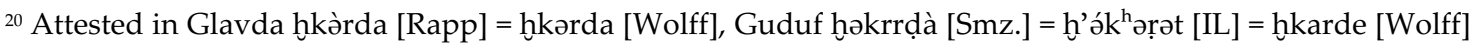
(Mandara group: Wolff 1974, 16).

${ }^{21}$ Cf. Lamang ḩkóná [Wolff] | Dghwede hkré [Frick] = hkare [Wolff] = xókṛè [IL], Ngweshe khwárò [IL], met. < *hkwar- [GT], Ghvoko hkkwaro [Wolff] | Kotoko gahkər [Mch.] = gáhkkór [Lukas] = làkòrà [Bouny] (CCh.: Wolff 1974, 16; Ch.: JI 1994 II 326-7).

${ }^{22}$ Ari maakkan, makkán, mıkkın [Bnd.] = māken [Bliese 1982], Banna məkəm [Bnd. 1971, 264] = m² ${ }^{\curvearrowright}$ [Bnd.], Hamer makan [Crl. 1942, 262] = məkkan [Flm.] = m'aḳan [Lydall], Dime mekem [Bnd. 1971, 263] = mikkım [Flm.], Karo makàmm [CR 1927, 252], Bako makken [Da Trento 1941, 206] (SOm.: Bnd. 1971, 263-264; 1994, 160, \#86; Zbr. 1983, 388).

${ }^{23}$ Attested in Geji mekan [Gowers] = mékán [IL] = meekan, $/ n$ [Smz.] = mekn [Krf.], Guruntum mian [Gowers] = myan [Smz.], Kir ywe:n [Smz.], Buli min [Gowers] = mìỳn [IL] = mye:n [Smz.], Tule mànkí [Smz.], Jimi mwaikan [Gowers], Pelu dè-mèèkan [Smz.], Zul myahkan [Smz.], Barang myakan [Smz.] (SBauchi data: Smz. 1978, 39, \#76).

${ }^{24}$ Cf. Ga'anda mahkən [Krf.], Hwona mahən [Krf.] | Bura and Margi makər [Wolff], Margi-Gwara makəno [Wolff], Chibak makr [IL] = makər [Wolff] | Bata mooaakĕn [Str.] = mwakən [Mch. 1950, 59], Bachama mùwa:kún [Skn.], Nzangi mwọokən [Mch. 1950, 59] = menfén (sic) [Str.], Gudu makın [IL] | Sukur má:k ’̀̀n [IL] | Paduko məkra [Mch. 1950, 59; Wolff] | Matakam màkâr [Schubert], Mofu máákàr mahkàr [Brt.], Gisiga-Dogba maakar [Lks.], Muturwa makir [Str. 1910, 456] (CCh. data: Wolff 1974, 16). 
Three scholars, E. Zyhlarz (1931, 135-136, §3), followed by O. Rössler (1966, 228; 1971, 284, 299) and V. Blažek (1987 MS, 14-15, §3.1; 1990, 38; 1993 MS, 5, §3.1; 1999, 32, §3) supposed a cognacy of Eg. $\sqrt{ }$ hmt with the Guanche word for "3" recorded as (Gran Canaria?) amelotti (cf. amierat-marava "13") [Niccoloso da Recco], (Tenerife?) amiat [Pseudo-Sosa, Marín y Cubas, Berthelot] = amiet [Cedeño de Chil] (Guanche: Wölfel 1954, 4 and 14-18; 1965, 616 and 626630), in which they (except for Rössler) included also Bed. Vmhy. What the ultimate root of the Guanche forms (known to us only through imperfect late medieval records and fully isolated in the whole Berber language family using a totally different root for "three") is, has been answered in different ways. E. Zyhlarz (l.c.) assumed $\sqrt{ }$ ?mrt $\sim \sqrt{ }$ ?mlt (with $-\mathrm{t}$ as part of the root), which he regarded as a correspondence of $\mathrm{Eg} .{ }^{*} \sqrt{\mathrm{hm}} 3 \mathrm{t}(? ? ?)$, but he failed to present any proofs for the hypothetical -3- in the latter root, let alone the enigma as to how the Guanche Anlaut $-\emptyset$ = Eg. $-\mathrm{h}$ and where the reflex of the Guanche $-\mathrm{r} / \mathrm{l}$ - is in the Bedawye root. Later, however, Zyhlarz $(1950,407)$ offered a completely different analysis of the Guanche word: *ameli-hod ${ }^{\mathrm{n}}$ "der andere Zeiger" = "Mittelfinger". J. D. Wölfel (1954, 4; 1965, 616), in turn, singled out the stems *amel(o)-, *amier- in the Gran Canaria records, but how these could be compatible with Tenerife (?) amia/et, he failed to answer definitively: "Deux explications possibles: ou bien le -t appartient au radical, ou bien le -t de amiat est là à la place de -r- de amierat.” Wölfel (1954, 6; 1965, 618) was convinced “que le mot canarien pour " trois » n'a rien à faire ni avec l'égyptien, ni avec le mot bedja. ... ce mot reste inexpliqué et complètement isolé." O. Rössler (l.c.) defined the root of the Guanche numeral as $\sqrt{ } \mathrm{m} \mathrm{mt}$ and derived it from an earlier AA $* \sqrt{\varsigma} \mathrm{mt}$, which theoretically might indeed be a possible source for Eg. $\sqrt{ } \mathrm{hm}$ t may have originated from (due the incompatibility rule of AA * $\mathrm{St}>\mathrm{Eg}$. ht, cf. EDE I 326-7). But he failed to answer why the Gran Canaria records have -r- and -1-. V. Blažek (1999 1.c.) has equally failed to explain both the anomaly of the Anlaut in Eg. vs. Guanche ${ }^{25}$ and the traceless -l-/-r- in Egyptian. So his (Blažek 1990, 38) hypothetic AA *hami (?) "3", which is supposed to underlie the Egyptian, Guanche, and Bedawye parallels, remains ill-founded.

Eg. Vfd (masc. pl. fd.w, fem. fd.t) "vier" (OK, Wb I 582): no Semitic cognates at all, although there were attempts at forcing it together with the numeral "4" in Semitic ${ }^{26}$ and Berber. ${ }^{27}$ Instead, its cognates are to be found in Cushito-Omotic and they are especially wide-

${ }^{25}$ He solely relied upon an outline of Guanche vs. Berber consonantal correspondences (where Berber * $\gamma /$ h- > Guanche h-, h-, g-, but also $\emptyset$ - is admitted) by A. Ju. Militarev (1991, 167-168, more precisely $\S 7$ on p. 168), who, however, did not present any etymological evidence either for the case of Guanche $\emptyset$-.

${ }^{26}$ Several linguists (A. Trombetti 1902, 197, \#4; K. Sethe 1916, 21-22; W. F. Albright 1918, 91 [with reservation]; A. Ember 1926, 302, fn. 10; ESS §4.a.13; recently A. B. Dolgopol’skij 1973, 231-232; 1983, 125; O. Rössler, followed by W. Schenkel 1990, 56; F. Kammerzell 1994, 170, 180 etc.) tried to demonstrate a relationship of Eg. fd (and/or LECu. *afar-) to Sem. *2arba\&- "4". The phonological anomalies were explained various unlikely ways through unjustified steps in the suggested hypothetic chain of phonological changes, e.g. Eg. jfd $<{ }^{*} \mathrm{rfd}<{ }^{*} \mathrm{rbd}<$ *rbS or Eg. jfd < *jfr < *jrfৎ < *2rbS! The Eg.-Sem. equation was rejected already by numerous authors: W. F. Albright (1927, 201), E. Zyhlarz (1931, 136, \#4), W. Vycichl (1934, 70, fn. 1; 1959, 33), W. A. Ward (1985, 239), V. Blažek (1999, 235-241; 1999, 32-38), H. C. Fleming (2000 MS, 6-7). As pointed out already by Zyhlarz (1931 1.c.), the expected correspondence of Sem. *?arba§- would be Eg. *?fh (or *rfh) on the analogy of Eg. sfh = Sem. *šabS- “7”. Besides, Stolbova $(1987,68)$ linked Sem. *?arbaא- to WCh. *rabu “2”, while Blažek $(1997,8 ; 1999,235-241 ; 1999,31-38)$ compared it to LECu.: Orm. (Wellega) bar3ū "palm of hand” [Gragg 1982] and possibly NOm. *biradi- (sic) "finger" [Blz.].

${ }^{27}$ No evident cognates in Berber. The common Brb. root for "four" can by no means be related to Bed.-Eg.Ch. * $\sqrt{f t ̣}$ "four” as proposed by Ju. N. Zavadovskij (1967, 43; 1974, 110; 1975, 50), H. Jungraithmayr (1982, 8; JI 1994 I, 73), cf. e.g. NBrb.: Shilh: Sus qqoz [Dst. 1938, 237] | Nefusa okkoz [Lst. 1931, 285] || EBrb.: Ghadames aqqiz [Lst.] || SBrb.: Ahaggar okkoz [Lst.], Ghat okkoz [Nhl. 1909, 195]. Cp. WCh. *kuç̌A “nine” [Stl. 1987, 208, \#590]. Comparing 
spread in Chadic, cf. Bed. *fadig "four" [GT], ${ }^{28}$ supposed to derive from an older **fardig(a) [Blz. 1999, 33] ${ }^{29}$ ||| NOm. *Peç- [from an older **feț-?] "four" [GT] ${ }^{30} \| \mid$ Ch. ${ }^{*}{ }^{w}$ aḍV [GT]. ${ }^{31}$ The common AA root here can only be $\sqrt{f t ̦ t . ~}$

In Lowland East Cushitic and in two Chadic groups, the presumably same common root appears to be ${ }^{*} \sqrt{\mathrm{fr}}$, cf. LECu. ${ }^{*}$ afr- $\left[\right.$ Black] $={ }^{*}$ afar- $/{ }^{*}$ afur- $[\mathrm{GT}]^{32} \|||$ WCh.: Angas-Sura ${ }^{*} \mathrm{fe}_{1} \mathrm{r}$ [Stl. 1977, 154] $={ }^{*}$ fîr $\left[\right.$ Stl. 1987, 160] $={ }^{*} \mathrm{f}^{\prime} \mathrm{e}_{2} \mathrm{r}[\mathrm{GT}]^{33} \|$ ECh.: PLay (PNancere) ${ }^{*}$ p[o]ri [GT]. ${ }^{34}$

Berber “4” to Eg. fd was rightly rejected already by M. G. Mercier $(1933,309)$ and recently by V. Blažek (ll.c.). V. Brugnatelli (1982, 76), followed by V. Blažek (1997, 9; 1999, 235-241, \#4; 1999, 32-38, \#4) compared SBrb.: Ahaggar ê-feḍ, pl. ê-fụ-en “quantité innombrable (nombre qui dépasse tout ce qu'on peut compter)" [Fcd. 1951-2, 305, cf. Prs. 1974, 407], ETawllemmet ə-fəḍ "se multiplier”, e-fəḍ, pl. e-fəḍ-ăn “1. million, 2. nombre immense” [PAM 1998, 59]. For the semantic shift Blažek quoted Khoe thíyà “four” vs. thíyà "many”. Blažek (ll.c.) suggested alternatively NBrb.: Iznasen, Ait Ammart, Iboqqoyen, Ait Tuzin ța-fụen-t “orteil” [Rns. 1932, 298] | Qabyle ti-fden-t “orteil” [Dlt. 1982, 191] = (dial.) ti-fədn-in “orteils, doigts de pied” [Zvd.] || EBrb.: Ghadames ta-fadən-t "toe” [Lanfry], which is semantically dubious.

${ }^{28}$ Attested as Bed. faḍdeg [Kremer] = fardik [Krockow] = ferdik [Lucas] = fadíg [Rn. 1894, 10; 1895, 76] = fádig [Rn. 1890, 7; Roper 1928, 179] = fadìg [Hds.], Bed. of Beni Amer farig [Rn.] (Bed. records: Dlg. 1966, 60; Blz. 1993 MS, 6-7, \#4.1; 1999, 235ff.; 1999, 32ff.).

${ }^{29}$ There are controversial theories on the etymological analysis of Bed. “4”. A. Trombetti (1902, 197) explained it from PCu. *afar-dig. E. Zyhlarz (1932-1933, 167): Bed. *fadí-g extended by “ein Numeral zusammenfassendes Suffix *-ga”, cf. Bed. -ga "a dual and plural ending” [Roper 1928, 183]. I. M. D’jakonov (1965, 47), did not exclude even an archetype *šaḍig (sic). Acc. to W. Vycichl (1960, 255, 262; 1978, 75), Eg. fd and Bed. "4" are not at all cognates (Vycichl explained Bed. -ḍ- from an ancient *̌̌ or *g!). V. Blažek (1993 MS, 6-7, \#4.1; 1997, 5; 1999, 235241, \#; 1999, 32-38, \#4) supposed PBed. *fa[rd]ig, derived from a compound *fari-da-g(a), where Bed. -g would be identical with Bed. -ga "a dual and plural ending” [Roper 1928, 183] and the prefix *g- of numerals (presumed already by V. Ja. Porhomovskij in PKotoko *gVḍV “four” < *g-fVḍV?). Ch. Ehret (1995, \#93), in turn, derived Bed. -ḍ-

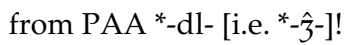

${ }^{30}$ Attested in Janjero hēç-a [h- < ${ }^{*} \mathrm{p}^{\mathrm{h}}$-] “quarter (fraction)” [Flm.] | Mocha pèç-o [ç < *t possible] "quarter” [Lsl.

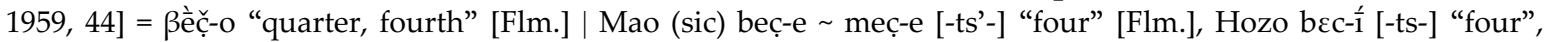

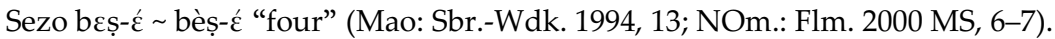

31 The underlying root for " 4 " has been exceptionally well preserved nearly in all Chadic languages. This apparent uniformity cannot be found in the case of other Chadic numerals. For a very detailed presentation and analysis of the reflexes in the Chadic daughter languages see EDE II 600-602. D. Ibriszomow (1988, 68-69) supposed an old quadrinary counting system in Chadic. The PCh. etymon has been set up in various forms: ${ }^{*} \mathrm{p}^{\mathrm{h}} \mathrm{wV} \mathrm{dV}$ [IS 1966, 21] = *f-ḍ- [NM 1966, 235, \#38] = *fwaḍ [Nwm. 1977, 26] = *fwVḍV/*VfwVḍV [Dlg. 1983, 125] = *-p-ḍ [JS 1981, 113; JI 1994 I, 73] = *(m)-p-ḍ-(w/y) [JS 1981, 113A] = *fid-od- (sic) [Stl. 1996, 29]. O. V. Stolbova (1987, 160, §136) has WCh. *firadu based on Bole pórdo [Koelle] = p’ordo (sic) [Stl.], attested elsewhere as poḍdo [Nwm., Lks.] = podo [Grb.] = poḍdau poḍdo [Schuh 1982] = foḍo [IS, NM, Haruna] = fòdḍó [Schuh 1984] = foḍdo o [IL]. The PCh. etymon suggested by P. Newman (1977 1.c.) and A. Dolgopolsky (1983, 1.c.) seems most convincing.

${ }^{2}$ For the LECu. data see Rn. 1886, 845; PB 1963, 469; Black 1974, 104; Heine 1976, 215; Dlg. 1973, 231; Zbr. 1987, 328-340. The etymological connection of LECu. * Zafar- "4" to the Chado-Egyptian isogloss is debatable. E. Cerulli (1938 III, 153) traced back LECu. *afr to “common Cushitic” (i.e., Cu.-Om.) *aft. A. B. Dolgopolsky (1973, 231; 1983, 125; 1988, 629, \#6), in turn, with special regard to LECu. met. var. ${ }^{*}$ ?arf- (above), connected LECu. ${ }^{*}$ ?afarto Sem. *?arbaई- "4", which he explained as a met. of an earlier * $\sqrt{b r}$. Dolgopolsky's theory was queried by F. A. Dombrowski \& B. W. W. Dombrowski (1991, 341). At the same time, Dolgopolsky $(1983,125)$ compared Sem.LECu. "4" also to Bed.-Eg.-Ch. "4", although the LECu.-Sem. comparison excludes an equation of LECu. "4" with the Eg.-Ch. root. For the time being, most probable seems a common origin with LECu. *afar- from PAA *Vfr.

${ }_{33}$ For the Angas-Sura data see Grb. 1958, 300, \#1; Jng. 1965, 166, 168, 180-181; Stl. 1972, 182; Hfm. 1975 MS, 18 , \#35; GT 2004, 105. Contrary to O. V. Stolbova $(1996,29)$, who maintained AS ${ }^{*}-\mathrm{r}<\mathrm{Ch} .{ }^{*} \mathrm{CVdVC}$ (while PCh. *CVd$\rightarrow \mathrm{AS}{ }^{*} \mathrm{CVt}$ ), I see no justification for explaining AS *-r = PLay *-r from common Ch. *-d.

${ }^{34}$ Cf. Nancere peri [Hfm.], Lele poring [Hfm.] = pōrīng [WP 1982, 77], Dormo porin [Hfm.], Gabri porin [AF] = pari [Dcr.], Chire porbu [Hfm.], Kabalay pori [Hfm.] (Lay gr.: Hfm. 1972, 204). 
These data, according to our present knowledge, can by no means be explained from $\mathrm{AA} * \sqrt{\mathrm{ft}} .^{35}$

Eg. Vdj (masc. dj.w, fem. dj.t) "fünf" (OK-, WB V 420) is in fact not a word root at all as it has for a long time been unequivocally regarded as a nisbe of the extinct Eg. word ${ }^{*} \mathrm{~d}$ or ${ }^{*} \mathrm{jd}$ "hand" (Osing: *díy.aw * "die zu einer Hand Gehörigen"), akin to Sem. *yad- "hand". ${ }^{36}$ A similar semantic shift is attested in SCu.: Dahalo dáwàtte "5", act. *daßa-watte, lit. * "one hand", cf. WRift-Dahalo *daba "hand" (SCu.: Ehret 1980, 162, §ii.a.3). But for phonological and etymological reasons, H. G. Mukarovsky $(1987,45)$ and V. Blažek $(1990,30 ; 1991,210)$ are presumably wrong in assuming a direct cognacy between the Dahalo and Ancient Egyptian numerals for " 5 ".

Eg. ${ }^{*} \sqrt{s_{r s}}{ }^{37}>\sqrt{ }$ sjs (occuring as masc. pl. sjs.w, fem. sjs.t) “sechs" (OK-, Wb IV 40) is, according to communis opinio, ${ }^{38}$ in the light of a few other instances of rhotacism of ${ }^{*} \mathrm{~d}>\mathrm{Eg}$. $\mathrm{r}^{39}$ (attested

35 The underlying PAA form has been heavily debated. Ju. N. Zavadovskij $(1974,110 ; 1975,50)$ : PAA *Vfd (incorrect, since AA plain *-d > Bed. $-\mathrm{d} \sim-\mathrm{t}=\mathrm{Ch} .{ }^{*}$-d). I. M. D’jakonov (1986, 61; 1988, 67): PAA *fVdC/*-fVrC (where C denotes an unclear weak consonant in final position). V. Blažek (1987 MS, \#4.2, 1990, 29; 1993 MS, 6-7, \#4.1; 1999, 235-241, \#; 1999, 32-38, \#4) suggested PAA *fira-du/*fari-du/*faru-di. He explained Eg. \& Om. *-d- vs. Bed. \& Ch. *-d- from a cluster ${ }^{*}$-rd-, i.e. PEg. ${ }^{*}$ fida[r]wa.t < *faridwa.t (?) || PBed. *faridaga $>{ }^{*}$ fa[rd]ig, still preserved in some old records as fardik [Krockow] = ferdik [Lucas], quoted after Almkvist (1883-1887) ||| POm. *aburd- or sim. ||| PCh. *faridu/*farudi (cf. Stolbova 1987, 160, \#136: WCh. *firadu). This reasoning might be valid at least in Bed., cf. Bed. fúdẹa furda "Molo, Ankerplatz" < Ar. furḍ-at- “anchorage, sea-port” [Rn. 1895, 82]. In Eg. too (Eg. fd < ${ }^{*}$ f $d={ }^{*} f r d$ would be plausible). The case of Chadic is more problematic, where we would need to collect sufficient and convincing evidence for common Chadic *d- = Angas-Sura and PLay *-r < AA *-rd-. F. Kammerzell (1994, 22-26; 1994, 180), in turn, proposed a development of Eg. fd = *fitțá- < firțá- < firdá- to set up PAA * $\operatorname{PrD}$, var. * $\operatorname{PrG}$ "four” (though *-G is not justified by the reflexes), based on Eg., Bed., LECu., NOm., Ch. "four” and Sem. *?arba§- (!).

${ }^{36}$ Müller 1909, 191, fn. 2; Sethe 1916, 22, §5; 1927, 60-61; NB̈̈ 313; Brunner-Traut in LÄ II 582; Loprieno in LÄ V 1213, n. 26 and in VI 1308. Ultimately, the same idea was accepted by L. Homburger (1928, 336-337), albeit in a chaotic form (misquoting the Eg. word as d.t pace Lexa 1922, 176, a rudimentary mistake!) and along with a number of dubious African parallels.

${ }_{37}$ The older Eg. root * $V_{\text {srs }}$ was still preserved by srs sjs “Art Leinen: Sechsgewebe” (MK, Wb IV 40, 8 and 200, 17).

${ }^{38}$ For the Eg.-AA etymology see Erman 1892, 117 and 127, fn. 1; Ember 1911, 89; 1912, 90, fn. 4; 1914, 303; Sethe 1916, 19-20; Albright 1918, 90, fn. 2 and 91; 1926, 188-189; Farina 1926, 21; Behnk 1927, 82, \#16; ESS §4.i; Zyhlarz 1931, 134, 137; Vycichl 1934, 42, 77; 1953, 42; 1957, 21; 1958, 378; Greenberg 1955, 60; 1963, 62; D'jakonov 1965, 47 (with doubts about Eg. srs); Rössler 1966, 227; Zavadovskij 1974, 108, \#9; 1975, 48; Hodge 1975, 15 and 24 , \#161; Loprieno 1986, 1308 and 1316, n. 25-26; Blažek 1987 MS, 31; 1999, 39-42, §6; Bomhard 1988, 446-447; OS 1988, 79, \#64 (excluding Eg. srs); Dombrowski-Dombrowski 1991, 342; Lipiński 1997, 287, §35.11; Schenkel 1997, 114, Abb. 4, n. 4. Apparently ignoring the fact of an occasional development of Eg. $r<* d$ (below), V. Blažek (1990, 3940) surprisingly denied the cognacy of Egyptian and Semitic " 6 " and, instead, he preferred the phonologically naturally more comfortable equation of Eg. *srs with Sem. *talāt- "3", which he even extended to ECu. *šazḥ-, *šizh-, * sazih - "3" explaining its *-z- with a shift of *-z-<*-ls- <*-lč-, which is attested nowhere.

${ }^{39}$ Cf. (1) Eg. rj.t "Farbe zum Schreiben und Zeichnen, Tinte" (MK, Wb II 399, 9-12) equated by Th. O. Lambdin $(1953,149)$ and O. Rössler $(1966,227)$ with NWSem. * dy: OT Hbr. (hapax) dəyō, Aram. dəyūtā, Syr. dəyōtā, dəyūtā "ink", which is suggested to be an early loan from MEg. But even so, the change $\mathrm{r} \sim \mathrm{d}$ is highly remarkable. Contrary to Rössler, Lambdin explained OT Hbr. dəyō as a graphemic error for *rəyō, which contradicts the rest of the Canaanite evidence. (2) Eg. hrd “child” (PT, Wb III 396-398) equated by O. Rössler (1971, 296, 306) with Sem.: Geez hədāṭ "a small amount, little, a little while, few in number ...” [Lsl.], cf. Geez لhutṭ "to be small” etc. (Sem.: Lsl. 1987, 269). (3) Eg. srq “öffnen” (PT, Wb IV 201-203) compared by O. Rössler (1966, 227) with Ar. Všdq “weit öffnen” [Rsl.] = "avoir les coins de la bouche très-larges (se dit d'un homme dont la bouche est très-large quand il l'ouvre)" [BK I 1205]. Ignoring these facts, V. Blažek (1990, 39-40) denied the cognacy of Eg. and Sem. "6" and in- 
also in the Kefoid reflexes and a number of Chadic daughter languages quoted below), evidently identical with Sem. *šidš- "6" [Sethe] = *šidț- [Djk., Lipiński] ${ }^{40}|| \mid$ Brb. ${ }^{*} \sqrt{s d s}>$ *sadis (south) vs. *sddís (north) "6" [Zhl.] = *sids [Djk.] = *saḍis *sūḍus with *-ḍ- <*-dd- [Blz. pace Prasse] = *sdis [Lipiński]. Among the derivatives of Common Afro-Asiatic " 6 ", the above listed forms, including Egyptian, undoubtedly represent reflexes of a NAA * $\sqrt{s d s}$, whereas the related Southern Afro-Asiatic daughter languages display the original biconsonantal $* \sqrt{s d}$, which apparently had

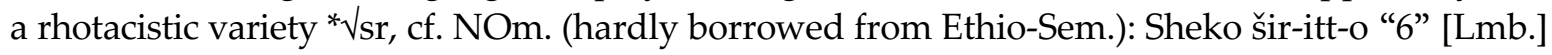
| PKefoid (PGonga) *šir-itt- “6” [GT] ${ }^{41}$ || WCh. *sidu “6” [Stl. 1987, 176, \#288]: Hausa *sidda [Grb., Djk.] > šídà, Sokoto dial. šíddà [Abr. 1962, 809],,42 Gwandara šídà [Mts. 1972, 108] | Ngizim sedu [Koelle] = zòdù [Schuh 1981, 179] = ż̀dù [Krf.], Bade ̀̀zdù [Krf.] || CCh.: Gidar sĕrrĕ [Str. 1910,

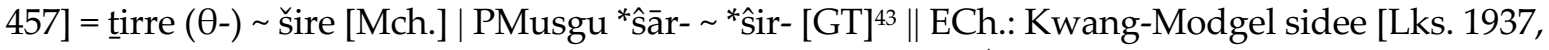
96]. ${ }^{44}$ Especially noteworthy from the standpoint of SAA * $\sqrt{\mathrm{sr}}$, is the suggestion by V. Blažek (1987 MS, 31) about a possible ancient areal parallel like PDravidian *caru "6" [DED §2051].

Eg. Vsfh (masc. sfh.w, fem. sfh.t) "sieben" (OK, Wb IV 115) is identical with Sem. *šibs[Conti l.c.] = *šábS- “7” [Dlg. 1986, 79, \#16], as has long been commonly accepted. ${ }^{45}$ The

stead, he preferred to equate Eg. *srs with Sem. *talāt- “3”, which he even extended to ECu. *šazḥ-, *šizḥ̣-, *saziḥ“3” [Sasse 1976, 138] explaining its *-z- with a shift of *-z- <*-ls- <*-lč- (attested nowhere).

${ }^{40}$ Most reflexes in the Semitic daughter languages reflect the third radical as *-š, only Old South Arabian has -t (cf. SD 175: Sabaic s dt ), which, following Garbini (1972), Loprieno (1986, 1316, n. 25-26) considered as a result of

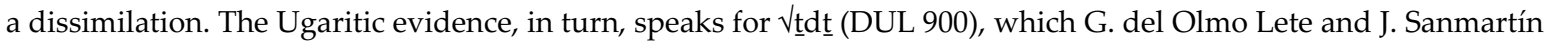
(l.c.) explained from * $\sqrt{s} \mathrm{~d} \underline{\mathrm{t}}$ via assimilation. For the Semitic derivatives with the assimilation of the 2 nd and 3 rd radicals see Brockelmann 1907, 170-171, §60.a; Moscati et al. 1964, 119, §14.8; Grande 1972, 107. Attractive is V. Blažek's $(1990,30 ; 1999,41)$ approach towards the partially reduplicative root structure of the Sem.-Eg.-Brb. isogloss: he supposed in PSem. an older *šid-šid- "3+3” or *šid-tin- "3×2” and so assumed a hypothetical PSem. **̌̌id(with an earlier *-d-) “3”, which he identified with the isogloss of Akk. šizum, later šizû "Drittel-Elle” [AHW 1254] ||| ECu. *šazḥ-, *šizḥ-, *saziḥ- "3” [Sasse 1976, 138]. The problem is, however, that the Afro-Asiatic evidence does not in any way support the reconstruction of Sem. **šidš- à la Blažek, whose $2^{\text {nd }}$ redical must certainly have been *-d-.

${ }^{41}$ Attested in Kafa šír-itt-ō [Crl. 1951, 307] = širr-it-o [Bnd. 1971, 259] = širr-it-o [Lmb.], Mocha šîr-ítt-o [Lsl. 1959, 52] = šir-ítt-o [Bnd. 1971, 260], Shinasha sīr-t-a [Schuver in Grottanelli 1940, 103] = šir-t-a [Grottanelli 1940, 103; 1941, 266] = (Bworo) šir-ítt-ě [Brauner 1950, 70; Bnd. 1971, 259] = širrátà [Lmb.], Anfillo šir-t-o [Grottanelli 1940, 103; Bnd. 1971, 258; so also Lmb.] (Kefoid data: PB 1963, 468; Zbr. 1987, 384; Lmb. 1993, 379). Following E. Cerulli (1951, 309, §xxiv.1), M. Lamberti (1993, 379) and V. Blažek (1987 MS, 31; 1999, 40) too explained the Kefoid forms as loans from Ethio-Semitic $* \sqrt{s}_{\mathrm{s}} \mathrm{s}$, but among its reflexes he referred to (Leslau 1963, 137) there is not one single with -r- $<^{*}$-d-, let alone that the Northern Omotic reflexes do not at all reflect the semi-reduplicative root

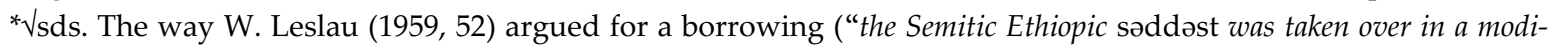
fied form") did not answer any of the phonological questions. It remains thus but to accept the genetically inherited nature of Kefoid " 6 ”.

${ }^{42}$ Earlier, when the rest of the Chadic data was unknown to the compartaive linguists, the Hausa word was explained as an Arabic loan (e.g., Greenberg 1945, 94 with the understandable note "derivation doubtful"), but the wide range of Chadic cognates (impossible to be regarded as coming from Arabic) has made it evident that the Chadic numeral is genetically inherited from the Common Afro-Asiatic lexical stock.

${ }^{43}$ Attested as Musgu saara (sic, s-, probably for sl-) [Roeder] = sáára (s-) [Krause] = taara (sic, t-, probably for tl-) [Overweg] = tará (sic, t-, probably for tl-) [Rohlfs], Mbara ŝ́rá (4-) [TSL 1986, 270], Kad’a ŝ́rè (sl-) [Brt.-Jng. 1993, 133], Munjuk ŝaara [Trn. 1991, 117] = ŝà̀rà [Brt.-Jng. 1993, 133] (Musgu group data: Lukas 1941, 76).

${ }^{44}$ Strangely, H. G. Mukarovsky $(1987,38)$, equated the Chadic numeral (instead of the Sem.-Eg.-Brb. isogloss

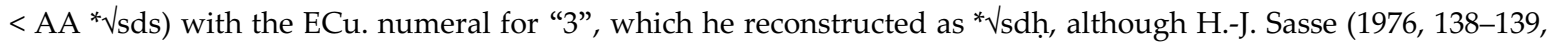
135) assumed ECu. *šaziḥ-/*̌̌Vzḥ- “3”.

45 See Reinisch 1874, XII; Erman 1892, 118; Ember 1911, 91; 1912, 90, fn. 4; 1926, 308, \#2; Sethe 1916, 20, §7; ESS §9.b.2; Albright 1918, 91; 1923, 68, fn. 1; 1926, 189; 1927, 199-201; Lang 1923-1924, 552; Farina 1924, 316; 1926, 14; 
Amarna cuneiform evidence (šapha) and Coptic, cf., e.g., (S) cas=f, corroborate the vocalization *safh.aw (m) vs. *safh.at (f). The Lautverschiebung of Eg. ${ }^{*}-\uparrow>-\mathrm{h}$ was explained by K. Sethe $(1916,20, \S 7)$, F. Behnk (1927, 82), and A. Loprieno (1986, 1316, n. 27) - correctly - on the basis of the analogy of Eg. wsh vs. Sem. *VwšY "wide", although they did not realize the reason for this. ${ }^{46}$ In fact, here we have - instead of an the influence of the Anlaut on the following numeral (Eg. hmn, cf. Blažek 1999, 43) - rather a Lautverschiebung generated by the incompatibilty of $s+S$ in the same Eg. root (EDE I 326). As for the anomalous Eg. -f-, W. Vycichl $(1958,398)$ postulated a combinatory change due to the cluster $-\mathrm{fh}-<^{*}-\mathrm{f} \gamma-<{ }^{*}-\mathrm{p} \gamma-<{ }^{*}-\mathrm{b} \gamma-\left(\right.$ ?). ${ }^{47}$ Whether the Berber numeral for "7" is also related as it was suggested by a number of scholars, ${ }^{48}$ is, presumably, hardly a question itself, but the disturbingly anomalous loss of * Berber and Tuareg reflexes has to be explained, ${ }^{49}$ cf. NBrb.: Tazerwalt ssa (m), ssa-t (f) [Prasse] || EBrb.: Ghadames sā (m), sā-t (f) [Lanfry 1973, 327, \#1410] || SBrb.: Ahaggar e-ssa (m), e-ssāhet (f) [Fcd. 1951-2, 1798] = ə-ssa (m), ə-ssāh-ət (f) etc. [Prasse 1969, 89, \#620], Ghat sah-et (f) [Nhl. 1909, 66, 205]. The underlying PBrb. root is thus debatable..$^{50}$

The attestation of this root for "7" in Southern Afro-Asiatic is sporadic and not without uncertainty, cf. LECu.: Elmolo s'ápa "7" [Heine 1980, 209] = sapa [Lmb.] ${ }^{51}$ ||| NOm. (borrowed from Ethio-Sem.?): Sheko šabātto “7” [Lmb.] | Kefoid “šab-att- “7” [GT]52 || SOm.: Hamer soßb-a [Flm.], Karo sopb-o [Flm.] (SOm.: Bnd. 1994, 157) ${ }^{53}$ || CCh.: PMafa-Mada *čib- “7” [GT]:54 Mofu čibe (tsch-) [Str. 1922-3, 122], Gwendele cíba [Colombel], Hurzo cíba [Colombel] = číbà [Rsg. 1978,322 , \#622].

Behnk 1927, 82; Zyhlarz 1931, 137, §7; Lexa 1938, 223; Rössler 1952, 142, \#66; 1966, 228; Vycichl 1958, 378; IlličSvityč 1964, 7, \#22; D’jakonov 1965, 47; Zavadovskij 1974, 109, \#10; 1975, 49; Hodge 1976, 15, \#162; Conti 1978, 28, fn. 2; Loprieno 1986, 1308; 1994, 120; 1995, 32; Blažek 1990, 31; Lipiński 1997, 287, §35.12.

${ }^{46}$ W. F. Albright $(1918,91)$ assumed the chain of phonetic shifts: Eg. sfh < ${ }^{*}$ sfh $<{ }^{*} \mathrm{sfS}<{ }^{*} \mathrm{sbS}$. A. Ember (1926, 308, fn. 4-6) was, in turn, inclined to explain the change by "partial assimilation" of $\mathrm{S}$ to $\mathrm{f}$ and that of $\mathrm{b}$ to $\mathrm{s}$, for which he, however, failed to provide any parallel evidence. A. Loprieno $(1994,120)$ arbitrarily extracted the Egypto-Semitic parallel from a common ${ }^{*} \operatorname{s} \dot{p} \gamma$, but he failed to demonstrate the evidence for its ${ }^{*}-\dot{\mathrm{p}}-$ and ${ }^{*}-\gamma-$, which is attested nowhere.

${ }^{47}$ Where V. Blažek (l.c.) attributed the presence of -s- also some importance with a hint on Eg. hsb (PT 448c $\left.{ }^{W}\right)$, an occasional variety of standard hsf “abwehren” (OK-, A ̈̈G 51, §114).

48 Zyhlarz 1931, 137, §7; Rössler 1952, 142, \#66; 1966, 228; D’jakonov 1965, 47; Vycichl 1966, 269; 1974, 63; 1992, 385; Zavadovskij 1967, 43; 1974, 109, \#10; 1975, 49; Blazek 1990, 31; Lipiński 1997, 287, §35.12

49 There is a small number of Ghadames and Augila words, where PBrb. * $\underline{b}$ is not reflected as expected (namely, as b)), cf. Kossmann 1999, 79-80, §3.11; also Blažek 1999, 43 (discussing the case of the word for "heart”).

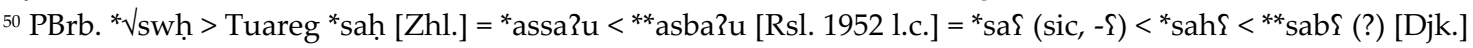
$=* \sqrt{s} 32$ [Rsl. 1966 l.c.] $={ }^{*} \sqrt{ } h_{1} s_{2}$ [Prasse 1.c.] $=*$ sa [Zvd., Lpn.] = *āh [Blz. 1990 1.c.]. In the view of Ju. N. Zavadovskij $(1967,43)$, the “берберская форма представляется апокопированной”. M. Kossmann $(1999,76, \S 3.7$, \#106), in addition, who did not even list Brb. "7" among the instances of * $\underline{b}$, conceived the $-\mathrm{h}$ - appearing in Tuareg fem. forms (Ahaggar e-ssāh-et, Ghat sah-et) as intrusive in certain fem. numerals whose stem ends in long vowel.

${ }^{51}$ B. Heine $(1973,282)$, however, recorded Elmolo típa? "sieben”, which continues ECu. *tVzb-.

${ }^{52}$ Attested as Kafa šabáttō (cf. šábo “70”) [Crl. 1951, 307] = šabatto [Lmb.], Mocha šabátto (cf. šáb/bo “70”) [Lsl. 1959, 49], Shinasha sawáte [Schuver] = šawata [Grottanelli 1940, 103; 1941, 266] = šâwatta [PB] = šawāta [Lmb.], Bworo šawátě [Brauner 1950, 70; Bnd. 1971, 259], Anfillo šabattó [Grottanelli 1940, 103; Bnd. 1971, 258] (Kefoid data: PB 1963, 468, 478; Zbr. 1983, 384; Lmb. 1993, 385). Generally in Ethio-Semitic and Omotic studies (e.g., Cerulli 1951, 309, §xxiv.1; Leslau 1959, 49; Lamberti 1993, 385), the Kefoid numeral is supposed to have been borrowed from Ethio-Semitic, cf. Amh. säbatt. But what explains the anomalous Anlaut in a loan?

${ }^{53}$ L. Bender (l.c.) suspected (with a question-mark) in these Southern Omotic forms borrowing from Arabic.

${ }^{54}$ Some of the Mafa-Mada group forms were first compared with Sem. *šabৎ- by V. Blažek $(1990,31,38)$, who, however, included in this equation also his ECh. *cabu " 3 ” (although the evidence suggests rather *sūb-, cf. JI 1994 II 327), for which cf. rather LECu.: Elmolo sếpe “3” [Heine 1980, 209]. 
It remains for later research to clarify whether the isogloss of ECu. *tVzb- "7" [Sasse 1976, 139] ${ }^{55}$ || POm. *tabz- "7" [GT] ${ }^{56}$ is eventually also related with a prefix t- (?) and a secondary voicing of ${ }^{* *}$-s- in the cluster with *-b-, i.e., ${ }^{* *} \operatorname{tasb}(\Omega)->^{*}$ tazb- (hence POm. *tabz- via metathesis $<*$ tazb-?). The lack of any trace ${ }^{*}-\varsigma$ is, in any case, a not too supportive a circumstance.

Eg. Vhmn (masc. hmn.w, fem. hmn.t) "acht” (OK-, WB III 282) is to be vocalized on the basis of its Amarna cuneiform reflex haman (Albright 1926, 188-189) and the Coptic evidence, e.g., (S) smoun as *hămấn.[ă]w, which almost perfectly coincides with Sem. *tamāniy- "8". ${ }^{7}$ This comparison has been commonly accepted ${ }^{58}$ in spite of the disturbingly anomalous Anlaut. After several vain attempts at resolving this mystery, ${ }^{59}$ the most natural reason is easy to be found, namely the influence of the Auslaut of the preceding numeral $\left(V_{s f h}\right)$, a quite natural factor leading to phonologically irregular numerals, ${ }^{60}$ i.e., analogy, which V. Blažek $(1999,45, \S 8)$ in this case avoided even to mention as an alternative. Whether Brb. *tam "8" [Djk.] = *tām/*hittām "8" [Prasse] belongs to the firmly established triconsonantal Sem.-Eg. *tmn, is heavily debated as both the lack of the $C_{3}$ and the Anlaut are anomalous. ${ }^{61}$ Turning against the conventionally accepted equation of the Egyptian, Semitic, and Berber roots mentioned above, step by step, V. Blažek (1991, 210; 1993 MS, 6, §3.5; 1999, 45, §8) excluded every single of the

55 The East Cushitic word was borrowed into PBaz *tizzaba $\rightarrow$ PSNilotic *tıs $\Lambda$ p $\rightarrow$ NMa'a sapa (Heine \& Rottland \& Voßen 1979, 85).

${ }^{56}$ Attested in NOm.: Basketo tabz-ā [Crl. 1938 III, 108], Doko tabs-ā [CR 1927, 248], Dollo tābez-ā [CR 1927, 250] | Dizoid *tubs- [GT]: Dizi tŭs-ú [Allan 1976, 381] = tus-u [Toselli 1938, 13] < *tuss- < *tubs- [GT], Sheko tubs-u [CR 1925; Bnd. 1971, 262] || SOm.: Hamer tobb-a [Crl. 1942, 262], Karo tsōb-à (sic, ts-) [CR 1927, 252], Ari tabz-a [Bnd. 1971, 263] = tabž-á [Bnd.], Galila (Ari) tabž-á [Flm.], Bako tabz-e [Da Trento 1941, 206], Dime toss-um [Bnd.] = tuss-o [Flm.] < *tuss- < *tubs- [GT] (SOm. data: Bnd. 1994, 157).

${ }^{57}$ In a surprising manner, A. Loprieno (1986, 1308, n. 28), also here, misinterpreted Ar. t- as a reflex of Sem.

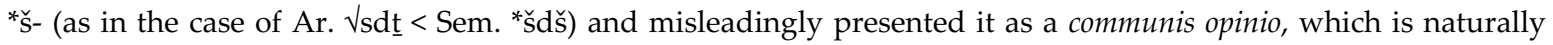
not at all the case (cf., e.g., Moscati et al. 1964, 43, §8.59).

${ }^{58}$ Hommel 1883, 96, \#11; Erman 1892, 116; Ember 1911, 91; ESS §10.a.32, §11.a.46; Albright 1918, 92; 1926, 188189; 1927, 200-201; Farina 1924, 324; 1926, 20; Behnk 1928, 82, \#28; Zyhlarz 1931, 137-138; Bravmann 1933, 147; Lexa 1938, 224; Rössler 1952, 146, \#73; 1966, 228; Vycichl 1959, 33; 1966, 269; 1974, 63; 1992, 385; D’jakonov 1965, 47; Zavadovskij 1967, 43; 1974, 109, \#11; 1975, 47; Hodge 1976, 15, \#163; Loprieno 1986, 1308, cf. fn. 28; Belova 1989, 14; Blazek 1990, 31; Schenkel 1991, 116; Dombrowski-Dombrowski 1991, 347.

${ }^{59}$ So, for instance, K. Sethe $(1916,20, \S 8)$ correctly stated that Eg. h vs. Sem. *t are "sonst nicht belegt", but because of $\mathrm{m}+\mathrm{n}$, such a shift may undoubtedly have taken place, and, in addition "vergegnwärtigt man sich" assuming that Eg. h > Cpt. S worked "ebenso wie" Sem. *t $>$ Hbr. š, which, however, is an error and does not prove a anything about Eg. h- vs. Sem. *t-. Sethe concluded that "So wird man auf die Vermutung geführt, daß in diesem š nahestehender Laut das Ursprüngliche gewesen sei, und daß das äg. h nur eine unvollkommene Wiedergabe desselben darstelle". W. F. Albright (1918, 92 and fn. 2), in turn, assumed a chain of shifts (Eg. hmn < *̌mn < tmn), where, in his view, "ᄃ̌ for $\theta$ arises by dissimilation from the dental n", although, pro primo, OK h- has not been known as a phoneme issuing from older *̌s, and, pro secundo, the expected Egyptian reflex of Sem. * course, a shift of Eg. h- $<^{*}$ s- is otherwise unkown. Later Albright (1927, 200-201) worked with the Lautverschiebung of Eg. hmn $<{ }^{*} \mathrm{fmn}<{ }^{*}$ tmn, which he equally failed to justify.

${ }^{60}$ Cf., e.g., Old Church Slavonic devętь "9" < IE *newn under the influence of *desętь "10".

${ }^{61}$ The Sem.-Eg.-Brb. comparison was supported by O. Rössler (1952, 146, \#73; 1966, 228); W. Vycichl (1959, 33; 1966, 269; 1974, 63; 1992, 385); I. M. D’jakonov (1965, 47); Ju. N. Zavadovskij (1967, 43; 1974, 109, \#11; 1975, 47). Rössler (1952, 146, \#73) assumed PLibyan *tamnu(m), *tanatu (f), hence *tamno (m), *tamnt and regarded *t- as regular (!) for Sem. *t-. Later, in turn, Rössler $(1966,228)$ considered the Anlaut of the Berber numeral "mit $\mathrm{t}$ für lautgesetzliches s" as being due to assimiliation to "9" (Brb. *Vtzh). The change of $\mathrm{m}<{ }^{*} \mathrm{mn}$ was explained by D'jakonov $(1965,47)$ via assimilation < *tamn. Similarly, for Zavadovskij $(1967,43)$ too, the Berber “ Форма кажетсл апокопированной" from the triconsonantal PAA root. 
three comparanda. For him, Brb. *t- vs. Sem. *t- was an otherwise unattested match, which is, however, not entirely true. ${ }^{62}$ Therefore, he proposed a completely new etymology for Berber "8", namely SCu.: PRift *tam- "3" [Ehret], ${ }^{63}$ where he assumed a pattern of $(5+) 3=8$ to have worked just as in the case of ECu. *ša/izh- "3" vs. *ša/izzet- "8". This sugestion seems indeed attractive. But Blažek also found (pace Holmer 1966, 35) it evident that Eg. hmn is "deriving quite naturally from" Eg. hmt " 3 " (!) in the same way, although he did not explain this derivation, e.g., how did the -t of " 3 " disappear in " 8 ", or, what was the function of -n of the latter numeral. Thirdly, in Sem. *tamāniy- "8", instead of a genetically inherited root * $\sqrt{\mathrm{t} m n}$, he saw an inner Semitic innovation from the contraction of a hypothetic compound **āniy-mā/**tanīy-mā "the second one no", or alternatively from **tāniy-/tanīy-min-( (assar-) "the second from (ten)". All this fails, however, due to the fact that the same PAA biconsonantal root * $\sqrt{c}$ m for "8" appears also in NOm.: PKefoid (Gonga) *šim-itt- "8" [GT]. ${ }^{64}$ A borrowing from Ethio-Semitic ${ }^{65}$ is hardly the case with the Kefoid numeral (isolated within Omotic) for several reasons. ${ }^{66}$ It is here to be remarked that the Egyptian, Semitic, and Berber numerals "8" were compared by W. Vycichl $(1959,33)$ also with Bed. asemháy asumhay "acht” [Rn. 1895, 31] = asimhéi [Roper 1928, $155]$ in spite of its analysis as a compound commonly accepted since L. Reinisch $(1894,7) \cdot{ }^{67}$

Eg. Jpsd "nine (9)" (OK, Wb I 558) is a word with a very difficult etymology, ${ }^{68}$ traditionally identified with Semitic *tiš(a)\&- "9" [GT] (Semitic data: Moscati et al. 1964,

${ }^{62}$ Cf. SBrb.: EWlmd. a-tăkămma, pl. i-tăkămma-t-ăn "bras supérieur” [PAM 2003, 785] ||| Sem. *tVkm- "neck and shoulders” [SED]: Ug. tkm “1. Nacken mit Schulter, 2. oberer Teil eines Gebäudes” [WUS] = "shoulder” [DUL 903], Hbr. šəkem “der Nacken mit den Schulterblättern, bes. als Körperteil, auf dem man eine Last trägt, der Teil des Körpers (Rücken), auf den man jem. schlägt, 2. Landstrich, eigtl. Rücken des Landes” [GB] = "1. the (nape of the) back or neck of a person, 2. shoulder (as a part of the body on which to carry a heavy load), the shoulder joint (as a part of the carcass of a sacrificial animal)" [KB] (Sem.: GB 826-7; WUS 334, \#2866; Faber 1984, 210, \#50; Lsl. 1987, 496; Voigt 1994, 107; KB 1492-3; SED I 251, §281) ||| PCu. *sVnkw “1. затылок, спина, плечо, 2. то место, на

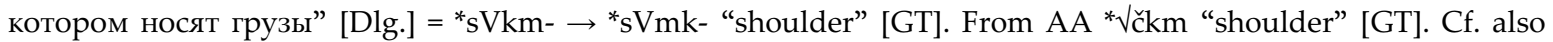
Dlg. 1983, 136, \#9.2 (Sem.-Bed.-LECu.). Hardly a borrowing from Arabic, where its reflex (if related at all ...) has undergone serious semantical shift, cf. Ar. takam- "1. (tracé du) chemin, (milieu de la) route" [BK I 231b] = takam-, tukm-at- "1. milieu (du chemin), 2. chemin, voie" [Blachère 1210a] = takm- (sic) "shoulder (of road)" (sic) [Faber]. Besides, A. Ju. Militarev (1991, 242) admitted AA *č > Brb. *s, (?) *̌s, and also *t (no question-mark), although he did not provide the lexical evidence.

${ }^{63}$ Which was combined by Ch. Ehret $(1980,290)$ with Dahalo Ríttātốni "3rd day after tomorrow" to reconstruct SCu. *2itām- "tris, set of three".

${ }^{64}$ Attested in Kafa šim-itt-ō [Crl. 1951, 307; Bnd. 1971, 259] = simm-ít-o [PB] = šimm-itt-o [Lmb.: so also in Sheko!], Mocha šim-ítt-o [Lsl. 1959, 51; Bnd. 1971, 260], Shinasha sim-īt-a [Schuver in Grottanelli 1940, 103] = šimat-a [Grottanelli 1941, 266] = šim-ítt-a [PB] = šəmm-ətt-à [Lmb.], Bworo šim-ítt-ě [Brauner 1950, 70; Bnd. 1971, 259], Anfillo šim-itt-ó [Grottanelli 1940, 103; Bnd. 1971, 258] (Kefoid data: PB 1963, 468; Zbr. 1983, 384; Lmb. 1993, 376).

${ }^{65}$ As suggested by E. Cerulli (1951, 309, §xxiv.1) and M. Lamberti (1993, 376).

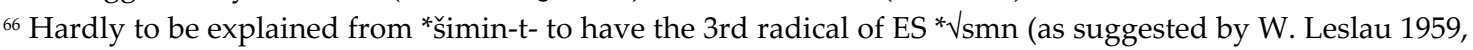
51 with a hint on some Gurage dialects, where -n- was not preserved, cf. Chaha sumut, Muher, Selti səmmut, the vocalization of which do not fit, however), since, suspiciously, Kefoid 6, 7, 8 all have this suffix -Vtt-. In addition, how could ES *s- have become Kefoid *š- if it was a borrowing?

${ }^{67}$ The Bedawye numeral is evidently not an Arabic loan. According to the usually accepted segmentation, the Beja numerals from " 6 " to "9" are formed on the basis of the pattern of Bed. asa "growing" + “1", “2”, “3”, “4” (cf. Bed. Vmhy “3”).

${ }^{68}$ Any inner Egyptian derivation is vain here. Declining its commonly accepted Semitic etymology, V. Blažek $(1999,251)$ tried to explain Eg. psd "9" on the basis of Eg. psd "sich entfernen von, sich abwenden von (r)" (PT, ÄWb I 479; Wb I 556), i.e., “9” < psd $\{$-md.w\} “[one] removed away from \{ten\}”. However, Blažek ignored that the latter is a denominative verb of Eg. ps “back”, and so it may literally have denoted * “den Rücken wenden” (Wb). 
116), ${ }^{69}$ which may seem impossible at the first glance as, in fact, only the second radicals correspond. The initial p- in Eg. instead of an expected *t- is unusual, which, after a few vain attempts, ${ }^{70}$ W. F. Albright, ${ }^{71}$ followed by others, ${ }^{72}$ correctly explained by the incompatibility of OEg. ${ }^{*}$ ts. ${ }^{73}$ But they never discussed the question as to why this sequence turned into Eg. ps-. It is due to another incompatibility law, namely that of OEg. *s\}, which had to turn either to *sh (cf. EDE I 326) or *s (the irregular correspondence of Eg. - $\underline{\mathrm{d}}$ vs. Sem. ${ }^{*}-\uparrow$ occurs in a number of convincing examples, among which there are also roots devoid of s). ${ }^{74}$ In either cases, we get a third radical which is compatible with p- only, the other possible voiceless stop to replace tbeing k-, which is incompatible with both -h $\mathrm{h}$ and - $\underline{\mathrm{d}}$. The choice between -sh vs. -s $\underline{\mathrm{d}}$ was probably decided under the influence of Eg. md "10".

Whether and how Berber "9" (usually bearing the consonants $\sqrt{t}_{\mathrm{t}}$ or $\sqrt{\mathrm{tz}}_{\mathrm{z}}$ ), reconstructed in various forms, ${ }^{75}$ and frequently included in the Egypto-Semitic etymology above, ${ }^{76}$ can be related, is disputed. It is evident, that the medial radicals (Brb. ${ }^{*}$-z- vs. Sem. ${ }^{*}{ }^{-s}$-) are not at all in agreement. In addition, V. Blažek $(1999,47)$ excluded the relationship of the Egypto-Semitic isogloss to Berber "9", which he explained as a contraction of *t(V)-[k]ūzah "[5] + 4", cf. Brb. *hakkūz "4” [Prasse].

The Southern Afro-Asiatic evidence of the root for "9" reflected in Semitic and Egyptian is scarce. It occurs in fact only in ECh. *Vtgs $~ * \sqrt{\text { gst }}$ "9" [GT]77 as suggested by A. Trombetti

69 This Semito-Egyptian equation was accepted by A. Erman (1892, 111); W. M. Müller (1907, 303); A. Ember (1911, 91; 1912, 90, fn. 4; ESS §8.c, 112, §18.a.9, §24.d.4); F. Hommel (1915, 16, \#2); K. Sethe (1916, 20); W. F. Albright $(1918,92 ; 1923,68 ; 1926,189 ;$ 1927, 201); E. Zyhlarz (1931, 138, §7); Sh. Yeivin (1932, 137); H. Mercier (1933, 313314); O. Rössler (1966, 228; 1971, 302, 307); Ju. N. Zavadovskij (1967, 43; 1974, 109, 112; 1975, 49); KHW 153; W. Schenkel (1990, 52, 57; 1991, 116; 1997, 114); J. Zeidler (1992, 205); G. Takács (1999, 141; 2000, 343-344, \#8.3; EDE II 516-7). The same comparison was declined by C. T. Hodge (1976, 15, \#164), V. Blažek (1997, 16; 1999, 250-251, \#9; 1999, 46-47, \#9), and E. Lipinski (1997, 288, §35.14).

${ }^{70}$ E.g., K. Sethe $(1916,20)$ compared this phenomenon to the regular change of PIE * ${ }^{w} \mathrm{a} / \mathrm{o}-\rightarrow$ Gk. $\pi \alpha / \mathrm{o}-\mathrm{vs}$. PIE ${ }^{*}{ }^{\mathrm{w}} \mathrm{e}-\rightarrow$ Gk. $\tau \varepsilon-$, which has, however, not been established in the Egyptian Lautgeschichte as a regular shift.

${ }^{71}$ Cf. Albright 1918, 92; 1923, 68; 1926, 189; 1927, 201.

72 O. Rössler (1966, 228; 1971, 302, 307), W. Schenkel (1990, 52, 57).

73 This reasoning seems acceptable, since the sequence of word initial *ts- is not attested in Old and Middle Egyptian (cf. Wb I 328). Similarly, J. H. Greenberg $(1950,176)$ observed no instance of a dental followed by a sibilant in the Semitic root stock either except for Sem. * $\mathrm{tš \varsigma}$ "9". For the frequent incompatibility problems in the Semitic numerals 1-10, cf. Greenberg 1950, 178, §5.

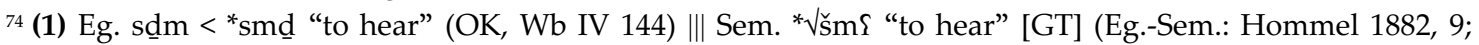
1894, 351, fn. 1; 1915, 16, fn. 3; Müller 1907, 303; Ember 1911, 91; 1912, 90, fn. 4; 1918, 30; 1926, 6; 1926, 309, fn. 8; Yeivin 1932, 137; Vycichl 1934, 63; Vergote 1945, 142, §16.b.23; Cohen 1947, \#82; Schenkel 1993, 143 etc.). (2) Eg. nds "klein, gering" (PT-, Wb II 384-385) ||| Sem. *VnSs “to be small, weak" [GT] (cf. Hommel 1883, 441, fn. 30; 1894, 351, fn. 1; 1915, 16, fn. 3; Erman 1892, 113; Ember 1912, 90, fn. 4; 1926, 6; 1926, 309, fn. 8; 1930, §11.a.43, §24.d.2; Vycichl 1934, 63; Vergote 1945, 147, §24.b.2; Cohen 1947, \#80; Rössler 1966, 228). (3) Eg. ndm “süß, angenehm” (OK, Wb II 378-380) || Sem. *VnSm “to be pleasant” [GT] (cf. Hommel 1883, 98; 1894, 351, fn. 1; 1915, 16, fn. 3; Erman 1892, 113; Müller 1907, 303; Ember 1911, 91; 1926, 6; ESS §10.a.25, §11.a.41; §24.d.1; Vycichl 1934, 63; Vergote 1945, 147, §24.b.1; Cohen 1947, \#81; Schenkel 1993, 143; Loprieno 1994, 120). (4) Eg. dns “to be heavy” (MK, Wb V 468-469) ||| LECu. *Sils-/*Suls- "heavy" [Sasse 1975, 245; 1976, 127] proposed by O. Rössler $(1966,228)$.

75 PBrb. *təzah (?) “9” [GT] = *Vts? [Rössler 1966, 228] = *tașșa3u [Rössler 1952, 143] = *tẓa [Zavadovskij 1974, 109; 1975, 49] = *tiz̄āh *tūzạah [Prasse 1974, 403, 404].

${ }^{76}$ See Zyhlarz 1931, 138, §7; Mercier 1933, 313-314; Vycichl 1938, 135; 1966, 269; 1974, 63; 1992, 385; Rössler 1952, 143, \#74; 1966, 228; 1971, 302, 307; Zavadovskij 1967, 43; 1974, 109, 112; 1975, 49; Zeidler 1992, 205; Takács 1999,$141 ; 2000,343-344, \# 8.3$.

${ }_{77}$ Cf. Lay group *Vtgs [GT]: Dormo tigesu [Hfm.], Gabri tigesu [AF] = tegès [Dcr.], Chire tíngěšū [Hfm.], Kabalay tegesu [Hfm.], Lay tegese [Hfm.] | PSomray * $\sqrt{t s}_{\text {or }}$ * $\sqrt{\mathrm{ds}}[\mathrm{GT}]$ : Somray dōso [Barth], Ndam disa [Bruel] = tiše 
$(1977,53)$ and G. Takács $(1999,141 ; 2000,343-344, \# 8.3)$. The phonological correspondence of ECh. *-g- $<A A *-\{$ is not yet proven, however. As for the metathesis in East Chadic, it is noteworthy that V. Blažek (1990, 32; 1991, 210) supposes Sem. *tišৎ- "9" to reverse the order of Sem. *Sašt- “1”.

Leaving aside the equation with Semitic “9”, G. Takács (EDE II 517-518) discussed all other alternatives (q.v.), and among others he ventured an alternatively a comparison of Eg. psd $<$ * psई with NOm. * $\sqrt{\text { bz }}$ (stem vowel *-i-) "1" and "9" [GT],78 which apparently stands isolated in Afro-Asiatic.

Eg. $\sqrt{ } \mathbf{m} \underline{\mathbf{d}}$ (masc. md.w, fem. md.t) "zehn" (OK, Wb II 184): in spite of the abundance of various etymologies suggested until very recently a completely satisfactory solution has not been found. In any case, the Amarna cuneiform (14 ${ }^{\text {th }}$ cent. BC) evidence (mu-țu $)^{79}$ and Cpt.

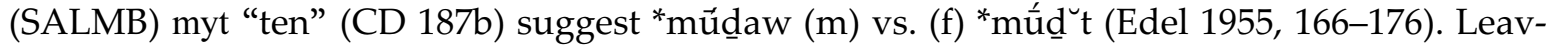
ing aside the evidently untenable etymologies, ${ }^{80}$ we may only describe all the considerable solutions:

(1) F. Behnk $(1928,139$, \#33) saw in Eg. md [possibly < *mg] a metathesis of WCh.: Hausa

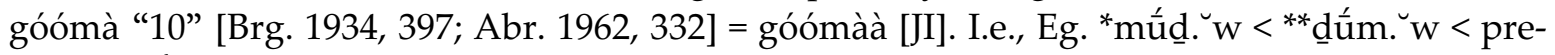
OEg. ** gúm. $\mathrm{w}$ ? It is highly noteworthy that the sequence dm- was not typical in Egyptian. Regarded as "possible" also by V. Blažek (1989, 215-216; 1997, 17; 1999, 251-3, §10; 1999, 47$49, \S 10)$ and Ju. N. Zavadovskij $(1974,104 ; 1975,50-51)$. The Hausa numeral for "10" is a reflex

[Décorse], Tumak disa [Décorse] = bisa [Bruel], Miltu disa [Hfm.], Sarwa doso [Hfm.] | Mokilko géssát [Lukas 1977, 210] = géssá(t) [Jng. 1990, 101] (ECh. data: Hoffmann 1971, 9).

${ }^{78}$ Attested in SEOmeto *bizz-o "1" [GT]: Haruro (Kachama) bĭzz-o [Crl. 1936, 631, 642] = biz-e [Sbr.], Zayse bizz-ō [Crl. 1938 III, 201] = bizz-o [Sbr.], Zergulla biz-o [Sbr.], Koyra (Badditu) bizz-ō [Crl. 1929, 60] = bīz-o [Bnd.] = bížž-o [Hyw. 1982, 215] = bı33-د [Sbr.], Gidicho bīz-e [Bnd.] (SEOmeto: Bnd. 1971, 256-257; Zbr. 1983, 387; Sbr.

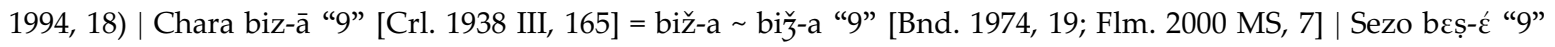
[Sbr.-Wdk. 1994, 15].

${ }^{79}$ Occurs in a list of Egyptian words (EA 368), cf. Smith \& Gadd 1925, 230-8, esp. 236, §15; Lambdin 1958, 186; Edel 1975, 11f.; 1980, 17 \& fn. g.

80 (1) A. Trombetti $(1902,198)$, C. Brockelmann (1908, 487), W. Worrell $(1926,272)$, and G. A. Barton $(1934,30)$ erroneously equated LEg. md, Dem. mt, and Cpt. (S etc.) myt with Sem. *mi3-át- "hundred" [Dlg.], which has rightly been declined by W. F. Albright (1918, 92, fn. 6), later also by F. A. Dombrowski and B. W. W. Dombrowski (1991, 342) and by V. Blažek (1999, 251-3, §10; 1999, 47-49, §10). (2) There is a long tradition of comparing Eg. md with the reflexes of PBrb. *mẹraw "10" [Zhl. 1934-35, 185] = *marāw [Prs. 1974, 403, 405] = *mra (m), *mra-ut (f) [Zvd. 1975, 50-51, §14.0] = *märäw (sic) [Vernus] = *maraw [Mlt., GT], cf., e.g., Gabelentz (1894, 99); Meinhof (1912, 240); Zyhlarz (1931, 137-138, \#8; 1932-1933, 104; 1934, 104, 106, 111, fn. 1); Mercier (1933, 314); Wölfel (1954, 58); Lefebvre $(1955,276)$ and Korostovcev $(1963,14)$ : both misquoting the Brb. root as mzu (sic!); Rössler (1966, 227; 1971, 317); Zavadovskij (1967, 43; 1974, 111-112; 1975, 50-51, §14.0); Loprieno (1986, 1309); Blažek (1989, 215-216; 1990, 41; 1997, 17-18); Dombrowski and Dombrowski (1991, 344); Vernus (2000, 180, 192): Eg. mdw (sic) “a un cognat possible avec le berbère"! Rejected by W. Vycichl (DELC 124) and G. Takács (1995 MS, 4, \#7; 1996, 139, \#35; 1996, $442, \# 2.3$ ) as there is no evidence for Eg. - $\underline{\mathrm{d}} \sim \mathrm{Brb} .{ }^{*}$-r-, while Brb. ${ }^{*}$-w is part of the root (contrary to Eg. masc. md.w vs. fem. md.t). (3) K. Sethe $(1916,17)$ and A. Loprieno (1986, 1309): Eg. md "10" < mo "deep", but they failed to demonstrate the odd semantic shift with typological parallels. V. Blažek (1997, 17; 1999, 251-3, §10; 1999, 47-49, §10) excluded a direct connection. (4) Ju. N. Zavadovskij (1974, 112; 1975, 44) and A. Loprieno (1986, 1316, n. 32):

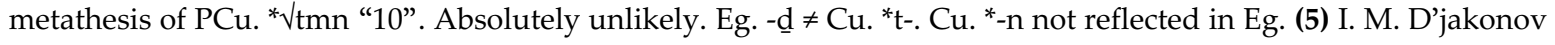
(1986, 61; 1988, 67): Sem. *ma3d- "many”, but Eg. $d$ f Sem. *d. Declined already by V. Blažek (1989, 215-216; 1997, 17) and G. Takács (1994, 217; 1996, 139-140, \#35; 1996, 442, \#4; 1999, 136; 1999, 203). (6) A. Loprieno (1986, 1309, 1316, n. 33) suspected the ultimate common origin of Eg. md "10" and md "deep" with Sem. * Vmṣs "aufsaugen"(!), * $\sqrt{\mathrm{mdd}}($ !) "lang ziehen, ausdehnen", * $\sqrt{\mathrm{m} t \mathrm{t}}($ !) "lang ziehen, ausdehnen”. Impossible. E.g., how should one figure a relationship between "aufsaugen” vs. "10”? Rejected already by V. Blažek (1999, 251-3, §10; 1999, 47-49, §10). 
of PCh. * ${ }^{w}$ am- "10" [Nwm. 1977, 32] = * $\mathrm{g}^{\mathrm{w}} \mathrm{m}$ [JS 1981, 263; JI 1994 I, 165]. ${ }^{81}$ C. Hoffmann (1970, 12-14) and H. Jungraithmayr \& D. Ibriszimow (1994 I, 165) considered PCh. * $\sqrt{ }{ }^{w} \mathrm{~m}$ "10" to be an old Niger-Congo loan (cf. Benue-Congo *-kumi "10"), which would exclude its equation with Eg. md. However, a genuine AA etymology of PCh. ${ }^{*} \sqrt{g^{w} \mathrm{~m}}$ is also possible, cf. AA * Vgm "complete (or sim.)" [GT]. V. Blažek (1987 MS, 41), in turn, combined the PCh.-Eg. parallel with SBrb.: Ahaggar a-gyim (-g்- apud Fcd.) "millier” [Fcd. 1951-2, 444], Ghat a-ร̌im (a-djim apud Nehlil) [-̌̌̆- <*-gy-] “mille” [Nhl. 1909, 179].

(2) V. Blažek (1987 MS, 41; 1990, 41) equated Eg. md with CCh.: Higi gr. *mun- "10" [GT], ${ }^{82}$

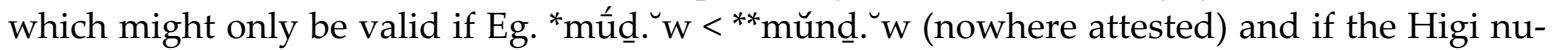
meral <**mung-. Mentioned also by G. Takács $(1994,217)$ in the context of further AA parallels. The etymology of Higi gr. *mun- "10" is uncertain..$^{83}$

(3) C. T. Hodge (kind p.c. on 4 September 1994) has not excluded a connection with PBrb. *tē-mihụay, pl. *tī-muhāḍ "100” [Prasse 1974, 406]. ${ }^{84}$ Since PBrb. *ḍ < PAA *̣̂̂ (cf. Mlt. 1991, 242; Takács 2006, 57-59, 62), the phonological correspondence of Eg. $\underline{\mathrm{d}} \sim$ PBrb. * $\mathrm{d}$ is regular, although PBrb. ${ }^{*}$-h- has no match in Eg. md. The etymology of the Berber numeral is obscure..$^{85}$

(4) V. Orel \& O. Stolbova $(1992,202)$ identified it with their ECh. * $\mathrm{m}^{\mathrm{w} a}$ ž- "10" (no reflexes mentioned), which is certainly a false reconstruction. This asterisk-form is solely based on the

${ }^{81}$ Attested in WCh.: Gerka (Yiwom) [IL] | Dera (Kanakuru) gum [Pls.] = gûm [Krf., Jng.], Tangale gbọmọ [Jng.] < * gwom- [GT] | (?) Tsagu wúúma [Skn. 1977, 34: < PCh. * g-m-] | Ngizim (< Hs.?) guma [IL] = gumə̀ [Krf.] = gúumà [Schuh], Bade (< Hs.?) gúmā [IL] = guumà [Krf.] (WCh.: also Pls. 1958, 85) || CCh.: Tera gwàn [Nwm. 1964, 36, \#10], Tera-Jara gwom [Nwm.], Hwona gumdị̀i kûm [Krf.], Boka kum [Krf.], Gabin kùm [Krf.], Ga’anda kum [Krf.] | Bura-Margi *kum- [GT] > Margi kūmụ́ [Hfm.] = kumu [Krf.], WMargi kuma kume [Krf.], Chibak kyme [IL] = kuma [Krf.], Bura kuma [Krf.], Wamdiu kumò [Krf.], Hildi kúmò [Krf.], Kilba kúmà [Krf.], Ngwahyi kuma [Krf.] | Fali-Kiria gwùm(ù) [Krf.], Fali-Jilbu gumù [Krf.], Fali-Mucella gùm [Krf.], Fali-Bwagira po-gumu [Krf.] | PMandara *gwamgV (?) [GT]: Dghwede gwàngá [Frick] = huwángá [IL], Ngweshe ùwángò [IL], Paduko žuma [Mch.] | Sukur úwân [IL] < * ${ }^{w}$ am (?) [GT] | Musgoy gup [Mch.], Daba gúb [Lienhard] | Musgu gum [Roeder] | PMasa * $\mathrm{g}^{\mathrm{w}} \mathrm{ub}-{ }^{* *} \mathrm{~g}^{\mathrm{w}} \mathrm{um}$ - (?) [GT]: Lame gwúbú [Krf.], Lame-Peve gwúḅ [Krf.], Zime-Batna gùp [Jng.] = gùbù [Scn.], Misme-Zime goub [Krf.] || ECh.: Mokilko kòòmá(t) [Jng.] (Ch.: Mkr. 1987, 43, 222; Ibr. 1990, 211-212; JI 1994 II 320-321).

${ }^{82}$ Attested in Higi mĕngĕ [Str.] = mw Baza mūnge [Lks. 1937, 113] = mùnə [Krf.], Higi-Kamale mùne [Krf.] vs. Kapsiki (= Kamale?) măng [Str.] = mən [WL] = mòn(á) [Brt.-Jng.], Higi-Ghye mùnəy [Krf.], Higi-Bana mònâ [WL] = mán [Brt.-Jng.], Higi-Futu mùni [Krf.], Fali-Gili mùn [Krf. 1972 MS] (Higi group data: Strümpell 1922-1923, 123; Wente-Lukas 1973, 7; Kraft 1981 II, 131, 141, 151, 161, 171, 191, \#10; Brt.-Jng. 1993, 131).

${ }^{83}$ Contrary to V. Blažek (1.c.), D. Ibriszimow (1990, 211-2) excluded a metathesis of PCh. *gum-/*gwam- "10" (above). Later, Blažek (1999, 251-3, §10; 1999, 47-49, §10) derived Higi gr. *mun- "10" from *mu-mg-, which might be etymologically identical with Agaw *mang- "many" [GT] || LECu. *mang- "many" [GT] ||| NOm.: Shinasha manga "heavy" [Lmb.] (discussed below). If this is correct, a remote kinship between Higi gr. *mun- with Eg. md is not impossible.

${ }^{84}$ Attested, a.o., in NBrb.: Nefusa te-mîți [Mtl.] = tə-miți [Lst.] = te-miti [Mrc.] || EBrb.: Sokna sənnət t-mîtin “deux cents” [Lst.] || WBrb.: Zenaga ta-māde (sic, -d-) “100” [Ncl. 1953, 206] || SBrb.: Ahaggar té-méḍé, pl. ti-maḍ "centaine" [Fcd. 1951-2, 1165] = ti-miḍi [Mtl.] = tə-miḍi [Lst.] = ti-mididi [Mrc.], ETawllemmet ti-miḍi [Bst.] = ETawllemmet \& Ayr te-meḍe Ayr ti-miḍa “1. centaine, 2. cent” [PAM 1998, 210; 2003, 524], Kel Ui ti-maḍi [Wlf.], Ghat či-miḍi “cent”, senat či-maḍ “deux cents” [Nhl. 1909, 138; Mrc.] (Brb.: Lst. 1931, 209; Mrc. 1933, 316; Wlf. 1954, 74).

85 (1) A. Klingenheben (apud Wölfel 1954, 75) and M. G. Mercier $(1933,316)$ erroneously explained it as a late borrowing from Ar. mi1-at- (!), which has rightly been excluded by Wölfel (l.c.). Surprisingly, this erroneous equation of the Berber numeral with Sem. *mi3-at- “1.000” has been recently adopted by E. Lipinski (1997, 291, §35.20). (2) F. Nicolas $(1953,206)$ combined it with WBrb.: Zenaga $\sqrt{ }$ md “finir, être fini”. (3) GT: cf. ECh.: Mokilko mèedá (f) “cent, centaine(s)” [Jng. 1990, 138], although Mokilko -d- vs. Brb. *-ḍ- seem irregular. 
isolated ECh.: Somray mož "zehn” [Nct. apud Lks. 1937, 80; Hfm. 1971, 9] = mwàž "10" [Jng. 1993 MS, 46; JI 1994 II, 321]. In theory, there could be a small chance that the Somrai form derives from an earlier ${ }^{*} \sqrt{\mathrm{m}}(\mathrm{w}) \mathrm{g}$, ${ }^{86}$ but this is surely not the case here due to the firm evidence for that Somray mož [Nct.] reflects ${ }^{*} \sqrt{ }$ mwd. ${ }^{87}$ The Afro-Asiatic background of the ECh. numeral is disputed. V. Blažek (1997, 18; 1999, 251-3, §10; 1999, 47-49, §10): < ${ }^{*} \mathrm{mVdV} \sim$ Eg. md and even

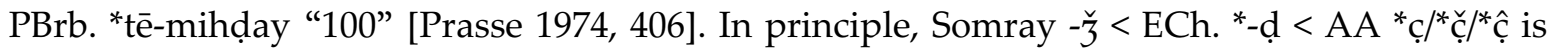
plausible,, 88 but we have insufficient evidence for * ${ }^{*}$ - in the East Chadic numeral against * $\mathrm{d}-$. Consequently, the available records provide hardly anything for equating Eg. and ECh. "10". G. Takács $(1999,136 ; 1999,202-203, \# 3.2)$ connected ECh. * $\sqrt{\mathrm{m}}(\mathrm{w}) \mathrm{d}$ with Sem. *ma?d- "many" [Djk.] || PBrb. impf. *ya-mduh, pf. *yu-mdah [Prasse 1975, 227] = *ə-mdu < * $\sqrt{\mathrm{md}}$ [h] "to complete” [GT] ||| SOm.: Ari mūda “all” [Bnd. 1994, 1158, \#1]. If this comparison proves to be valid, the East Chadic numeral can have nothing in common with Eg. md.

(5) G. Takács (1994, 217-218; 1995 MS, 5-6, \#7; 1996, 140, \#35; 1996, 443, \#7; 1999, 40, 50-51, 143) affiliated Eg. md "10" with ECu. *mig-/*mug- "fullness", *-mg- (prefix verb) "to fill” [Sasse 1979, 25] = *-meg- "to be full" [HL 1988, 127; Lmb. 1993, 353] = *-mig- "to be full" [Ehret 1997 MS, 196, \#1771] = *mVg- "many, full” [GT]. ${ }^{89}$ This Egypto-East Cushitic equation was as-

${ }^{86}$ Cf. perhaps ECh.: Somray Ráž̀̀ [Jng.] vs. Ndam yágā “to cut, chop” [Jng.] (ECh.: JI 1994 II, 99).

${ }^{87}$ Attested by its earlier record and its closest cognates listed by J. Lukas $(1937,74,87)$ and C. Hoffmann $(1971,9)$ : Somrai moid “10" [Adolf Friedrich] = moet [Gaudefroy-Demombynes], Dormo moid [Adolf Friedrich] | Gabri moid [Adolf Friedrich] = mwòž̀̀ [Caprile 1972 MS], Chire moodo “10” [Barth apud Lukas].

${ }^{88}$ Cf. ECh. *gaḍ-"cheek” [GT]: Kabalai kwaží [Cpr.] | Somray gàžé “cheek” [Jng.] | WDangla gàdùmò [Fédry] | Birgit gàdáyó [Jng.] (ECh.: JI 1994 II, 69) ||| SBrb.: Ahaggar ă-gy/ǵaz (-ġ- apud Fcd.) “joue” [Fcd. 1951-2, 491] ||| PCu. *gAc(с)- “лицо, лоб” [Dlg.] > Bed. gếdi “das Gesicht, Antlitz, Auge” vs. gwad gª́da gwaž gaž “Auge, Gesicht” [Rn. 1895, 89-90] = (also) gwaḍ, pl. gwaḍa “face, eye” [Dlg.] || NAgaw *gäc “face” [Apl.] = *gäç (?) [GT]: Bilin gäš, Hamir gaș, Qwara-Dembea gaš, Qemant gäš (NAgaw: Apl. 2006, 63) || ECu.* gaḍ- “jaw” [Apl., KM] || SCu.: WRift *gicē "forehead” [KM 2004, 117] < AA *Vgç/ç “cheek” [GT] (cf. Cohen 1947, \#197; Dolgopol'skij 1973, 297; HSED \#866 vs. \#914).

${ }^{89}$ Attested in Saho mag “anfüllen, voll machen" [Rn. 1890, 258-9] = mag "remplir" [Chn.] = -meg- (prefixed) "to fill" vs. mig-e "fullness" [Sasse] = -emmeg- "to be full” [HL] = emege (imp. amage) "to fill”, mig-e "fullness" [Vergari 2003, 78, 135], Saho-Assaorta mag-, pass. m-mag "essere molto, in molti, essere pieno" [CR 1913, 70] = meg- "to be numerous, full (быть многочисленным, полным)” [IS], Afar mag “anfüllen, voll machen” [Rn. 1886, 880] = -eng- [<*-emg-] "to fill” [Sasse] = -emmeg- "to be full” [HL] = enge "to fill” [PH 1985, 163], Afar-Tadjurah mog-o “many (много)" [IS] | Oromo mog-a "fullness", miž-ū [-̌̌̆- < *-g-] "full” [Sasse], Oromo-Waata magā-ta "many" [Strm. 1987, 362], Oromo-Bararetta imieke "full" [Flm.], Konso imako-ta "full" [Flm.] = immak- "to be full" [HL], Gidole innako-ta "full" [Flm.] = innak- "to be full" [HL], Gato imako-da "full" [Flm.] | OSomali *ammūg- "füllen" [Lmb. 1986, 437] > Somali mug "Fülle, Vollheit" [Rn. 1902, 288] = múg- "fullness" [Abr. 1964, 182], PBaiso \& Jiddu (sic) *3u/img- "full” [Ehret \& Nuuh Ali 1984, 229], Baiso mig-i "full” [Flm.] = mig-i “to be full” [HL] = Ramoga "many" [Sbr. 1994, 17] | Yaaku -mok [<*-mog], pl. -móže? “many, much" [Heine 1975, 130] (ECu.: Dlg. 1973, 256-257; Sasse 1979, 25; HL 1988, 127). In H.-J. Sasse’s (1979, 25) view, the Konso \& Gidole parallels (with -n-/-k-) "are obviously cognate, but display problematic correspondences", for which cf. NAgaw: Kemant imkuy "être abondant (le blé)" [CR 1912, 164] ||| WCh.: Tangale mụkmụk “somewhat full” [Jng. 1991, 121] || ECh.: EDangla mak “(idéophone d'accomplissement)" [Dbr.-Mnt. 1973, 192]. Do these parallels display traces of an AA root var. * $\sqrt{\mathrm{mk}}$ "full" [GT]? The relatedness of further possible parallels is still to be cleared, cf. LECu.: Rendille mig, pl. amíge, mimígé “strong, hard” [Heine 1976, 216, 220] = mīg (f) “Kraft, Macht” [Schlee 1978, 140, \#774] = míg-e "strength" [Oomen 1981, 72] = míg "strength, stiffness, tightness, heaviness, hardness, difficulty" [PG 1999, 224] ||| NOm. *magg- “1. full (?), 2. (hence) heavy” [GT]: Haruro māgg-āys "essere contento” (lit. "to be full”?) [CR 1937, 653] | Kefoid *magg- "to be heavy” [GT]: Kaffa mag- [Crl. 1951, 470] = magg- [Dlg.], Mocha màggi-yé "to be heavy", magg-o "heavy" [Lsl. 1959, 40], Sheko maggo "heavy" [Lmb.] (NOm.: LS 1997, 459 with semantically false comparanda) is semantically problematic. For the ECu.-NOm. comparison see Dlg. 1967, 9, \#7; 1973, 256-257; IS 1976, 41-42; Lmb. 1993, 111 (Cu.-Om. *-mVg- "to be full, heavy"). 
sessed by V. Blažek (1999, 251-3, §10; 1999, 47-49, §10) as the "most convincing" one of all the etymologies offered so far for Eg. md. The reflexes of ECu. *mig-/*mug- [Sasse] and NOm. *magg- "full" [GT] have often ${ }^{90}$ been compared with the Cushito-Omotic root containing an additional *-n-, cf. * $\sqrt{\mathrm{mng}}$ "much" [GT],91 on whose etymology there is no agreement in Cushitic studies..$^{92}$ The ultimate source of Eg. md and ECu.-NOm. ${ }^{*} \mathrm{mVg}$ - "1. many, 2. full, 3. heavy, 4. strong (?)" [GT] may be AA * $\sqrt{\mathrm{mg}}$ "1. big, 2. long, high" [GT]..$^{93}$ The semantic shift of Eg. md " 10 " as a "full, big" number is supported by a number of typological parallels. ${ }^{94}$ The

${ }^{90}$ Cf. Reinisch 1886, 880; 1890, 259; Conti Rossini 1913, 71; Leslau 1945, 163; 1979 III, 408-9; Illič-Svityč 1976, 41-42; Appleyard 1977, 26/68; Haberland-Lamberti 1988, 127; Lamberti 1993, 353; Lamberti-Sottile 1997, 459 (with semantically false comparanda).

${ }^{91}$ Cf. NAgaw: Qemant māngā "foule, quantité, multitude” [CR 1912, 230] = manga "multitude, crowd” [Lsl.] (Appleyard, p.c. on 20 April 2007: "without any doubt a loan from"Amharic mänga "herd, flock, crowd", which, in turn, is "obviously a loan from ECush.") || SAgaw *menči [-či < *-ki] "many” [GT]: Awngi ménč "many" [Htz./Bnd. 1971, 238, §50] = menךči (so!) [Flm./Bnd.] = ménči [Bnd. 1973 MS, 7, \#51] = ménč “many” [Apl. 1991, 8], Kunfal menči “many” [Birru \& Adal 1971, 102, \#50] = minči “many” [Bnd. 1970, 3, \#50] || LECu. *mang- "numerous” [GT] > Saho mang "viel, zahlreich werden, sich mehren" [Rn. 1890, 259, 269-270], Afar mang "angefüllt, voll werden/sein" [Rn. 1886, 880, 882] ||| NOm.: Shinasha-Bworo mang-á "heavy (schwer, gewichtig)" [Lmb. 1993, 111; 1993, 353].

92 The Saho-Afar stem *mang- has been explained by L. Reinisch $\left(1886,880\right.$ 1890, 259) from a pass. ${ }^{*} \mathrm{~m}$-ang

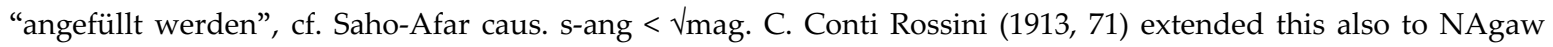
(Kemant) assuming a common PCu. *mag > *m-mag > *mamg > Kemant \& Saho-Afar mang-. G. Banti (p.c., 19 April 2007), in turn, sees in the LECu. forms a prefix ma- ("the form is like mabla 'seeing'" in Saho-Afar). D. Appleyard (p.c., 20 April 2007) shares the same view: "mamga is certainly the more 'archaic' in so far as it is more transparently the nominal prefix ma- + the verbal root-mg-, i.e. PEC *mig-/mug- etc. 'be full' ... it seems to me quite reasonable to build a new 'root' on the basis of a nominal derivation *ma-m[V]g-; partial reduplication of the $\mathrm{C}_{1} \mathrm{VC}_{1} \mathrm{VC}_{2}-$ type seems less likely to me". The Cu. stem was probably borrowed into Eth.-Sem.: Gafat mängä, Amh. mänga, Gurage-Soddo mänga "herd, flock" (ES: Leslau 1945, 163; 1979 III, 408-9; Appleyard 1977, 26/68 with less likely alternative Semitic etymologies). For reasons outlined here, the comparison of Cu.-Om. *mang- with CCh.: PHigi *mun- "10" [GT] (above) seems at the moment rather unlikely.

${ }^{93}$ Attested in Sem.: Akk. magāgu (also maqāqu) “(weg)spreizen” [AHW 574] ||| NOm.: Ometo *mēg- "col” [GT]: Wolayta \& Dawro (Kullo) meg-uwa, Gofa \& Gamu \& Dorze mēg-o | Shinasha mēg-o (NOm.: Alm. 1993 MS, 8, \#202b) ||| CCh. *Vmg... "long (of stick)” [JS 1981, 169B 1 : Musgu masc. mógwa, fem. muguíí, pl. moggwáákai "lang, hoch" [Krause apud Müller 1886, 401] = mógoa [Rohlfs] = mogó "lang” [Overweg] = ana-mogó "it is big” [Rohlfs] = mogó “groß” [Roeder] = mugwi "hoch" [Décorse] = mógo "groß” [Lks.], Musgu-Pus mogo (m), mogwi (f), pl. mogokai "hoch” [MB 1972 MS, 4] = mogo (masc.), muguwiy (fem.) "long” [Trn. 1991, 106], Musgu-Girvidik mógó (m), mógwí (f), pl. mógwáy "hoch” [MB 1972 MS, 4] = mogo(m) "lang” [MB 1972-73, 70] (Musgu: Lukas 1937, 141; 1941, 68) || ECh.: Tumak māgán “nombreux”, cf. māg “être capable, pouvoir, beaucoup” [Cpr. 1975, 81]. For the AA etymology see IS 1976, 41-42; HSED \#1704. Cf. also SSem. *لVmgn (root ext. *-n?) “very (much)” [GT]: Jibbali mékən “much, many, a lot of” [Jns. 1981, 170], Mehri maken [-k- < *g-] "beaucoup, très” [Lsl.] = mēken [Jahn] = mēkən "much, many, a lot of" [Jns. 1987, 264] || Amh. magan "très large” [Lsl.] = mägän "1. very large, unusually or strangely large (size), portentous, 3. type of long shield used by a fully-grown man” [Kane 1990, 343] (Sem.: Lsl. 1931-34, 35).

${ }^{44}$ Cf. (1) PCh. * "gwam- "10” [Nwm. 1977, 32] WCh.: Angas-Sura *gam “to fill” [GT] (Angas-Sura data: Hfm. 1975 MS, 24, \#215; Stl. 1972, 181; 1977, 154, \#65; 1987, 217, \#676; GT 2004, 121) | Bole-Tangale *(n)gamu “to fill, be full” [Schuh 1984, 216] = *(n)-gwam [GT] | NBauchi *g-m- "to gather, join, meet” [Skn. 1977, 23] (WCh. data: Stl. 1987, 217-8; JI 1994 II, 156) || Sem. *Vgmm “völlig sein/machen” [GB] > Hbr. gam “zusamt, steigernd” [GB 143] | Ar. ğamma I "1. être riche, 2. être abondant, se remplir de nouveau d'eau, 3. être comble" etc., ğamm- "1. abondant, exubérant, 2. complet, 4. (mesure) comble” [BK I 321-2] (for further Sem. cognates see Hodge 1971, 42; Zbr. 1971, \#58; MacDonald 1963-65, 75; WUS \#664; Vycichl 1987, 114) ||| Eg. ngmgm (prefix n-) “sich versammeln” (XVIII., Derchain-Urtel 1973, 39-40 contra Wb II 349, 15) ||| HECu. *gum3a “all” [Hds. 1989, 411] ||| NOm.: Oyda gāma "much, many" [Dlg. 1973, 78]. For the Ar.-WCh. comparison: Stl. 1987, 218; OS 1990, 80, \#55; HSED \#888. Or 
same is to be observed about Afro-Asiatic "hundred",95 "thousand", 96 "ten thousand", 97 and "hundred thousand". 98

\section{Summary}

The results of the etymological analyses presented above lead us to the following table. Note that $(+)$ in brackets signifies an existing, albeit indirect, correspondence of an Egyptian numeral, displaying some deviation in form. E.g., North Afro-Asiatic "two" ( ${ }^{*}$ čn) is ultimately related to South Cushitic and Chadic "two" ( $\sqrt{ }$ čr), but only as ancient heteroclitic root varieties in Proto-Afro-Asiatic.

\begin{tabular}{|c|c|c|c|c|c|}
\hline Eg. & Sem. & Brb. & $\mathrm{Cu}$. & Om. & Ch. \\
\hline$\overline{V_{W S}} " 1 "$ & + & $+?$ & - & - & - \\
\hline$\sqrt{s n}_{\mathrm{sn}}$ "2" & + & + & $(+)$ & - & $(+)$ \\
\hline$\sqrt{\text { hmt }}$ “3” & - & - & + & + & + \\
\hline$V_{\mathrm{fd}}$ "4" & - & - & - & + & + \\
\hline$\sqrt{d j}$ “5” & $(+)$ & - & - & - & - \\
\hline لvsrs "6" & + & + & - & $(+)$ & $(+)$ \\
\hline$V_{\text {sfh }}$ “7” & + & + & $+? ? ?$ & + & + \\
\hline$\sqrt{h m n} " 8$ " & + & $(+?)$ & $(+)$ & $(+)$ & - \\
\hline Vpsd “9” & + & $+?$ & - & - & $+?$ \\
\hline$\sqrt{\mathrm{md}}$ " $10 "$ & - & - & $(+)$ & $(+)$ & + \\
\hline
\end{tabular}

cf. (2) Sem. * \{aŝar- "10" [Dlg. 1986, 79, \#14] || WCh.: Angas-Sura *șār "ten” [GT] (Angas-Sura data: Jng. 1965, 182; Hfm. 1975 MS, 20, \#93; Stl. 1972, 182; 1977, 157, \#188; JI 1994 II, 320; Takács 2004, 334-5) ||| Eg. ؟š3 [< *\{šr] "viel (sein)" (OK, Wb I 228, 8-26). For the Eg.-Sem.-Angas-Sura etymology: Trb. 1902, 199; Ember 1917, 88, \#135; ESS §3.b.4; Alb. 1918, 92; 1931, 150; Vrg. 1945, 128, §1.c.8; Cohen 1947, \#47; Hodge 1976, 15, \#165; OS 1988, 82; Blv. 1989, 15; Mlt.-Stl. 1990, 65.

${ }^{95}$ Cf. NOm.: Kullo (Dawaro) tet-a "100" [CR 1913, 410] || Eg. twt "versammeln, versammelt sein" (PT, Wb V 259-260) || (?) WCh. *tVt- "to gather" [OS] (for the Eg.-PWCh. etymology see OS 1992, 195). Or cf. Sem. * Vrbb "big" > Ebl. rib(b)a or ribab "10.000” [Brugnatelli 1984, 86-87; Gordon 1988, 261] || Ug. rbt, Hbr. robabā, Aram. ribbabtā “10.000” (Canaanite: Ember 1917, 87; WUS \#2481).

${ }^{96}$ Cf. ECu. *kum- "1.000" [Sasse 1979, 12, 25; 1982, 120] || SCu. *kuma "1.000" [Ehret 1987, 30] || NOm. *kum“1.000" [GT] Eg. km "vollständig machen, vollenden” (MK, Wb V 128-130) || EBrb.: Siwa kôm, koma "tout, beaucoup" [Lst. 1931, 304] = "all, whole" [Mlt. 1991, 250] || LECu.: Baiso kamogani "much, many" [Ehret] || NOm.: POmeto *kum- "to be full" [GT] (NOm. data: LS 1997, 412).

${ }^{97}$ Cf. Sem. * $\sqrt{ }$ rbb "big" > Ebl. rib(b)a or ribab "10.000" [Brugnatelli 1984, 86-87; Gordon 1988, 261] || Ug. rbt | Hbr. rəbabā, Aram. ribbabtā "10.000" (Canaanite: Ember 1917, 87; WUS \#2481). Or perhaps Eg. d. db؟ “10.000” (I-, Wb V 365-366) NOm.: She geba "many" [Flm.] || SOm.: Hamer \& Karo gezbi [Flm.: error for *geḅi?] "big" [Flm.] (Om.: Flm. 1976, 317) || ECh.: WDangla góóbée “remplir un récipient (en l'immergent dans l'eau)” [Fédry 1971, 329]. As noted by W. Vycichl $(1934,80)$, the comparison of Eg. dbS with WCh.: Hausa dubu "1.000" (suggested by N. Skinner 1981, 187-8, \#105 pace Barth) is excluded. For an alternative etymology of Eg. db see Takács 1997, 217, \#9.

${ }^{98}$ Cf. Eg. h.̣n [< *hfl] "100.000" (I-, Wb III 74, 1) Sem.: Ar. ḥafala I "reichlich vorhanden sein", V "sich in grosser Zahl versammeln”, hafl- "Menge”, hafîl- "zahlreich" [Vrg., Vcl.]. For Eg.-Ar. see Sethe 1916, 13-14; Ember 1917, 87, \#135; ESS §9.a.7; Albright 1918, 93; Vergote 1945, 136, §9.b.26; Cohen 1947, \#111; Vycichl 1958, 377; Loprieno 1986, 1310. For a different (less convincing) etymology of Eg. hfn see Holma 1919, 41; Hodge 1976, 12, \#49; 1990, 370. 


\section{Conclusion}

The first two, i.e., the most elementary and primary numerals, are evidently North AfroAsiatic with no match in the southern block of the phylum, which clearly suggests an aboriginal northern affiliation of Egyptian just like the common North Afro-Asiatic apophony penetrating Semitic, Egyptian, and Berber morphology.

But the obvious South Afro-Asiatic nature of Egyptian "three" and "four" seems to testify to later renewed ties of Proto-Egyptian with the southern block, i.e., a secondary areal cohabitation, which agrees quite neatly with the lack of the prefix conjugation, an isogloss in the whole phylum shared by both Egyptian and Chadic grammar, which is paralleled by the undeniable domination of South Afro-Asiatic items in the overwhelming majority of Egyptian anatomical terminology, let alone the multitude of exclusively Egypto-Chadic lexical isoglosses.

Egyptian "five" must be an Egyptian innovation based on an extinct Eg. ${ }^{* j d}$ "hand" = Sem. *yad- "hand" as a nisbe form, which was to render "5" only on the Egyptian side. This innovation was either very late having ousted Semito-Berber $* \sqrt{h m s}$ " 5 ", or was simply much earlier than the latter. The former scenario seems more likely in the light of the separation of Egyptian from the Northern Afro-Asiatic block earlier than that of Semitic and Berber (cf. Takács 2015).

Once again the set of Egyptian numerals from "six" to "nine" comprises Semitic (and Berber) words (only "seven" seems to be sporadically attested in South Afro-Asiatic too), but, for some suspicious reason, all of them suffer from some fundamental phonological irregularity in Egyptian atypical of genetically inherited Egypto-Semitic cognates, cf. Eg. -r- vs. Sem. *-d- in "6", Eg. -fh vs. Sem. *-bS in “7”, Eg. h- vs. Sem. *t- in “8”, Eg. p-/-d vs. Sem. *t-/*-\$ in "9”. Does this puzzle speak for a borrowed and not inherited nature of these higher numerals during a later secondary areal contact with Semitic, perhaps in the neolithic Nile valley (5 $5^{\text {th }}$ mill. BC?)?

Finally, Egyptian "ten" is a South Afro-Asiatic word exclusively attested in Chadic (although the underlying verbal root is Common Afro-Asiatic), which may indicate a common decimal system created (together with SAA "3" and " 4 ") during the above mentioned secondary areal cohabitation of Proto-Egyptian and Chadic (or South Afro-Asiatic).

\section{Abbreviations of languages}

(A): Akhmimic, AA: Afro-Asiatic, Akk.: Akkadian, Ar.: Arabic, Aram.: Aramaic, (B): Bohairic, BD: Book of the Dead, Bed.: Bed'awye, Brb.: Berber, Ch.: Chadic, CCh.: Central Chadic, CT: coffin texts, Cu.: Cushitic, ECh.: East Chadic, ECu.: East Cushitic, E: East(ern), Eg.: Egyptian, EWlmt.: East Tawllemmet, (F): Fayyumic, GR: Greek (Ptolemaic) and Roman Period, GW: syllabic or group-writing, Hbr.: Hebrew, HECu.: Highland East Cushitic, IMP: Intermediate Period, JAram.: Jewish Aramaic, (L): Lycopolitan (or Subakhmimic), LECu.: Lowland East Cushitic, Lit.: literary texts, LP: Late Period, M: Middle, Mag.: magical texts, MK: Middle Kingdom, N: North, NBch.: North Bauchi, NBrb.: North Berber, NK: New Kingdom, NOm.: North Omotic, OEg.: Old Egyptian, OK: Old Kingdom, Om.: Omotic, OT: Old Testament, PB: post-Biblical, PCh.: Proto-Chadic, PCu.: Proto-Cushitic, PT: pyramid texts, S: South(ern), (S): Sahidic, SBrb.: South Berber, Sem.: Semitic, W: West(ern), WBrb.: West Berber, WCh.: West Chadic, WSem.: West Semitic.

\section{Abbreviations of authors}

Abr.: Abraham, Ajl.: Ajello, Alb.: Albright, Alm.: Alemayehu, Apl.: Appleyard, BA: Birru \& Adal, BK: Biberstein \& Kazimirsky, Blv.: Belova, Blz.: Blažek, Bmh.: Bomhard, Bnd.: Bender, Brg.: Bargery, Brk.: Brockelmann, Brt.: Barreteau, Cpr.: Caprile, CR: Conti Rossini, Crl.: Cerulli, Ctc.: Caïtucoli, Dbr.-Mnt.: Djibrine \& Montgolfier, Djk.: D'jakonov, Dlg.: Dolgopol'skij, Dlt.: Dallet, Drnb.: Doornbos, Dst.: Destaing, Ehr.. Ehret, Fcd.: Foucauld, Fdr.: 
Fédry, Flk.: Foulkes, Flm.: Fleming, Frj.: Frajzyngier, Frz.: Fronzaroli, Ftp.: Fitzpatrick, GB: Gesenius \& Buhl, Gcl.: Gochal, Grb.: Greenberg, GT: Takács, Hds.: Hudson, Hfm.: Hoffmann, HL: Haberland \& Lamberti, Hlw.: Hellwig, Hmb.: Homburger, HRV: Heine \& Rottland \& Voßen, Hyw.: Hayward, IS: Illič-Svityč, JA: Jungraithmayr \& Adams, JI: Jungraithmayr \& Ibriszimow, Jng.: Jungraithmayr, Jns.: Johnstone, Jst.: Justinard, KB: Koehler \& Baumgartner, KM: Kießling \& Mous, Kmr.: Kammerzell, Krf.: Kraft, Ksm.: Kossmann, Lks.: Lukas, Lmb.: Lamberti, Lnf.: Lanfry, LS: Lamberti \& Sottile, Lsl.: Leslau, Lst.: Laoust, MB: Meyer-Bahlburg, Mch.: Mouchet, Mkr.: Mukarovsky, Mlt.: Militarev, Mnh.: Meinhof, MQK: Mous \& Qorro \& Kießling, Mrc.: Mercier, Mrn.: Moreno, MSkn.: M. Skinner, Mts.: Matsushita, Ncl.: Nicolas, Nct.: Nachtigal, Nhl.: Nehlil, NM: Newman \& Ma, Ntg.: Netting, Nwm.: Newman, Old.: Ol'derogge, OS: Orel \& Stolbova, PAM: Prasse, Alojaly, Mohamed, PB: PlazikowskyBrauner, PG: Pillinger \& Galboran, PH: Parker \& Hayward, Pls.: Pilszczikowa, Prd.: Paradisi, Prs.: Prasse, RK: Reutt \& Kogan, Rn.: Reinisch, Rns.: Renisio, Rpr.: Roper, Rsg.: Rossing, Rsl.: Rössler, Sbr.: Siebert, Scn.: Sachnine, Skn.: N. Skinner, Smz.: Shimizu, Snk.: Schenkel, Spg.: Spiegelberg, Srl.: Sirlinger, SSL: Simeone-Senelle \& Lonnet, Stl.: Stolbova, Str.: Strümpell, Strm.: Stroomer, Sts.: Starostin, TC: Taïne-Cheikh, Tf.: Taïfi, Trb.: Trombetti, Trn.: Tourneux, TSL: Tourneux \& Seignobos \& Lafarge, Vcl.: Vycichl, Vrg.: Vergote, Wdk.: Wedekind, Wlf.: Wölfel, WP: Walde \& Pokorny, Wst.: Westendorf, Wtl.: Whiteley, Zbr.: Zaborski, Zhl.: Zyhlarz, Zvd.: Zavadovskij.

\section{References}

Abel, Hans. 1933-4. Nubisch-ägyptisches Sprachgut. Zeitschrift für Eingeborenen-Sprachen 24: 303-306.

Abès, Mohamed. 1916. Manuel de berbère marocain. (Place not indicated), (publisher not indicated).

Abraham, R. C. 1962. Dictionary of the Hausa Language. ${ }^{2}$ London, University of London Press.

Abraham, R. C. 1964. Somali-English Dictionary. ${ }^{2}$ London, University of London Press Ltd.

A ̈̈G = Edel, Elmar. 1955. Altägyptische Grammatik. Roma, Pontificium Institutum Biblicum.

AHW = Soden, Wolfram von. 1965-1981. Akkadisches Handwörterbuch. I-III. Wiesbaden, Otto Harrassowitz.

Albright, William Foxwell. 1918. Notes on Egypto-Semitic Etymology. I. American Journal of Semitic Languages and Literatures 34/2, 81-98.

Albright, William Foxwell. 1918. Notes on Egypto-Semitic Etymology. II. American Journal of Semitic Languages and Literatures 34/4, 215-255.

Albright, William Foxwell. 1923. The Principles of Egyptian Phonological Development. Recueil de Travaux Relatifs à la Philologie et à l'Archéologie Égyptiennes et Assyriennes 40, 64-70.

Albright, William Foxwell. 1923. The Etymology of Egyptian ḥm.t "Woman". Recueil de Travaux Relatifs à la Philologie et à l'Archéologie Égyptiennes et Assyriennes 40, 71-72.

Albright, William Foxwell. 1926. The New Cuneiform Vocabulary of Egyptian Words. Journal of Egyptian Archaeology 12, 186-190.

Albright, William Foxwell. 1927. Notes on Egypto-Semitic Etymology. III. Journal of the American Oriental Society 47, 198-237.

Albright, William Foxwell. 1931. Review of Ember, A.: Egypto-Semitic Studies. Language 7/2, 147-150.

Alemayehu, Abebe. 1993. Ometo Dialect Survey - A Pilot Survey Report. Survey of Little-Known Languages of Ethiopia (S.L.L.E.) Reports 4, 1-10.

Alio, Khalil. 2004. Préliminaires à une étude de la langue kajakse d'Am-Dam, de Toram du Salamaat, d'ubi du Guéra et de masmaje du Batha-est. In: Takács, G. (ed.): Egyptian and Semito-Hamitic (Afro-Asiatic) Studies in Memoriam Werner Vycichl. Leiden, E. J. Brill. Pp. 229-285.

Allan, Edward J. 1976. Dizi. In: Bender, M. L. (ed.): The Non-Semitic Languages of Ethiopia. East Lansing, Michigan State University. Pp. 377-392.

Almkvist, Herman. 1885. Die Bischari-Sprache Tū-Bedāwie in Nordost-Afrika. Zweiter Band: Bischari-deutsches und deutsch-bischarisches Wörterbuch. Uppsala, Akademische Buchdruckerei.

Appleyard, David. 1991. The Vowel Systems of Agaw: Reconstruction and Historical Inferences. In: Mukarovsky, Hans G. (ed.): Proceedings of the Fifth International Hamito-Semitic Congress. Band II. Wien, Afro-Pub. Pp. 13-28.

Appleyard, David. 1991. A Comparative Agaw Wordlist. MS. London, 13 p.

Appleyard, David. 2006. A Comparative Dictionary of the Agaw Languages. Köln, Rüdiger Köppe Verlag.

ÄWb I = Hannig, Rainer. 2003. Ägyptisches Wörterbuch I. Altes Reich und Erste Zwischenzeit. Hannig-Lexica 4. Mainz am Rhein, Verlag Philipp von Zabern. 
ÄWb II = Hannig, Rainer. 2006. Ägyptisches Wörterbuch II. Mittleres Reich und Zweite Zwischenzeit. I-II. HannigLexica 5. Mainz am Rhein, Verlag Philipp von Zabern.

Bargery, G. P. 1934. A Hausa-English Dictionary and English-Hausa Vocabulary Compiled for the Government of Nigeria. London, Oxford University Press, Humphrey Milford.

Barreteau, Daniel. 1988. Description du mofu-gudur. Langue de la famille tchadique parlée au Cameroun. Livre II. Lexique. Paris, Éditions de l'ORSTOM.

Barreteau, Daniel \& Jungraithmayr, Herrmann. 1993. Calculs lexicostatistiques et glottochronologiques sur les langues tchadiques. In: Barreteau, Daniel \& Graffenried, Ch. von (éds.): Datation et chronologie dans le bassin du Lac Tchad (Dating and Chronology in the Lake Chad Basin). Paris, Éditions de l'ORSTOM. Pp. 103140.

Barton, George Aaron. 1934. Semitic and Hamitic Origins. Social and Religious. Philadelphia, University of Pennsylvania Press.

Behnk, Frida. 1927. Lexikalische Beiträge zur ägyptisch-semitischen Sprachvergleichung. Zeitschrift für Ägyptische Sprache 62, 80-83.

Behnk, Frida. 1928. Über die Beziehungen des Ägyptischen zu den hamitischen Sprachen. Zeitschrift der Deutschen Morgenländischen Gesellschaft 82, 136-141.

Belova, Anna Grigor'evna. 1989. Refleksy semitskih sibiljantov v drevneegipetskom. Meroé 4, 9-21.

Bender, Marvin Lionel. 1970. Kunfel 100-Item Basic Word List (Investigator: T. Birru, Z. Adal). MS. Carbondale, Illinois. $6 \mathrm{p}$.

Bender, Marvin Lionel. 1971. The Languages of Ethiopia. A New Lexicostatistic Classification and Some Problems of Diffusion. Anthropological Linguistics 13/5, 165-288.

Bender, Marvin Lionel. 1973. Awiya Basic Elicitation Form for Linguistic Fieldwork in Ethiopia (Investigator: Robert Hetzron). MS. Carbondale, Illinois. 12 p.

Bender, Marvin Lionel. 1974. Word and Phrase List for Fieldwork in Western Ethiopia. Chara I. MS.

Bender, Marvin Lionel. 1975. Omotic: A New Afroasiatic Language Family. Carbondale, Illinois, Southern Illinois University.

Bender, Marvin Lionel. 1983. Remnant Languages of Ethiopia and Sudan. In: Bender, Marvin Lionel (ed.): NiloSaharan Language Studies. East Lansing, Michigan, Michigan State University. Pp. 336-354.

Bender, Marvin Lionel. 1994. Aroid (South Omotic) Lexicon. Afrikanistische Arbeitspapiere 38, 133-162.

Bender, Marvin Lionel. 1994. The Mystery Languages of Ethiopia. In: Marcus, Harold (ed.): New Trends in Ethiopian Studies. Vol. 1. Lawrenceville, Red Sea Press. Pp. 1153-1174.

Biberstein Kazimirski, A. de. 1860. Dictionnaire arabe-français. Vol. I-II. Paris, Maisonneuve \& Co. Editeurs.

Birru, Teqebba; Adal, Zena; Cowley, R. W. 1971. The Kunfäl People and Their Language. Journal of Ethiopian Studies 9/2, 99-106.

Blachère, Régis; Chouémi, Moustafa; Denizeau, Claude; Pellat, Charles (à partir de de la page 2155). 1967-1976. Dictionnaire arabe-français-anglais (Langue classique et moderne). Tome I-III. Paris, Maisonneuve et Larose.

Black, Paul D. 1974. Lowland East Cushitic: Subgrouping and Reconstruction. Ph.D. dissertation. Yale University.

Blažek, Václav. 1987. Afrasian Numerals. MS. Paper prepared for the 5th International Hamito-Semitic Congress, Vienna.

Blažek, Václav. 1989. Lexica Nostratica. Addenda et Corrigenda I. Archív Orientální 57, 201-210.

Blažek, Václav. 1989. A New Contribution to Comparative-Historical Afrasian Linguistics. Asian and African Studies 24, 203-222.

Blažek, Václav. 1990. A Comparative-Etymological Approach to Afrasian Numerals. In: Mukarovsky, Hans G. (ed.): Proceedings of the Fifth International Hamito-Semitic Congress. Vol. I. Vienna, Afro-Pub. Pp. 29-44.

Blažek, Václav. 1991. The Fifth International Hamito-Semitic Congress (Vienna, 28 September - 2 October 1987). Asian and African Studies 26, 201-210.

Blažek, Václav. 1993. The Microsystem of Cushitic Numerals. MS. Paper presented at the 23rd CALL, Leiden, September $11 \mathrm{p}$.

Blažek, Václav. 1997. Indo-European "Seven”. In: Hegedüs, Irén; Michalove, Peter A.; Manaster Ramer, Alexis (eds.): Indo-European, Nostratic, and Beyond: Festschrift for Vitalij V. Shevoroshkin. Washington D.C., Institute for the Study of Man. Pp. 9-29.

Blažek, Václav. 1999. Numerals. Comparative-Etymological Analyses and Their Implications. Brno, Masarykova Univerzita v Brně. 
Blažek, Václav. 1999. Egyptian Numerals. In: Lamberti, Marcello \& Tonelli, Livia (eds.): Afroasiatica Tergestina. Papers from the $9^{\text {th }}$ Italian Meeting of Afro-Asiatic (Hamito-Semitic) Linguistics, Trieste, April 23-24, 1998. Contributi presentati al 90 Incontro di Linguistica Afroasiatica (Camito-Semitica), Trieste, 23-24 Aprile 1998. Padova, Unipress. Pp. 229-264.

Bomhard, Allan R. 1988. Peresmotr indoevropejsko-semitskoj gipotezy. In: Novoe v zarubežnoj lingvistike. Vypusk XXI. Novoe v sovremennoj indoevropistike. Moskva, Progress. Pp. 433-450.

Brauner 1950, cf. Plazikowsky-Brauner.

Bravmann, Max M. 1977. Studies in Semitic Philology. Leiden, E.J. Brill.

Brockelmann, Carl. 1907/1908. Grundriss der vergleichenden Grammatik der semitischen Sprachen. I. Band: Laut- und Formenlehre. Berlin, Verlag von Reuther \& Reichardt.

Brugnatelli, Vermondo. 1982. Questioni di morfologia e sintassi dei numerali semitici. Firenze, Publicazioni della Facultà di Lettre e Filosofia dell’Università di Milano.

Brugnatelli, Vermondo. 1984. Some Remarks on Semitic Numerals and the Ebla Texts. In: Fronzaroli, P. (ed.): Studies on the Language of Ebla. Firenze, Istituto di Linguistica e di Lingue Orientali, Università di Firenze. Pp. 8599.

Caïtucoli, Claude. 1983. Lexique masa. Paris, Agence de Coopération Culturelle et Technique.

Caprile, Jean-Pierre. 1975. Lexique tumak-français (Tchad). Berlin, Verlag von Dietrich Reimer.

Cerulli, Enrico. 1929. Note su alcune popolazioni sidāmā dell'Abissinia meridionale II: i Sidama dell'Omo. In: $R i$ vista degli Studi Orientali 12, 1-69.

Cerulli, Enrico. 1936. Studi etiopici. I. La lingua e la storia di Harar. Roma, Istituto per l'Oriente.

Cerulli, Enrico. 1938. Studi etiopici. III. Il linguaggio dei Giangerò ed alcune lingue Sidama dell'Omo (Basketo, Ciara, Zaissè). Roma, Istituto per l'Oriente.

Cerulli, Enrico. 1942. Il linguaggio degli Amar Cocche e quello degli Arbore nella zona del lago Stefania. In: Rassegna di Studi Etiopici 2/3, 260-272.

Cerulli, Enrico. 1951. Studi etiopici. IV. La lingua caffina. Roma, Istituto per l'Oriente.

Chiomio, G. 1938. Brevi appunti di lingua uollamo (A.O.I.): Grammatica e dizionario. Torino, Istituto Missione Consolata.

Cohen, Marcel. 1947. Essai comparatif sur le vocabulaire et la phonétique du chamito-sémitique. Paris, Librairie Ancienne Honore Champion.

Conti, Giovanni. 1978. Rapporti tra egiziano e semitico nel lessico egiziano dell'agricoltura. Firenze, Istituto di Linguistica e di Lingue Orientali, Università di Firenze.

Conti Rossini, Carlo. 1912. La langue des Kemant en Abyssinie. Wien, Alfred Hölder.

Conti Rossini, Carlo. 1913., Schizzo del dialetto saho dell'alta Assaorta in Eritrea. Roma, Tipografia della R. Accademia dei Lincei.

Conti Rossini, Carlo. 1913. Studi su populazioni dell'Etiopia. Rivista degli Studi Orientali 6, 365-426.

Conti Rossini, Carlo. 1925. Sui linguaggi dei Naa e dei Ghimirra (Sce) nell'Etiopia Meridionale. Rendiconti della Reale Accademia dei Lincei, Classe di Scienze morali, storiche e filologiche, ser. VI, vol. 1, 512-636.

Conti Rossini, Carlo. 1927. Sui linguaggi parlati a nord dei Laghi Rodolfo e Stefania. In: Festschrift C. Meinhof. Sprachwissenschaftliche und andere Studien. Hamburg, Pp. 247-255.

Conti Rossini, Carlo. 1937. Contributi per la conoscenza della lingua Haruro (Isole del Lago Margherita). Rendiconti della Reale Accademia Nazionale dei Lincei, Classe di Scienze morali, storiche e filologiche, Ser. VI, vol. XII, fasc. 7-10, 621-679.

CT = Buck, Adrian de. 1935-1961. The Egyptian Coffin Texts. Vol. I-VII. Chicago, The University of Chicago Press.

Dallet, le P. Jean-Marie. 1982. Dictionnaire qabyle-français. Parler des At Mangellat (Algerie). Paris, SELAF (Société d'études linguistiques et anthropologiques de France).

DCT = Molen, Rami van der. 2000. A Hieroglyphic Dictionary of Egyptian Coffin Texts. Leiden, E.J. Brill.

DED = Burrow, Thomas; Emeneau, Murray Barnson. 1961. A Dravidian Etymological Dictionary. Oxford, Clarendon Press.

DELC = Vycichl, Werner. 1983. Dictionnaire étymologique de la langue copte. Leuven, Peeters.

Derchain-Urtel, Maria Theresia. 1973. Das n- Präfix im Ägyptischen. Göttinger Miszellen 6, 39-54.

Destaing, Edmond. 1938. Vocabulaire français-berbère (tachelhit du Soûs). Paris, Éditions Ernest Leroux.

DG = Erichsen, Wolja. 1954. Demotisches Glossar. Koppenhagen, Ejnar Munksgaard.

D’jakonov, Igor' Mihajlovič. 1965. Semitohamitskie jazyki. Opyt klassifikacii. Moskva, Nauka. 
Diakonoff, Igor. 1974. Hamito-Semitic Languages. In: Encyclopaedia Britannica. ${ }^{15}$ Macropaedia. Volume 22. Chicago, The University of Chicago Press. Pp. 740-748.

D’jakonov, Igor' Mihajlovič. 1986. Obščeafrazijskie imennye kategorii. In: Pis'mennye pamjatniki i problemy istorii kul'tury narodov Vostoka. XIX godičnaja naučnaja sessija LO IV AN SSSR. Moskva, Nauka. Pp. 47-62.

Diakonoff, Igor. 1988. Afrasian Languages. Moscow, Nauka.

Djibrine, Bada Adoum Zaid; Montgolfier, Paul de (et beaucoup d'autres). Around 1973 (publication year deduced by G. Takács). Vocabulaire dangaléat. Kawo dayla. Place not indicated, publisher not indicated.

DLE = Lesko, Leonard H. 1982-9. A Dictionary of Late Egyptian. Vol. I-IV. Berkeley, B.C. Scribe Publications.

Dolgopol'skij, Aron Borisovič. 1966. Materialy po sravnitel'no-istoričeskoj fonetike kušitskih jazykov. Gubnye i dental'nye smyčnye v načal'nom položenii. In: Uspenskij, B. A. (ed.): Jazyki Afriki. Voprosy struktury, istorii $i$ tipologii. Moskva, Nauka. Pp. 35-88.

Dolgopolski, Aharon. 1967. La permutation des *m et ${ }^{*} \mathrm{~b}$ initiaux dans les racines couchitiques. In: Il Congrès International des Africanistes. Communications de la délégation de l’URSS. Moscou, Nauka. Pp. 3-17.

Dolgopol'skij, Aron Borisovič. 1967. Nostratičeskie osnovy s sočetaniem šumnyh soglasnyh. In: Étimologija, 296313.

Dolgopol'skij, Aron Borisovič. 1973. Sravnitel'no-istoričeskaja fonetika kušitskih jazykov. Moskva, Nauka.

Dolgopolsky, Aharon. 1983. Semitic and East Cushitic. Sound Correspondences and Cognate Sets. In: Segert, Stanislav \& Bodrogligeti, A. J. E. (eds.): Ethiopian Studies Dedicated to Wolf Leslau. Wiesbaden, Otto Harrassowitz. Pp. 123-142.

Dolgopolsky, Aharon. 1986. Semitic Nomina Segolata in Ethiopic. In: Goldenberg, G. (ed.): Ethiopian Studies: Proceedings of the Sixth International Conference, Tel Aviv, April 1980. Rotterdam, Boston, Balkema. Pp. 71-90.

Dolgopolsky, Aharon. 1988. Semitic and East Cushitic: Word-Initial Laryngeals. In: Taddese, B. (ed.): Proceedings of the Eighth International Conference of Ethiopian Studies, University of Addis Ababa, 1984. Volume 1. Addis Ababa, Institute of Ethiopian Studies, Addis Ababa. Pp. 629-637.

Dombrowski, Franz Amadeus \& Dombrowski, Bruno W. W. 1991. Numerals and Numeral Systems in the HamitoSemitic and Other Language Groups. In: Kaye, A. S. (ed.): Semitic Studies in Honor of Wolf Leslau. Volume I. Wiesbaden, Otto Harrassowitz. Pp. 340-381.

Doornbos, Paul; Bender, Marvin Lionel. 1983. Languages of Wadai-Darfur. In: Bender, Marvin Lionel (ed.): NiloSaharan Language Studies. East Lansing, Michigan, Michigan State University. Pp. 43-79.

DRB = Naït-Zerrad, Kamal. Since 1998. Dictionnaire des racines berbères. Leuven \& Paris, Peeters.

DUL = Olmo Lete, Gregorio del \& Sanmartín, Joaquín. 2003. A Dictionary of the Ugaritic Language in the Alphabetic Tradition. Part One [2(a/i/u)-k]. Part Two [l-z]. Leiden, E.J. Brill.

EA = Knudtzon, J. A. 1915. Die El-Amarna-Tafeln. I-II. Leipzig, J.C. Hinrichs'sche Buchhandlung.

EDE I = Takács, Gábor. 1999. Etymological Dictionary of Egyptian. Volume One: A Phonological Introduction. Leiden, E. J. Brill.

EDE II = Takács, Gábor. 2001. Etymological Dictionary of Egyptian. Volume Two: $b$-, p-, f-. Leiden, E. J. Brill.

Edel, Elmar. 1955., Altägyptische Grammatik. Roma, Pontificium Institutum Biblicum.

Edel, Elmar. 1975. Beiträge zum ägyptischen Lexikon VI. Zeitschrift für Ägyptische Sprache 102, 13-30.

Edel, Elmar. 1975. Zur Deutung des Keilschriftvokabulars EA 368 mit ägyptischen Wörtern. Göttinger Miszellen 15, $11-16$.

Edel, Elmar. 1980. Neue Deutungen keilschriftlicher Umschreibungen ägyptischer Wörter und Personennamen. Sitzungsberichte der Österreichischen Akademie der Wissenschaften, phil.-hist. Klasse 375, 1-48.

Ehret, Christopher. 1980. The Historical Reconstruction of Southern Cushitic Phonology and Vocabulary. Berlin, Dietrich Reimer Verlag.

Ehret, Christopher \& Nuuh Ali, Mohamed. 1984. Soomaali Classification. In: Labahn, Thomas (ed.): Proceedings of the Second International Congress of Somali Studies. Vol. 1. Hamburg, Buske Verlag. Pp. 201-269.

Ehret, Christopher. 1987. Proto-Cushitic Reconstruction. Sprache und Geschichte in Afrika 8.

Ehret, Christopher. 1995. Reconstructing Proto-Afroasiatic (Proto-Afrasian). Vowels, Tone, Consonants, and Vocabulary. Berkeley, Los Angeles, California, University of California.

Ehret, Christopher. 1997. (Additions to the Afroasiatic reconstructions.) MS. Los Angeles, California, 522 p.

Ember, Aaron. 1911. Semito-Egyptian Sound Changes. Zeitschrift für Ägyptische Sprache 49, 87-92.

Ember, Aaron. 1912. Notes on the Relation of Egyptian and Semitic. Zeitschrift für Ägyptische Sprache 50, 86-90.

Ember, Aaron. 1914. Several Semito-Egyptian Particles. Zeitschrift für Assyriologie 28/2-4, 302-306. 
Ember, Aaron. 1917. Kindred Semito-Egyptian Words (New Series). Continued from Vol. 51 pp. $110-121$. Zeitschrift für Ägyptische Sprache 53, 83-90.

Ember, Aaron. 1926. Partial Assimilation in Old Egyptian. In: Adler, Cyrus \& Ember, Aaron (eds.): Oriental Studies Published in Commemoration of the Fortieth Anniversary (1883-1923) of Paul Haupt as the Director of the Oriental Seminary of the Johns Hopkins University. Baltimore, The Johns Hopkins University Press. Pp. 300-312.

Erman, Adolf. 1892. Das Verhältnis des Ägyptischen zu den semitischen Sprachen. Zeitschrift der Deutschen Morgenländischen Gesellschaft 46, 93-129.

ESS = Ember, Aaron. 1930. Egypto-Semitic Studies. Leipzig, The Alexander Cohut Memorial Foundation.

Faber, Alice. 1984. Semitic Sibilants in an Afro-Asiatic Context. Journal of Semitic Studies 29/2, 189-224.

Farina, Giulio. 1924. Le vocali dell'antico egiziano. Aegyptus 5/4, 313-325.

Farina, Giulio. 1926. Grammatica della lingua egiziana antica in caratteri geroglifici. ${ }^{2}$ Milano, U. Hoepli.

FD = Faulkner, Raymond Oliver. 1962. A Concise Dictionary of Middle Egyptian. Oxford, Clarendon Press.

Fédry, Jacques (avec la collaboration de Khamis, Jonas \& o’Nedjei, Moussa). 1971. Dictionnaire dangaleat (Tchad). Thése de $3^{\text {ème }}$ cycle, Institut National des Langues et Civilisations Orientales. Lyon, Afrique et Langage.

Fleming, Harold C. 1976. Omotic Overview. In: Bender, Marvin Lionel (ed.): The Non-Semitic Languages of Ethiopia. East Lansing, Michigan State University. Pp. 299-323.

Fleming, Harold C. 2000. The Eight “Blood” Etymologies in Afrasian (pp. 1-4). The Two Two "Bone" Etymologies in Afrasian (pp. 4-6). Dominant "Four" and a Somewhat Lesser One (pp. 6-7). Stone, Sand, and Sometimes Mountain (pp. 7-9). Tooth and Sometimes Bite E Chew (pp. 9-11). Tongue and Its Actions, especially Lick (pp. 11-14). Bonus Etymology: Lightning or Bright, Shiny or Flash, Ray (pp. 14-16). MS. Presented at the $28^{\text {th }}$ NACAL (Portland, Oregon, 10-12 March 2000). 16 p.

Foucauld, Charles de. 1951-2. Dictionnaire touareg-français, dialecte de l'Ahaggar. Vol. I-IV. Paris, Imprimerie Nationale de France.

Foulkes, H. D. 1915. Angass Manual. Grammar, Vocabulary. London, Kegan Paul, Trench, Trübner and Co.

Gabelentz, G. von der (herausgegeben nach dem hinterlassenen Manuscripte durch Dr. A.C. Graf von der Schulenburg). 1894. Die Verwandtschaft des Baskischen mit den Berbersprachen Nord-Africas nachgewiesen von G.v.d. Gabelentz. Braunschweig, Verlag von Richard Sattler.

Garbini, G. 1972. Le lingue semitiche. Studi di storia linguistica. Napoli, Istituto Orientale di Napoli.

GÄSW = Calice, Franz von. 1936. Grundlagen der ägyptisch-semitischen Wortvergleichung. Wien, Selbstverlag des Orientalischen Institutes der Universität Wien.

$\mathrm{GB}=$ Gesenius, Wilhelm (bearbeitet von Buhl, Frants). 1962. Hebräisches und aramäisches Handwörterbuch über das Alte Testment. Unveränderter Neudruck der 1915 erschienenen 17. Auflage. Berlin, Göttingen, Heidelberg, Springer-Verlag.

GD = Landberg, Le Comte de. 1920-1942. Glossaire dațînois. Vol. I-III. Leiden, E.J. Brill.

Gordon, Cyrus H. 1988. West Semitic Factors in Eblaite. In: Arbeitman, Yoël L. (ed.): Fucus. A Semitic/Afrasian Gathering in Remembrance of Albert Ehrman. Amsterdam, Philadelphia, John Benjamins. Pp. 261-266.

Grande, Bencion Meerovič. 1972. Vvedenie v sravnitel'noe izučenie semitskih jazykov. Moskva, Nauka.

Greenberg, Joseph H. 1947. Arabic Loan-Words in Hausa. Word 3, 85-97.

Greenberg, Joseph H. 1950. The Patterning of Root Morphemes in Semitic. Word 6, 162-181.

Greenberg, Joseph H. 1955. Studies in African linguistic Classification. Branford, Connecticut, Compass Publishing Company.

Greenberg, Joseph H. 1958. The Labial Consonants of Proto-Afro-Asiatic. Word 14, 295-302.

Greenberg, Joseph H. 1962. On the African Affiliation of Hebrew and the Semitic Languages. Jewish Social Studies 24, 79-85.

Greenberg, Joseph H. 1963. The Languages of Africa. International Journal of American Linguistics 29.

Greenberg, Joseph H. 1965. The Evidence for */mb/ as a Proto-Afroasiatic Phoneme. In: Symbolae linguisticae in honorem Georgie Kuryłowicz. Wrocław, Warszawa, Kraków, Widawnictwo Polskiej Akademii Nauk. Pp. 88-92.

Grottanelli, Vinigi L. 1940. Missione etnografica nel Uollega occidentale. Volume primo. Roma, Reale Accademia d'Italia.

Grottanelli, Vinigi L. 1941. Gli Scinascia del Nilo Azzuro ed alcuni lessico poconoti della noro lingua. Rassegna di Studi Etiopici 1/3, 234-270.

Haberland, Eike \& Lamberti, Marcello. 1988. Ibaaddo ka-Ba'iso. Culture and Language of the Ba'iso. Heidelberg, Carl Winter Universitätsverlag. 
Hayward, Richard J. 1982. Notes on the Koyra Language. Afrika und Übersee 65, 211-268.

Hayward, Dick (Richard J.) 1984. The Arbore Language: A First Investigation Including a Vocabulary. Hamburg, Helmut Buske Verlag.

Heine, Bernd. 1973. Vokabulare ostafrikanischer Restsprachen. Teil I. Afrika und Übersee 56, $276-283$.

Heine, Bernd. 1976. Notes on the Rendille Language. Afrika und Übersee 59, 176-223.

Heine, Bernd; Rottland, Franz; Voßen, Rainer. 1979. Proto-Baz: Some Aspects of Early Nilotic-Cushitic Contacts. Sprache und Geschichte in Afrika 1, 75-91.

Heine, Bernd. 1980. The Non-Bantu Languages of Kenya. Berlin, Reimer.

Hodge, Carleton T. 1968. Some Afroasiatic Etymologies. Anthropological Linguistics 10/3, 19-29.

Hodge, Carleton T. 1976. An Egypto-Semitic Comparison. Folia Orientalia 17, 5-28.

Hodge, Carleton T. 1981. Comparative Evidence for Egyptian Historical Phonology. In: Young, D. W. (ed.): Studies Presented to Hans Yakob Polotsky. East Gloucester, Pirtle and Polson. Pp. 401-413.

Hodge, Carleton T. 1990. The Multivalence of Hittite h. In: The Seventeenth LACUS Forum 1990. Lake Bluff, LACUS. Pp. 368-374.

Hodge, Carleton T. 1990. The Role of Egyptian within Afroasiatic. In: Baldi, Ph. (ed.): Linguistic Change and Reconstruction Methodology. Berlin, New York, Mouton de Gruyter. Pp. 639-659.

Hoffmann, Carl. 1970. Ancient Benue-Congo Loans in Chadic? Africana Marburgensia 3/2, 3-23.

Hoffmann, Carl. 1971. On the Classification of Nancere. Journal of West African Languages 8/1, 5-12.

Hoffmann, Carl. 1971. On the Position of Paduko. In: Actes du huitième congrés international de linguistique africaine. Abidjan, 24-28 Mars 1969. Vol. 1. Abidjan, Université d'Abidjan. Pp. 221-233.

Hoffmann, Carl. 1972. Masa and Kim. Zeitschrift der Deutschen Morgenländischen Gesellschaft 122, $180-219$.

Hoffmann, Carl. 1975. Towards a Comparative Phonology of the Languages of the Angas-Goemai Group. MS. University of Ibadan, faculty seminar on 19 March 1975. 32 p.

Holma, Harri. 1919. Zur semitisch-hamitischen Sprachwissenschaft. Zeitschrift für Assyriologie 32, 34-47.

Holmer, Nils M.: The Semantics of Numerals. In: Arsbok 1963-4 (1966), 14-48.

Homburger, Lilas. 1928. Notes sur quelques morphèmes communs à l'égyptien et aux langues négro-africaines. Journal Asiatique 212, 323-345.

Hommel, Fritz. 1883. Die semitischen Völkern und Sprachen. Leipzig, Otto Schulze.

Hommel, Fritz. 1894. Über den Grad der Verwandtschaft des Altägyptischen mit dem Semitischen. Beiträge zur Assyriologie 2, 342-358.

Hommel, Fritz. 1915. Miszellen. In: Weil, G. (ed.): Festschrift Eduard Sachau zum siebzigsten Geburtstage gewidmet von Freunden und Schülern. Berlin, Verlag von Georg Reimer. Pp. 15-21.

HSED = Orel, Vladimir Émmanuilovič \& Stolbova, Ol'ga Valer'evna. 1995. Hamito-Semitic Etymological Dictionary . Leiden, E. J. Brill.

Ibriszimow, Dymitr. 1988. Some Remarks on Chadic Numerals. In: Möhling, J. G. (ed.): Afrikanistische Beiträge zum XXIV. Deutschen Orientalistentag, 26.-30. September 1988. Köln, Institut für Afrikanistik. Afrikanistische Arbeitspapiere, Tagungsband, XXIV. Deutschen Orientalistentag (1988), 64-74.

Ibriszimow, Dymitr. 1990. Towards a Common Chadic Lexicon. Zeszyty Naukowe Universytetu Jagiellońskiego. Prace językoznawcze 102, 1-122.

IL = Institute of Linguistics. 1972. Bauchi Area Survey Report presented by N. Campbell and J. Hoskison. MS. Zaria.

Illič-Svityč, Vladislav Markovič. 1964. Drevnejšie indoevropejsko-semitskie jazykovye kontakty. In: Toporov, Vladimir Nikolayevič (red.): Problemy indoevropejskogo jazykoznanija. Moskva, Nauka. Pp. 3-12.

Illič-Svityč, Vladislav Markovič. 1966. Iz istorii čadskogo konsonantizma. Labial'nye smyčnye. In: Uspenskij, Boris Andreevič (red.): Jazyki Afriki. Voprosy struktury, istorii i tipologii. Moskva, Nauka. Pp. 9-34.

Illič-Svityč, Vladislav Markovič. 1976. Opyt sravnenija nostratičeskih jazykov (semitohamitskij, kartvel'skij, indoevropejskij, ural'skij, dravidijskij, altajskij). Sravnitel'nyj slovar' (l-ź). Ukazateli. Moskva, Nauka.

Johnstone, Thomas Muir. 1977. Harsūsi Lexicon. London, Oxford University Press.

Johnstone, Thomas Muir. 1981. Jibbāli Lexicon. London, Oxford University Press.

Johnstone, Thomas Muir. 1987. Mehri Lexicon. London, University of London.

Jungraithmayr, Herrmann. 1961. Beobachtungen zur tschadohamitischen Sprache der Jegu (und Jonkor) von Abu Telfan (Republique du Tchad). Afrika und Übersee 45, 95-123.

Jungraithmayr, Herrmann. 1965. Materialen zur Kenntnis des Chip, Montol, Gerka und Burrum (Südplateau, Nordnigerien). Afrika und Übersee 48, 161-183. 
Jungraithmayr, Herrmann. 1973. Masa (Bongor) Lexicon. MS. Marburg (now in Frankfurt).

Jungraithmayr, Herrmann. 1977. Kofa Wordlist. MS. 18 p.

Jungraithmayr, Herrmann \& Shimizu, Kiyoshi. 1981. Chadic Lexical Roots. Vol. II. Tentative Reconstruction, Grading and Distribution. Berlin, Verlag von Dietrich Reimer.

Jungraithmayr, Herrmann. 1982. Chadic within Hamitosemitic or between Hamitosemitic and Nigritic? In: Jungraithmayr, Herrmann (ed.): The Chad Languages in the Hamitosemitic-Nigritic Border Area. Berlin, Dietrich Reimer Verlag. Pp. 3-8.

Jungraithmayr, Herrmann. 1990. Lexique mokilko. Berlin, Dietrich Reimer Verlag.

Jungraithmayr, Herrmann. 1990. Lexique mubi-français (Tchad oriental). MS. Frankfurt a/M, 50 p.

Jungraithmayr, Herrmann \& Ibriszimow, Dymitr. 1994. Chadic Lexical Roots. Volume I. Tenative Reconstruction, Grading, Distribution and Comments. Berlin, Dietrich Reimer Verlag.

Jungraithmayr, Herrmann \& Ibriszimow, Dymitr. 1994. Chadic Lexical Roots. Volume II. Documentation. Berlin, Dietrich Reimer Verlag.

Jungraithmayr, Herrmann. 2004. Das Birgit, eine osttschadische Sprache - Vokabular und grammatische Notizen. In: Takács, Gábor (ed.): Egyptian and Semito-Hamitic (Afro-Asiatic) Studies in Memoriam Werner Vycichl. Leiden, E. J. Brill. Pp. 342-371.

Kammerzell, Frank. 1994. Panther, Löwe und Sprachentwicklung im Neolithikum. Bemerkungen zur Etymologie des ägyptischen Theonyms M?fd.t, zur Bildung einiger Raubtiernamen im Ägyptischen und zu einzelnen Grosskatzenbezeichnungen indoeuropäischer Sprachen. Göttingen, Seminar für Ägyptologie und Koptologie.

Kammerzell, Frank. 1994. Zur Etymologie des ägyptischen Zahlworts “4”. Lingua Aegyptia 4, 165-189.

Kane, Thomas Leiper. 1990. Amharic-English Dictionary. Wiesbaden, Harrassowitz Verlag.

KB = Koehler, Ludwig \& Baumgartner, Walter. 1994-2000. The Hebrew and Aramaic Lexicon of the Old Testament. Vol. I-V. Leiden, E. J. Brill.

KHW = Westendorf, Wolfhart. 1977. Koptisches Handwörterbuch. Heidelberg, Carl Winter Universitätsverlag.

Kießling, Roland \& Mous, Maarten. 2004. The Lexical Reconstruction of West-Rift Southern Cushitic. Kuschitische Sprachstudien, Band 21. Köln, Rüdiger Köppe Verlag.

Klein, Ernest. 1987. A Comprehensive Eymological Dictionary of the Hebrew Language for Readers of English. New York, Macmillan.

Korostovcev, Mihail Aleksandrovič. 1963. Vvedenie v egipetskuju filologiju. Moskva, Izdatel'stvo Vostočnoj Literatury.

Kossmann, Maarten. 1999. Essai sur la phonologie du proto-berbère. Köln, Köppe.

Kraft, Charles H. 1972. Gude-Dialekte. MS.

Kraft, Charles H. 1981. Chadic Wordlists. Vol. I-III. Berlin, Dietrich Reimer Verlag.

Lacau, Pierre. 1970. Les noms des parties du corps en égyptien et en sémitique. Paris, Librairie C. Klincksieck.

Lacau, Pierre. 1970. Études d’Égyptologie. I. Phonétique égyptienne ancienne. Le Caire, IFAO.

Lambdin, Thomas Oden. 1958. The Bivalence of Coptic eta and Related Problems in the Vocalization of Egyptian. Journal of Near Eastern Studies 17, 177-193.

Lamberti, Marcello. 1993. Die Shinassha-Sprache. Materialien zum Boro. Heidelberg, Carl Winter Universitätsverlag.

Lamberti, Marcello. 1993. Materialien zum Yemsa. Heidelberg, Carl Winter Universitätsverlag.

Lamberti, Marcello. 1993. The Ari-Banna Group and Its Classification. Studi Italiani di Linguistica Teorica e Applicata 22/1, 39-87.

Lamberti, Marcello. 1993. Some Phonetic Laws of the Gonga Languages. Second Part. Rassegna di Studi Etiopici 37 (1993), 89-114.

Lamberti, Marcello \& Sottile, Roberto. 1997. The Wolaytta Language. Köln, Rüdiger Köppe Verlag.

Lane, Edward William. 1863-1893. An Arabic-English Lexicon. Vol. I-VIII. London, Edinburgh, Williams and Norgate.

Lanfry, Jacques. 1973. Ghadames. II. Glossaire. Alger, Le Fichier Periodique.

Lang, Karl. 1923-4. Die Etymologie des Wortes "Pyramide”. Anthropos 18-19, 551-553.

Laoust, Émile. 1931. Siwa. I. Son parlier. Paris, Librairie Ernest Leroux.

LÄ = Helck, Wolfgang \& Westendorf, Wolfhart (Hrsg., begründet von Wolfgang Helck und Eberhard Otto). 19751992. Lexikon der Ägyptologie. Band I-VII. Wiesbaden, Harrassowitz.

Lefébvre, Gustave. 1955. Grammaire de l'égyptien classique.² Le Caire, Institut Français d'Archéologie Orientale, Le Caire. 
Leslau, Wolf. 1931-4. Explications et rapprochements à propos de quelques éléments du vocabulaire mehri. In: Comptes-Rendues du Groupe Linguistique d'Études Chamito-Sémitiques 1, 35-38.

Leslau, Wolf. 1938. Lexique soqoțri (sudarabique moderne), avec comparaisons et explications étymologiques. Paris, Librairie C. Klincksieck.

Leslau, Wolf. 1945. Gafat Documents. Records of a South-Ethiopic Language. Grammar, Text and Comparative Vocabulary. New Haven, Connecticut, American Oriental Society.

Leslau, Wolf. 1959. A Dictionary of Moča (Southwestern Ethiopia). Berkeley, Los Angeles, University of California Press. Leslau, Wolf. 1962. Semitic and Egyptian Comparisons. Journal of Near Eastern Studies 21, 44-49.

Leslau, Wolf. 1963. Etymological Dictionary of Harari. Berkeley, Los Angeles, University of California.

Leslau, Wolf. 1979. Etymological Dictionary of Gurage (Ethiopic). Vol. III. Etymological Section. Wiesbaden, Otto Harrassowitz.

Leslau, Wolf. 1987. Comparative Dictionary of Ge\{ez (Classical Ethiopic). Wiesbaden, Otto Harrassowitz.

Lexa, František. 1922. Comment se revèlent les rapports entre les langues hamitiques, sémitiques et la langue égyptienne dans la grammaire des pronoms personnels, des verbes et dans les numéraux cardinaux 1-9. Philologica 1, 151-177.

Lexa, František. 1938. Développement de la langue ancienne égyptienne. Archív Orientální 10, $215-272$.

Lipiński, Edward. 1997. Semitic Languages. Outline of a Comparative Grammar. Leuven, Uitgeverij Peeters en Departement Oosterse Studies.

Loprieno, Antonio. 1986. Zahlwort. In: Lexikon der Ägyptologie VI, 1306-1319.

Loprieno, Antonio. 1994. Zu einigen Phänomenen ägyptischer Phonologie. In: Behlmer, Heike (Hrsg.): Quaerentes Scientiam. Festgabe für Wolfhart Westendorf zu seinem 70. Geburtstag überreicht von seinen Schülern. Göttingen, Hubert \& Co. Pp. 119-131.

Loprieno, Antonio. 1995. Ancient Egyptian. A Linguistic Introduction. Cambridge, Cambridge University Press.

Lukas, Johannes. 1937. Zentralsudanische Studien. In: Abhandlungen aus dem Gebiet der Auslandskunde, Hansische Universität, Reihe B, Band 45/24.

Lukas, Johannes. 1941. Deutsche Quellen zur Sprache der Musgu in Kamerun. Berlin, Dietrich Reimer Verlag.

Lukas, Johannes. 1966. Tschadohamitische Sprachproben aus Nordnigerien (Karekare- und Bolanci-Texte). In: Lukas, Johannes (Hrsg.): Neue afrikanistische Studien. Hamburg, Deutsches Institut für Afrika-Forschung. Pp. 173-207.

Lukas, Johannes. 1977. Tschadische Studien I. Beiträge zur Kenntnis des Mokulu. Afrika und Übersee 60, 1-58, 182229.

MacDonald, John. 1963-5. New Thoughts on the Biliteral Origin for the Semitic Verb. The Annual of Leeds University Oriental Society 5, 63-85.

Matsushita, Shuji. 1972. An Outline of Gwandara Phonemics and Gwandara-English Vocabulary. Tokyo, Tokyo Press.

Meinhof, Carl. 1906. Linguistische Studien in Ostafrika. Fortsetzung. Mitteilungen des Seminars für Orientalische Sprachen 9, 278-333.

Meinhof, Carl. 1907. Linguistische Studien in Ostafrika. Fortsetzung. Mitteilungen des Seminars für Orientalische Sprachen 10, 90-123.

Meinhof, Carl. 1912. Die Sprachen den Hamiten. Hamburg, Friedrichsen \& Co.

Mercier, Gustave. 1933. La numération libyenne. Journal Asiatique 222, 303-322.

Meyer-Bahlburg, Hilke. 1972 (?). Deutsch-Musgu: Nomina (Girvidig aufgenommen von J. Lukas in 1957-58, Pus aus dem Neuen Testament). MS. 11 p.

Meyer-Bahlburg, Hilke. 1972-3. Texte im Musgu von Girvidik (Nordkamerun). Afrika und Übersee 56, 61-71.

Militarev, Aleksandr Jur'evič \& Stolbova, Ol'ga Valer'evna. 1990. First Approach to Comparative-Historical Phonology of Afrasian (Consonantism). In: Mukarovsky, Hans G. (ed.): Proceedings of the Fifth International Hamito-Semitic Congress. Band I. Wien, Afro-Pub. Pp. 45-72.

Militarev, Aleksandr Jur'evič. 1991., Neskol'ko peredneaziatskih étimologij. In: Šarbatov, Grigorij Šamilevič (red.): Irano-afrazijskie jazykovye kontakty. Vypusk 2. Moskva, Nauka. Pp. 72-77.

Militarev, Aleksandr Jur'evič. 1991. Guančskie jazyki. Fonetika. In: Solncev, Vadim Mihajlovič (red.): Jazyki Azii $i$ Afriki. IV, kniga 2. Moskva, Glavnaja Redakcija Vostočnoj Literatury. Pp. 163-173.

Militarev, Aleksandr Jur'evič. 1991. Istoričeskaja fonetika i leksika livijsko-guančskih jazykov. In: Solncev, Vadim Mihajlovič (red.): Jazyki Azii i Afriki. IV, kniga 2. Moskva, Glavnaja Redakcija Vostočnoj Literatury. Pp. 238267. 
Moreno, Martino Mario. 1938. Introduzione alla lingua ometo. Milano, Mondadori.

Moscati, Sabatino; Spitaler, Anton; Ullendorf, Edward; Soden, Wolfram von. 1964. An Introduction to the Comparative Grammar of the Semitic Languages. Phonology and Morphology. ${ }^{2}$ Wiesbaden, Otto Harrassowitz.

Mouchet, Jean. 1950. Vocabulaires comparatifs de quinze parlers du Nord-Cameroun. Bulletin de la Société d'Études Camerounaises 29-30, 5-74.

Mouchet, Jean. 1966. Le parler daba: esquisse grammaticale précédée d'une note sur l'ethnie daba, suivie de lexiques dabafrançais et français-daba. Yaoundé, R.E.C.

Mukarovsky, Hans G. 1987. Mande-Chadic Common Stock. A Study of Phonological and Lexical Evidence. Wien, Afro-Pub.

Müller, W. Max. 1907. Ägyptische und semitische Umschreibungsfragen. Orientalistische Literaturzeitung 10, 299305, 358-360.

Müller, W. Max. 1909. The False $\mathrm{r}$ in Archaic Egyptian Orthography. Recueil de Travaux Relatifs à la Philologie et à l'Archéologie Égyptiennes et Assyriennes 31 (NS 15), 182-201.

NBÄ = Osing, Jürgen. 1976. Die Nominalbildung des Ägyptischen. Band I-II. Maiz/Rhein, Verlag Philipp von Zabern.

Nehlil, Mohamed. 1909. Étude sur le dialecte de Ghat. Paris, Éditions Ernest Leroux.

Newman, Paul. 1964. A Word List of Tera. Journal of West African Languages 1/2, 33-50.

Newman, Paul \& Ma, Roxana. 1966. Comparative Chadic: Phonology and Lexicon. Journal of African Languages 5/3, 218-251.

Newman, Paul. 1977. Chadic Classification and Reconstructions. Afroasiatic Linguistics 5/1, 1-42.

Nicolas, Francis J. 1953. La langue berbère de Mauritanie. Dakar, Institut Français d'Afrique Noire.

Oomen, Antoinette. 1981. Gender and Plurality in Rendille. Afroasiatic Linguistics 8/1, 35-75.

Orel, Vladimir Émmanuilovič \& Stolbova, Ol'ga Vladimirovna. 1988. K rekonstrukcii praafrazijskogo vokalizma. 1-2. Voprosy Jazykoznanija 5, 66-83.

Orel, Vladimir Émmanuilovič \& Stolbova, Ol'ga Vladimirovna. 1992. On Chadic-Egyptian Lexical Relations. In: Shevoroshkin, V. (ed.): Nostratic, Dene-Caucasian, Austric and Amerind. Bochum, Brockmeyer. Pp. 181-203.

Parker, Enid M. \& Hayward, Richard J. 1985. An Afar-English-French Dictionary (with Grammatical Notes in English). London, School of Oriental and African Studies, University of London.

Pillinger, Steve \& Galboran, Letiwa. 1999. A Rendille Dictionary. Köln, Rüdiger Köppe Verlag.

Pilszczikowa, Nina. 1958. Contribution à l'étude des rapports entre le haoussa et les autres langues du groupe nigéro-tchadien. Rocznik Orientalistyczny 22/2, 75-99.

Plazikowsky-Brauner, Herma. 1950. Schizzo morfologico dello shinasha. Rassegna di Studi Etiopici 9, 65-83.

Plazikowsky-Brauner, Herma. 1963. Zahlen und Zahlensysteme in den sogenannten kuschitischen Sprachen. Mitteilungen des Instituts für Orientforschung 8/3, 466-483.

Prasse, Karl-G. 1969. A propos de l'origine de h touareg (tahaggart). Det Kongelige Danske Videnskabernes Selskab. Historisk-filosofiske Meddelelser 43/3.

Prasse, Karl-G. 1972. Manuel de grammaire touaregue. I-III. Phonétique - écriture - pronom. Copenhague, Université de Copenhague.

Prasse, Karl-G. 1974. Manuel de grammaire touaregue. IV-V. Nom. Copenhague, Akademisk Forlag.

Prasse, Karl-G.; Alojaly, Ghoubeïd; Mohamed, Ghabdouane. 1998. Lexique touareg-français. Copenhague, Museum Tusculanum Press, Université de Copenhague.

Prasse, Karl-G.; Alojaly, Ghoubeïd; Mohamed, Ghabdouane. 2003. Dictionnaire touareg-français (Niger). Copenhagen, Museum Tusculanum Press, University of Copenhagen.

PT = Sethe, Kurth. 1908-1910. Die altägyptischen Pyramidentexte. Band I-II. Leipzig, J.C. Hinrichs'sche Buchhandlung.

Reinisch, Leo. 1874. Die Barea-Sprache. Wien, Wilhelm Braumüller.

Reinisch, Leo. 1886. Die SAfar-Sprache. II. Sitzungsberichte der Kaiserlichen Akademie der Wissenschaften, Phil.-hist. Classe 113/2, 795-916.

Reinisch, Leo. 1888. Die Kafa-Sprache in Nordost-Afrika. II. Kafa-Deutsches Wörterbuch. Sitzungsberichte der Kaiserlichen Akademie der Wissenschaften. Phil.-hist. Classe 116, 251-386.

Reinisch, Leo. 1890. Wörterbuch der Saho-Sprache. Wien, Alfred Hölder.

Reinisch, Leo. 1890 Das Zalwort vier und neun in den chamitisch-semitischen Sprachen. Sitzungsberichte der Kaiserlichen Akademie der Wissenschaften. Phil.-hist. Classe 121/12.

Reinisch, Leo. 1894. Die Beḍawye-Sprache in Nordost-Afrika. III. Sitzungsberichte der Kaiserlichen Akademie der Wissenschaften. Phil.-hist. Classe 130/7, 1-80.

Reinisch, Leo. 1895., Wörterbuch der Bedawye-Sprache. Wien, Alfred Hölder Verlag. 
Renisio, Amédée. 1932. Étude sur les dialectes berbères des Beni Iznassen, du Rif et des Senhaja de Sraïr. Grammaire, textes et lexique. Paris, Éditions Ernest Leroux.

Roper, E.-M. 1928. Tu Bedawie. An Elementary Handbook for the Use of Sudan Government Officials. Hertford, Stephen Austin \& Sons.

Rossing, Melvin Olaf. 1978. Mafa-Mada: A Comparative Study of Chadic Languages in North Cameroun. Ph.D. dissertation. Wisconsin, University of Wisconsin-Madison.

Rössler, Otto. 1952. Der semitische Charakter der libyschen Sprache. Zeitschrift für Assyriologie 50, 121-150.

Rössler, Otto. 1966. Das ältere ägyptische Umschreibungssystem für Fremdnamen und seine sprachwissenschaftliche Lernen. In: Lukas, J. (ed.): Neue afrikanistische Studien. Hamburg, Deutsches Institut für AfrikaForschung. Pp. 218-229.

Rössler, Otto. 1971. Das Ägyptische als semitische Sprache. In: Altheim, F. \& Stiehl, R. (Hrsg.): Christentum am Roten Meer. Band I. Berlin, New York, Walter de Gruyter. Pp. 263-325.

Rundgren, Frithiof. 1961. Semitische Wortstudien. Orientalia Suecana 10, 99-136.

Sachnine, Michka. 1982. Dictionnaire lamé-français. Lexique français-lamé. Paris, SELAF.

Sasse, Hans-Jürgen. 1975. Galla /š/, /s/ und /f/. Afrika und Übersee 58, 244-263.

Sasse, Hans-Jürgen. 1976. Weiteres zu den ostkuschitischen Sibilanten. Afrika und Übersee 59, $125-142$.

Sasse, Hans-Jürgen. 1979. The Consonant Phonemes of Proto-East-Cushitic (PEC). Afroasiatic Linguistics 7/1, 1-67.

Sasse, Hans-Jürgen. 1982. An Etymological Dictionary of Burji. Hamburg, Helmut Buske Verlag.

Schenkel, Wolfgang. 1990. Einführung in die altägyptische Sprachwissenschaft. Orientalistische Einführungen in Gegenstand, Ergebnisse und Perspektiven der Einzelgebiete. Darmstadt, Wissenschaftliche Buchgesellschaft.

Schenkel, Wolfgang. 1991. Tübinger Einführung in die klassisch-ägyptische Sprache und Schrift. Tübingen, Universität Tübingen.

Schenkel, Wolfgang. 1993. Zu den Verschluss- und Reibelauten im Ägyptischen und (Hamito)Semitischen. Ein Versuch zur Synthese der Lehrmeinungen. Lingua Aegyptia 3, 137-149.

Schenkel, Wolfgang. 1997. Tübinger Einführung in die klassisch-ägyptische Sprache und Schrift. Tübingen, Universität Tübingen.

Schlee, Günther. 1978. Sprachliche Studien zum Rendille: Grammatik, Texte, Glossar. Hamburg, Helmut Buske Verlag.

Schuh, Russell G. 1981. A Dictionary of Ngizim. Berkeley, California, University of California.

Schuh, Russell G. 1982. The Hausa Language and Its Nearest Relatives. Harsunan Nijeriya 12, 1-24.

Schuh, Russell G. 1984. West Chadic Vowel Correspondences. In: Bynon, J. (ed.): Current Progress in Afro-Asiatic Linguistics. Amsterdam, John Benjamins. Pp. 167-223.

SD = Beeston, Alfred Felix Landon; Ghul, Mahmud Ali; Müller, Walter W.; Ryckmans, Jacques. 1982. Sabaic Dictionary (English-French-Arabic). Dictionnaire sabéen (anglais-français-arabe). Louvain-la-Neuve, Beyrouth, Peeters, Librairie du Liban.

SED I = Kogan, Leonid \& Militarev, Alexander (with assistance of Anna Belova, Anatoly Kovalev, Adel Nemirovskaja, Denid Nosnitsyn). 2000. Semitic Etymological Dictionary. Vol. I. Anatomy of Man and Animals. Münster, Ugarit-Verlag.

Sethe, Kurt. 1911. Das Wort für König von Oberägypten. Zeitschrift für Ägyptische Sprache und Altertumskunde 49, 15-34.

Sethe, Kurt. 1912. Das Wort für "Hand” im Ägyptischen und der Laut d. Zeitschrift für Ägyptische Sprache und Altertumskunde 50, 91-99.

Sethe, Kurt. 1916. Von Zahlen und Zahlworten bei den alten Ägyptern und was für andere Völker und Sprachen daraus zu lernen ist. Strassburg, Karl J. Trübner.

Sethe, Kurt. 1927. Das Zahlwort “fünf”. Zeitschrift für Ägyptische Sprache und Altertumskunde 62, 60-61.

Shimizu, Kiyoshi. 1978. The Southern Bauchi Group of Chadic Languages. A Survey Report. Africana Marburgensia. Special Issue 2, 1-50.

Siebert, Ralph. 1994. Languages of the Abbaya/Chamo Area - Report Part I (with Notes on Koorete by L. Hoeft). Survey of Little-Known Languages of Ethiopia (S.L.L.E.) Reports 21, 1-24.

Siebert, Ralph \& Wedekind, Claus. 1994. Third S.L.L.E. Survey on Languages of the Begi/Asosa Area. Survey of Little-Known Languages of Ethiopia (S.L.L.E.) Reports 15, 1-19.

Skinner, Neil. 1977. North Bauchi Chadic Languages: Common Roots. Afroasiatic Linguistics 4/1, 1-49.

Skinner, Neil. 1980. Loans in Hausa and Pre-Hausa: Some Etymologies. In: Jungraithmayr, Herrmann (ed.): Berliner afrikanistische Vorträge. XXI. Deutscher Orientalistentag, Berlin, Berlin, 1981., Dietrich Reimer Verlag, 169-202. 
Smith, Sidney; Gadd, Cyril John. 1925. A Cuneiform Vocabulary of Egyptian Words. Journal of Egyptian Archaeology 11, 230-240.

Starostin, Sergej Anatol'evič; Dybo, Vladimir Antonovič; Dybo, Anna Vladimirovna; Helimsky, Evgenij Anatol'evič; Militarev, Aleksandr Jur'evič; Mudrak, Oleg Alekseevič; Starostin, Georgij Sergeevič. 1995. Basic Nostratic-Afrasian-Sino-Caucasian Lexical Correspondences. Preliminary working version. MS. Moscow.

Stolbova, Ol'ga Valer'evna. 1972. Soglasnye verhnezapadnočadskih jazykov. Genetičeskie sootvetstvija. In: Makaev, Énver Ahmedovič (red.): Istoriko-tipologičeskie i sinhronno-tipologičeskie issledovanija (na materiale jazykov raznyh sistem). Moskva, Institut Jazykoznanija Akademii Nauk SSSR.

Stolbova, Ol'ga Valer'evna. 1977. Materialy k sravnitel'noj fonetike afrazijskih jazykov (zapadnočadskie rekonstrukcii). In: Ivanov, Vjačeslav Vsevolodovič; Bulatova, Rimma Vladimirovna; Dybo, Vladimir Antonovič; Helimskij, Evgenij Arnol'dovič (red.): Konferencija “Nostratičeskie jazyki i nostratičeskoe jazykoznanie”. Tezisy dokladov. Moskva, Institut Slavjanovedenija i Balkanistiki Akademii Nauk SSSR. Pp. 64-65.

Stolbova, Ol'ga Valer'evna. 1977. Opyt rekonstrukcii verhnezapadnočadskih kornej. In: Jazyki zarubežnogo Vostoka. Sbornik statej. Moskva, Nauka. Pp. 152-160.

Stolbova, Ol'ga Valer'evna. 1987. Sravnitel'no-istoričeskaja fonetika i slovar' zapadnočadskih jazykov. In: Porhomovskij, Viktor Jakovlevič (red.): Afrikanskoe istoričeskoe jazykoznanie. Problemy rekonstrukcii. Moskva, Nauka. Pp. 30-268.

Stolbova, Ol'ga Valer'evna. 1996. Studies in Chadic Comparative Phonology. Moscow, "Diaphragma” Publishers.

Strümpell, Kurt (und Struck, Bernhard). 1910. Vergleichendes Wörterverzeichnis der Heidensprachen Adamauas. Zeitschrift für Ethnologie 42, 444-488.

Strümpell, Kurt. 1922-3. Wörterverzeichnis der Heidensprachen des Mandara-Gebirges (Adamaua). Zeitschrift für Eingeborenen-Sprachen 13, 109-149.

Takács, Gábor. 1994. Some Notes on the History of Egyptian m̌̌ “Ten”. Folia Orientalia 30, 217-218.

Takács, Gábor. 1995. Afrasian Numerals in Egyptian and Egyptian Numerals in Afrasian. MS. Székesfehérvár.

Takács, Gábor. 1996. Egyptian Lexics in an Afrasian Perspective: New Etymologies. Studia Etymologica Cracoviensia 1, 125-171.

Takács, Gábor. 1996. Towards the Etymology of Egyptian md “Ten”. Acta Orientalia Acadaemiae Scientiarum Hungariae 49/3, 441-448.

Takács, Gábor. 1997. Afrasian Numerals in Egyptian and Egyptian Numerals in Afrasian. Lingua Aegyptia 5, 211222.

Takács, Gábor. 1999. Development of Afro-Asiatic (Semito-Hamitic) Comparative-Historical Linguistics in Russia and the Former Soviet Union. München, Newcastle, Lincom Europa.

Takács, Gábor. 1999. Review of Solncev, Vadim Mihajlovič (red.): Jazyki Azii i Afriki IV/2 - A New Contribution to Berber Comparative-Historical Linguistics by Aleksandr Jur'evič Militarev: Some Etymological Notes. Lingua Posnaniensis 41, 198-209.

Takács, Gábor. 2000. The Origin of Ahaggar h in an Afro-Asiatic Perspective. In: Chaker, Salem \& Zaborski, Andrzej (éds.): Études berbères et chamito-sémitiques. Mélanges offerts à Karl-G. Prasse pour son $70^{e}$ anniversaire. Paris, Louvain, Éditions Peeters. Pp. 333-356.

Takács, Gábor. 2004. Comparative Dictionary of the Angas-Sura Languages. Berlin, Dietrich Reimer Verlag.

Takács, Gábor. 2006. Tamazight Lexicon and Its Afro-Asiatic Background: The Evidence of Root-Initial ḍ- and z-. In: Allati, Abdelaziz et al. (éds.): Linguistique amazighe: les nouveaux horizons. Actes du Colloque international: 17, 18, 19 février 2005. Tétouan, Publications de la Faculté des Lettres et des Sciences Humaines de Tétouan, Université Abdelmalek Essaâdi. Pp. 48-63.

Takács, Gábor. 2015. Archaeologia Afroasiatica I: Disintegration of the Parental Language. Mother Tongue 20, forthc.

Toselli, P./Fr. Giovanni (a cura del P. Giovanni Chiomio). 1939. Elementi di lingua magi. Grammatica e dizionario con alcuni cenni sulla popolazione magi. Torino, Istituto Missioni Consolata.

Tourneux, Henry; Seignobos, Christian; Lafarge, Francine. 1986. Les Mbara et leur langue (Tchad). Paris, Société d'Études Linguistiques et Anthropologiques de France.

Tourneux, Henry. 1991. Lexique pratique du munjuk des rizières. Dialecte de Pouss. Paris, Librairie Orientaliste Paul Geuthner.

Da Trento, Gabriele. 1941. Vocaboli in lingue dell'Etiopia meridionale. Rassegna di Studi Etiopici 1, $203-297$.

Trombetti, Alfredo. 1902. Delle relazioni delle lingue caucasiche con le lingue camitosemitiche e con altri gruppi linguistici. Giornale della Società Asiatica Italiana 15, 177-201. 
Trombetti, Alfredo. 1977. Elementi di glottologia. ${ }^{2}$ Bologna, Arnoldo Forni Editore.

ÜKAPT I-VI = Sethe, Kurt. 1935-1962. Übersetzung und Kommentar zu den altägyptischen Pyramidentexten. Band I-VI. Glückstadt, Hamburg, J. J. Augustin.

Venberg, Rodney. 1975. Phonemic Statement of the Peve Language. Africana Marburgensia 8/1, 26-43.

Vergari, Moreno \& Vergari, Roberta. 2003. A Basic Saho-English-Italian Dictionary. Asmara, Eritrea, (publisher not indicated).

Vergote, Josef. 1945. Phonétique historique de l'égyptien. Paris, Le Muséon.

Vernus, Pascal. 2000. Situation de l'égyptien dans les langues du monde. In: Fauvelle-Aymar, François-Xavier; Chrétien, Jean-Pierre; Perrot, C.-H. (éds.): Afrocentrismes. L’histoire des Africains entre Égypte et Amérique. Paris, Éditions Karthala. Pp. 169-208.

Voigt, Rainer Maria. 1994. Die Entsprechung der ursemitischen Interdentale im Altäthiopischen. In: Heinrichs, Wolfhart \& Schoeler, Gregor (eds.): Festschrift Ewald Wagner zum 65. Geburtstag. Band 1. Semitische Studien unter besonderer Berücksichtigung der Südsemitistik. Beirut, im Komission bei Franz Steiner Verlag Stuttgart. Pp. 102-117.

Vycichl, Werner. 1934. Hausa und Ägyptisch. Ein Beitrag zur historischen Hamitistik. Mitteilungen des Seminars für Orientalische Sprachen an der Friedrich-Wilhelms-Universität zu Berlin 37, 36-116.

Vycichl, Werner. 1938. Festgabe für Hermann Junker zu seinem 60. Geburtstag. Archiv für Aegyptische Archaeologie $1 / 6,131-140$.

Vycichl, Werner. 1953. Die ägyptischen Ausdrücke für "Selbst". Muséon 66, 41-44.

Vycichl, Werner. 1955. Der Umlaut in den Berbersprachen Nordafrikas. Eine Einführung in die berberische Sprachgeschichte. Wiener Zeitschrift für die Kunde des Morgenlandes 52, 304-325.

Vycichl, Werner. 1957. PiSelformen im Ägyptischen und im Koptischen. Die Etymologie von koptisch cooun "wissen”. Mitteilungen des Instituts für Orientforschung 5, 10-25.

Vycichl, Werner. 1958. Grundlagen der ägyptisch-semitischen Wortvergleichung. Mitteilungen des Deutschen Archäologischen Instituts, Abteilung Kairo 16, 367-405.

Vycichl, Werner. 1959. Is Egyptian a Semitic Language? Kush 7, 27-44.

Vycichl, Werner. 1960. The Beja Language Tū Bedawīye. Its Relationship with Old Egyptian. Kush 8, 252-264.

Vycichl, Werner. 1966. Sprachliche Beziehungen zwischen Ägypten und Afrika. In: Lukas, Johannes (Hrsg.): Neue afrikanistische Studien. Hamburg, Deutsches Institut für Afrika-Forschung. Pp. 265-272.

Vycichl, Werner. 1974. Les études chamito-sémitiques à l'Université de Fribourg et le "Lamekhitique". In: Caquot, André \& Cohen, David (eds.): Actes du premier congrès international de linguistique sémitique et chamitosémitique, Paris 16-19 juillet 1969. Paris, Mouton. Pp. 60-67.

Vycichl, Werner. 1978. L'état actuel des études chamito-sémitiques. In: Fronzaroli, Pelio (ed.): Atti del Secondo Congresso Internazionale di Linguistica Camito-Semitica, Firenze, 16-19 aprile 1974. Firenze, Istituto di Linguistica e di Lingue Orientali, Università di Firenze. Pp. 63-76.

Vycichl, Werner. 1987. The Origin of the Hamito-Semitic Languages. In: Jungraithmayr, Herrmann \& Müller, Walter W. (eds.): Proceedings of the Fourth International Hamito-Semitic Congress, Marburg, 20-22 September 1983. Amsterdam, Philadelphia, John Benjamins. Pp. 109-121.

Vycichl, Werner. 1992. Die pharyngalen Laute Sayin und -ā im Berberischen. In: Ebermann, Erwin; Sommerauer, E. R.; Thomanek, K. É. (Hrsg.): Komparative Afrikanistik: Sprach-, geschichts- und literaturwissenschaftliche Aufsätze zu Ehren von Hans G. Mukarovsky. Wien, Afro-Pub. Pp. 383-386.

Ward, William A. 1985. Reflections on Methodology in Egypto-Semitic Lexicography. In: Tubb, Jonathan N. (ed.): Palestine and the Bronze and Iron Ages. Papers in Honour of Olga Tufnell. London, Institute of Archaeology. Pp. 232-248.

$\mathrm{Wb}=$ Erman, Adolf \& Grapow, Hermann. 1957-1971. Wörterbuch der ägyptischen Sprache. Band I-V.² Berlin, Akademie-Verlag.

Wente-Lukas, Renate. 1973. Zur sprachlichen Stellung des Bana (Mándara-Gebirge, Nordwestkamerun). Afrika und Übersee 57, 1-15.

Westendorf, Wolfhart. 1962. Grammatik der medizinischen Texte. Berlin, Akademie-Verlag.

Whiteley, Wilfred H. 1953. Studies in Iraqw. Kampala, East African Institute of Social Research.

Wolff, Ekkehard. 1974. Neue linguistische Forschungen in Nordostnigeria. Afrika und Übersee 58/1, 7-27.

Worrell, W. H. 1926. The Hamitic Background of Semitism. Papers of the Michigan Academy of Science. Arts and Letters 7, 269-272. 
Wölfel, Dominik Josef. 1954. Les noms de nombre dans le parler guanche des Iles Canaries. Hespéris 41, 47-79.

Wölfel, Dominik Josef. 1965. Monumenta linguae Canariae. Die kanarischen Sprachdenkmäler. Eine Studie zur Vor- und Frühgeschichte Weißafrikas. Graz, Akademische Druck- u. Verlagsanstalt.

WUS = Aistleitner, Josef. 1963. Wörterbuch der ugaritischen Sprache. Berichte über die Verhandlungen der Sächsischen Akademie der Wissenschaften zu Leipzig, phil.-hist. Klasse 106/3.

Yeivin, Shmuel. 1932. Haqīrōt hašwaZa bəbalšanūt šemīt-mișrīt. 1. Ləšōnenū 2, 136-153.

Zaborski, Andrzej. 1971. Biconsonantal Verbal Roots in Semitic. Zeszyty Naukowe Universytetu Jagiellońskiego, prace jezzkoznawcze 5, 51-98.

Zaborski, Andrzej. 1983. Basic Numerals in the Omotic Languages. In: Segert, Stanislav \& Bodrogligeti, Andras J. E. (eds.): Ethiopian Studies dedicated to Wolf Leslau on the Occasion of His Seventy-Fifth Birthday November 14th, 1981 by His Friends and Colleagues. Wiesbaden, Otto Harrassowitz. Pp. 375-392.

Zaborski, Andrzej. 1987. Basic Numerals in Cushitic. In: Jungraithmayr, Herrmann; Müller, Walter W. (eds.): Proceedings of the Fourth International Hamito-Semitic Congress, Marburg, 20-22 September, 1983. Amsterdam, Philadelphia, John Benjamins. Pp. 317-347.

Zaborski, Andrzej. 1989. Der Wortschatz der Bedscha-Sprache. Eine vergleichende Analyse. In: Schuler, E. von (Hrsg.): XXIII. Deutscher Orientalistentag, vom 16. bis 20. September 1985 in Würzburg. Ausgewählte Vorträge. Stuttgart, Franz Steiner Verlag. Pp. 573-591.

Zavadovskij, Jurij Nikolaevič. 1967. Berberskij jazyk. Moskva, Nauka.

Zavadovskij, Jurij Nikolaevič. 1974. Les noms de nombre berbères a la lumiere des études comparées chamitosemitiques. In: Caquot, André \& Cohen, David (eds.): Actes du premier congrès international de linguistique sémitique et chamito-sémitique. Paris, Mouton. Pp. 102-112.

Zavadovskij, Jurij Nikolaevič. 1975. Problema berberskih čislitel'nyh v svete sravnitel'nogo semito-hamitskogo jazykoznanija. In: Drevnij Vostok. Sbornik 1. K semidesjatiletiju akademika M. A. Korostovceva. Moskva, Nauka. Pp. 42-51.

Zeidler, Jürgen. 1992. Altägyptisch und Hamitosemitisch. Bemerkungen zu den Vergleichenden Studien von Karel Petráček. Lingua Aegyptia 2, 189-222.

Zima, Petr. 1990. Songhay and Chadic in the West African Context. In: Mukarovsky, Hans G. (ed.): Proceedings of the Fifth International Hamito-Semitic Congress. Band 1. Wien, Afro-Pub. Pp. 261-274.

Zyhlarz, Ernst. 1931. Die ägyptisch-hamitische Dekade. Zeitschrift für Ägyptische Sprache 67, 133-139.

Zyhlarz, Ernst. 1932-3. Ursprung und Sprachcharakter des Altägyptischen. Zeitschrift für Eingeborenen-Sprachen 23, 25-45, 81-110, 161-194, 241-254.

Zyhlarz, Ernst. 1934. Konkordanz ägyptischer und libyscher Verbalstammtypen. Zeitschrift für Ägyptische Sprache 70, 107-122.

Zyhlarz, Ernst. 1934-5. Die Sprachreste der unteräthiopischen Nachbarn Altägyptens. Zeitschrift für EingeborenenSprachen 25, 161-188, 241-261.

Zyhlarz, Ernst. 1950. Das kanarische Berberisch in seinem sprachgeschichtlichen Milieu. Zeitschrift der Deutschen Morgenländischen Gesellschaft 100, 403-460.

Габор Такач. Древнейшие лексические слои египетского языка VIII: числительные.

Статья продолжает серию публикаций автора, объединенных общей целью проанализировать древнейшие слои базисной лексики древнеегипетского языка, расклассифицированные по семантическим полям, и разделить их на «семитский» и «африканский» пласты, существование которых было предположено П. Лако несколько десятилетий тому назад. В данной статье анализу подвергаются числительные древнеегипетского языка.

Ключевые слова: древнеегипетский язык, афразийские (афроазиатские) языки, этимология, сравнительно-историческая фонетика, числительные. 
